\title{
SKRIPSI
}

\section{ANALISIS DEFECT RATE PENGELASAN DAN PENANGGULANGANNYA DENGAN METODE SIX SIGMA DAN FMEA DI PT. PROFAB INDONESIA}

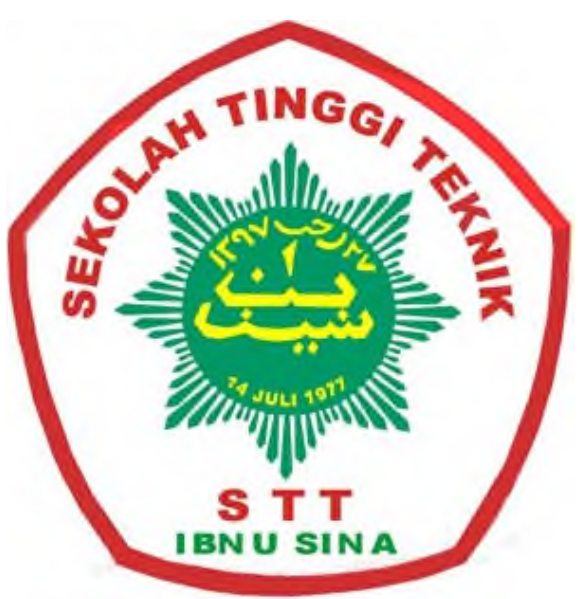

Skripsi ini Untuk Memperoleh Gelar Sarjana Teknik (ST.)

Pada Program Studi Teknik Industri Sekolah Tinggi Ibnu Sina Batam

DECKY ANTONY KIFTA 1210128425005

PROGRAM STUDI TEKNIK INDUSTRI SEKOLAH TINGGI TEKNIK IBNU SINA BATAM 2016 
HALAMAN PENGESAHAN PEMBIMBING

\section{ANALISIS DEFECT RATE PENGELASAN DAN \\ PENANGGULANGANNYA DENGAN METODE SIX SIGMA DAN \\ FMEA DI PT. PROFAB INDONESIA}

Skripsi telah disetujui pada tanggal: Agustus 2016

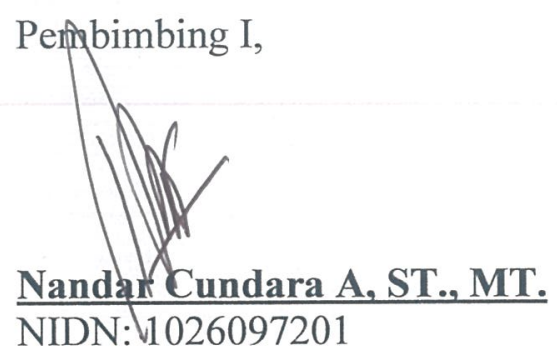

Ketua STT Ibnu Sina Batam

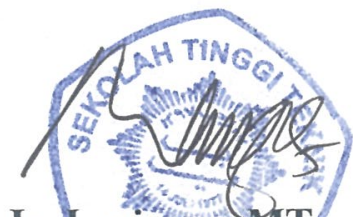

Ir. Larisang, MT

NIP: 196505132005011001

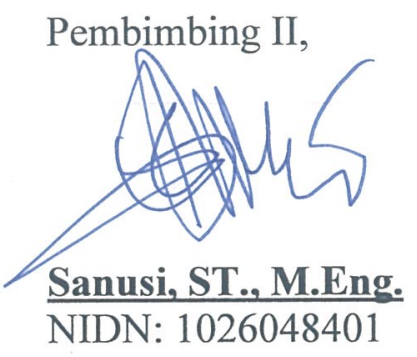

Mengetahui,
Napangulam syah, ST., MT.

NIDN: 1027068201 


\section{HALAMAN PENGESAHAN PERBAIKAN SKRIPSI}

Skripsi ini telah diuji, diperbaiki, diperiksa dan disetujui oleh panitia penguji

Program Studi Teknik Industri Sekolah Tinggi Teknik Ibnu Sina Batam Pada

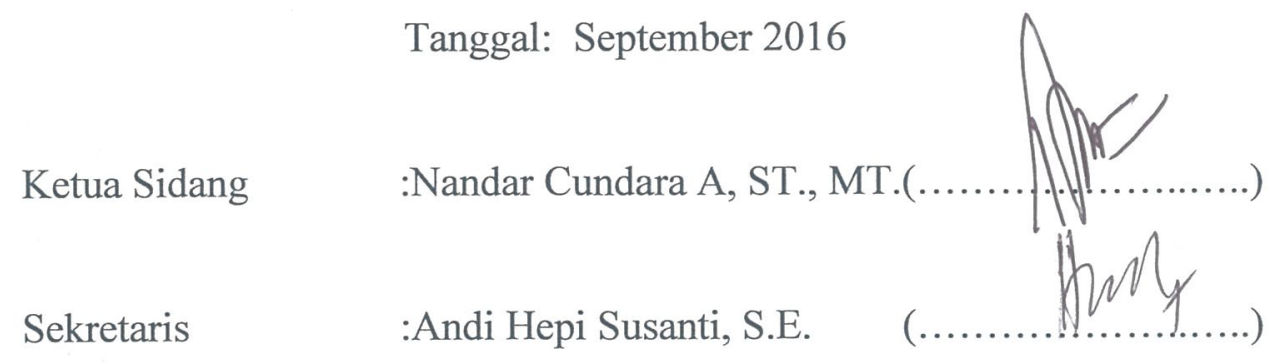

Dosen Penguji

1. M. Ansyar Bora, ST., MT.

2. Albertus Laurensius, ST., M.MT.

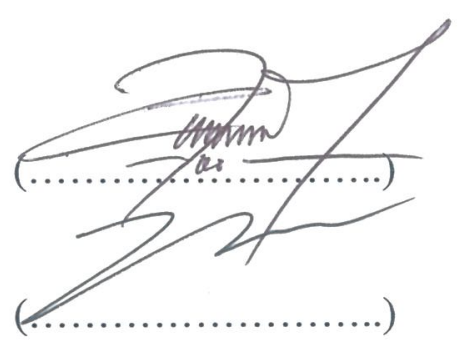

Pembimbing I,

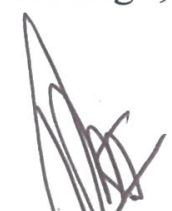

Nandar Cindara A, ST., MT.

NIDN: 1 Q26097201
Pembimbing II,

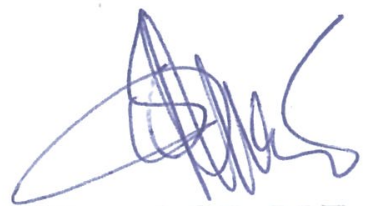

Sanusi, ST., M.Eng.

NIDN: 1026048401

Mengetahui,

Ketua STT Ibnu Sina Batam

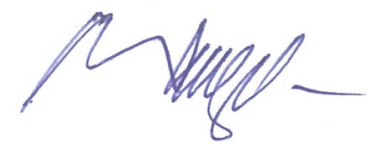

Ir. Larisang, MT. NIP: 196505132005011001
Ketua Program Studi Teknik Industri

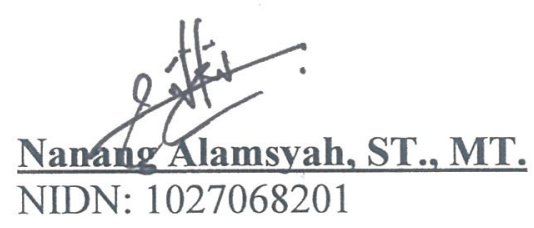




\section{HALAMAN PERNYATAAN}

Saya yang bertanda tangan di bawah ini:

Nama : Decky Antony Kifta

NPM : 1210128425005

Program Studi : Teknik Industri

Judul Skripsi : Analisis Defect Rate Pengelasan dan Penanggulangannya dengan Metode Six Sigma dan FMEA di PT Profab Indonesia.

Menyatakan bahwa skripsi yang saya buat adalah hasil tulisan saya sendiri. Dengan ini saya menyatakan dengan sesungguhnya bahwa dalam skripsi ini tidak terdapat keseluruhan atau sebagian tulisan orang lain yang saya ambil dengan cara menyalin atau meniru dalam bentuk rangkaian kalimat atau simbol yang menunjukkan gagasan atau pendapat atau pemikirin dari penulis lain, yang saya akui seolah-olah sebagai tulisan saya sendiri, dan / tidak terdapat bagian atau keseluruhan tulisan saya salin, tiru, atau yang saya ambil dari tulisan orang lain tanpa memberikan pengakuan penulis aslinya.

Apabila saya melakukan tindakan yang bertentangan dengan hal tersebut di atas, baik disengaja ataupun tidak, dengan ini saya menyatakan menarik skripsi yang saya ajukan sebagai hasil tulisan saya sendiri ini. Bila dikemudian hari terbukti bahwa saya melakukan tindakan menyalin atau meniru orang lain seolah-olah hasil pemikiran saya sendiri, berarti gelar dan ijazah saya yang telah diberikan oleh STT Ibnu Sina saya terima untuk dibatalkan.

Batam, Agustus 2016

Yang Membuat Pernyataan,

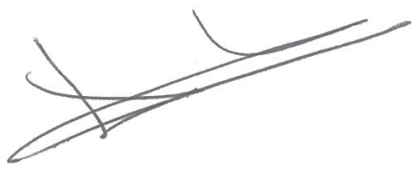

Decky Antony Kifta 


\title{
HALAMAN MOTTO DAN PERSEMBAHAN
}

\author{
Motto: \\ Sesungguhnya keberadaan manusia dibagi menjadi tiga bagian, \\ jika hari ini lebih baik dari hari kemarin maka dirinya beruntung, \\ jika hari ini sama dengan hari kemarin maka dirinya merugi, tetapi \\ jika hari ini lebih buruk dari hari kemarin maka dirinya termasuk \\ orang-orang yang celaka.
}

Quality is remembered long after price is forgotten (Aldo Gucci)

\section{Persembahan:}

Segala puji dan syukur dipanjantkan ke hadirat Tuhan Yang Maha Esa, Allah SWT, atas segala berkat, rahmat, hidayah, dan karunia-Nya yang selalu dicurahkan kepada semua hamba-Nya, serta shalawat dan salam dipanjatkan kepada junjungan besar Nabi Muhammad SAW sebagai penutup para nabi, dan

kepada ibu, istri dan anak-anak yang senantiasa mendukung dan memberi dorongan kepada penulis untuk memberikan yang terbaik lewat skripsi ini, serta kepada para dosen dan almamater Sekolah Tinggi Teknik Ibnu Sina, dan segenap manajemen PT Profab Indonesia yang telah membantu penulis dalam menyelesaikan skripsi ini. 


\begin{abstract}
ABSTRAK
Dalam rangka mencapai visi perusahaan yaitu untuk menjadikan PT Profab Indonesia sebagai perusahaan fabrikasi yang bertaraf internasional yang menghasilkan produk fabrikasi secara aman, berkualitas dan memenuhi persyaratan pelanggan namun tetap kompetitif dari segi harga, maka perusahaan berusaha mengupayakan sistem zero defect dalam produksi pengelasannya. Perusahaan juga memantau defect rate pengelasan dan mencoba menurunkan defect rate produksi pengelasan. Untuk menurunkan defect rate hingga mencapai zero defect maka perusahaan menerapkan metode Six Sigma dalam sistem produksi pengelasan.

Dengan menggunakan beberapa quality tools dimana salah satunya adalah FMEA maka perusahaan berhasil menurunkan defect rate dari $15,5 \%$ di bulan Oktober - Nopember 2015 menjadi 2,63\% di bulan Juni 2016. Hal ini juga sekaligus meningkatkan kinerja prosesnya yaitu dari rata-rata nilai Sigma 3,32 menjadi Sigma 4,10. Dengan menurunnya defect rate dan meningkatnya nilai Sigma memungkinkan perusahaan untuk terus berkembang dan mencapai sasaran mutu yang diinginkan yaitu kepuasan pelanggan.
\end{abstract}

Kata kunci: $\quad$ zero defect, defect rate, Six Sigma, quality tools dan FMEA. 


\begin{abstract}
In order to achieve the Company vision for PT Profab Indonesia to become a leading fabrication Company which is known internationally and produces safe and quality products, meeting Customer's requirements, however, still being competitive, therefore the Company tries to implement zero defect system in the welding production. The company monitors the defect rate and tries to minimize the welding defect rate. To minimize the defect rate to zero defect level the Company uses Six Sigma method in their welding production program.

In the using of quality tools which one of them is FMEA, the company reduce the defect rate from 15,5\% in the months of October - November 2015 to 2,63\% in month of June 2016. This also improves process performance from the average of sigma level 3,32 which is now becoming Sigma 4,0. With the decrease of repair rate and the increase of Sigma level will enable the company to keep growing and achieve the required quality objective which is customer satisfaction.
\end{abstract}

Key words: $\quad$ zero defect, defect rate, Six Sigma, quality tools, and FMEA. 


\section{KATA PENGANTAR}

Puji syukur penulis panjatkan kehadirat Allah SWT, yang telah memberikan rahmat, taufik serta hidayah-Nya kepada kita semua, sehingga pada kesempatan ini penulis dapat menyelesaikan laporan tugas akhir atau skripsi ini tepat pada waktunya.

Adapun skripsi ini disusun sebagai syarat memperoleh gelar Sarjana Teknik, dan isi dari skripsi ini penulis peroleh dari materi-materi perkuliahan dan dengan membaca pustaka-pustaka yang berkaitan dengan tema skripsi ini serta dengan mengadakan pengamatan langsung ke lapangan, di PT Profab Indonesia.

Pada kesempatan ini penulis mengucapkan terima kasih yang sebesar-besarnya kepada:

1. Bapak Ketua Yayasan Pendidikan Ibnu Sina, Bapak H. Andi Ibrahim, BA.,

2. Bapak Ketua STT Ibnu Sina, Bapak Ir. Larisang,

3. Bapak Pembantu Ketua I STT Ibnu Sina, Bapak Ansyar Bora, ST., MT.,

4. Bapak Ketua Prodi Teknik Industr, Bapak Nanang Alamsyah, ST., MT.,

5. Bapak Dosen Pembimbing I, Bapak Nandar Cundara A, ST., MT.,

6. Bapak Dosen Pembimbing II, Bapak Sanusi, ST, M.Eng.,

7. Bapak Koordinator Produksi PT. Profab Indonesia, Bapak Fatilah, ST.,

8. Seluruh Staff dan Mahasiswa Program Studi Teknik Industri STT Ibnu Sina,

9. Ibu, istri dan anak-anak saya tercinta,

atas bantuan dan bimbingannya sehingga penulis dapat menyelesaikan skripsi ini tepat pada waktunya.

Penulis menyadari bahwa skipsi ini masih banyak kekurangan, dan kesalahan serta masih jauh dari sempurna, oleh karena itu kritik dan saran yang sifatnya membangun sangat penulis harapkan.

Akhir kata penulis berharap semoga skripsi ini bermanfaat bagi kita semua.

Batam, Agustus 2016

Decky Antony Kifta

viii 


\section{DAFTAR ISI}

HALAMAN SAMPUL

HALAMAN PENGESAHAN PEMBIMBANG ...................................... ii

HALAMAN PENGESAHAN PERBAIKAN SKRIPSI ............................. iii

HALAMAN PERNYATAAN...............................................................iv

HALAMAN MOTTO DAN PERSEMBAHAN.........................................

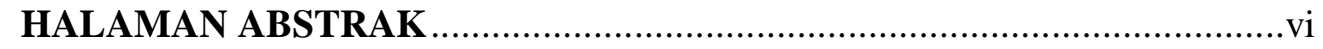

KATA PENGANTAR ........................................................................ vii

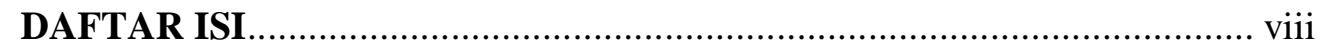

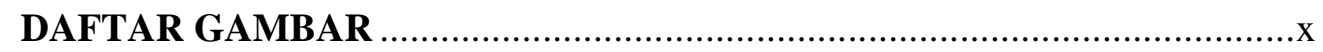

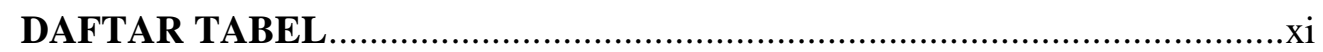

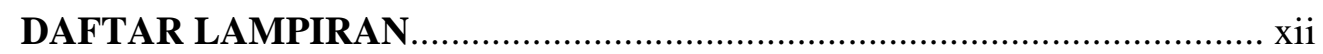

\section{BAB I PENDAHULUAN}

1.1 Latar Belakang ........................................................................... I-1

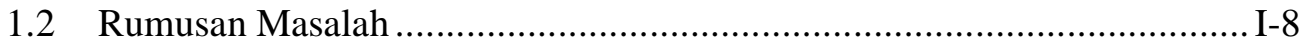

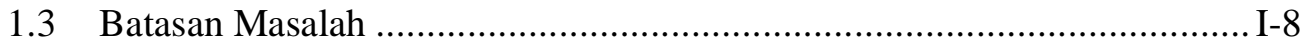

1.4 Tujuan Penelitian ............................................................................. I-8

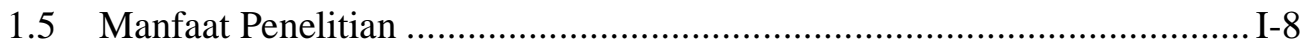

1.6 Sistematika Penulisan.......................................................................... I-8

BAB II TINJAUAN PUSTAKA

2.1 Landasan Teori .......................................................................................... II

2.2 Penelitian Terdahulu ......................................................................II-22

2.3 Kerangka Pikir......................................................................... 25

\section{BAB III METODOLOGI PENELITIAN}

3.1 Waktu dan Tempat Penelitian............................................................ III-1

3.2 Jenis Data.................................................................................... III -1

3.3 Populasi dan Sampel Penelitian .................................................. III-1

3.4 Variabel Penelitian dan Definisi Operasional....................................... III-2

3.5 Metode Pengumpulan Data..................................................................... III-3

3.6 Metode Pengolahan Data..................................................................... III-3 
3.7 Kerangka Pemecahan Masalah ......................................................... III-7

3.8 Jadwal Penelitian.........................................................................III-12

\section{BAB IV PENGOLAHAN DATA DAN PEMBAHASAN}

4.1 Mendefinisikan (Define) .............................................................. IV-1

4.2 Mengukur (Measure) ................................................................

4.3 Menganalisis (Analyze) ............................................................. IV-12

4.4 Meningkatkan (Improve) ….................................................... IV-17

4.5 Mengendalikan (Control) ....................................................... IV-29

BAB V PENUTUP

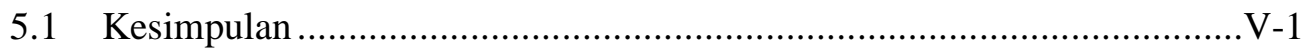

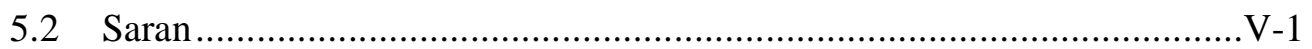

\section{DAFTAR PUSTAKA}




\section{DAFTAR GAMBAR}

Gambar 2.1 Contoh Check Sheet .................................................................6

Gambar 2.2 Contoh Diagram Fishbone ....................................................II-7

Gambar 2.3 Contoh Histogram .............................................................II-8

Gambar 2.4 Contoh Diagram Pareto .......................................................II-9

Gambar 2.5 Contoh Control Chart ..............................................................II-10

Gambar 2.6 Six Sigma Motorola ............................................................II-11

Gambar 2.7 Six Sigma Kualitas............................................................II-12

Gambar 2.8 Project Charter ................................................................

Gambar 2.9 Diagram Sebab-Akibat ....................................................II-17

Gambar 2.10 Six Sigma Kalkulator .....................................................II-21

Gambar 2.11 Kerangka Pikir ...................................................................II-26

Gambar 3.1 Diagram Alur Penelitian...................................................III-11

Gambar 3.2 Gantt Chart Penelitian dan Penyusunan Skripsi.........................III-13

Gambar 4.1 Time Series Plot dari Prosentase Defect bulan Juni 2016 ............. IV-3

Gambar 4.2 Diagram Jenis-Jenis Defect................................................. IV-3

Gambar 4.3 Diagram SIPOC Proses Pengelasan ....................................... IV-4

Gambar 4.4 Critical To Quality (CTQ) ................................................... IV-7

Gambar 4.5 Cause-Effect Diagram .................................................... IV-14 


\section{DAFTAR TABEL}

Tabel 1.1 Tabel Persentase Defect Pengelasan............................................. I-5

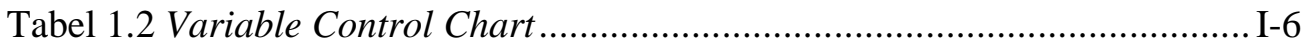

Tabel 1.3 Hubungan antara $C p$ dan Sigma Level ............................................ I-7

Tabel 1.4 Nilai Sigma, DPMO dan Peluang Tanpa Rusak............................... I-7

Tabel 2.1 Tabel Proporsi Defect Pengelasan ..............................................II-23

Tabel 2.2 Tabel Persentase Jenis Defect Pengelasan ...................................II-23

Tabel 2.3 Perhitungan Nilai Sigma ....................................................... II-24

Tabel 3.1 Analisis Tingkat Sigma dan DPMO......................................... III-5

Tabel 4.1 Data Jumlah Output dan Defect ............................................ IV-9

Tabel 4.2 Data Proporsi Defect Bulan Juni 2016.................................... IV-10

Tabel 4.3 Tabel Rekapitulasi Defect Bulan Juni 2016 ............................... IV-10

Tabel 4.4 Perhitungan Nilai Sigma .................................................. IV-11

Tabel 4.5 Analisis Jenis Defect .................................................................. IV-12

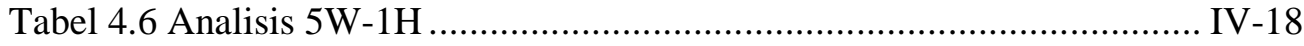

Tabel 4.7 Proses Kapabilitas.................................................................. IV-19

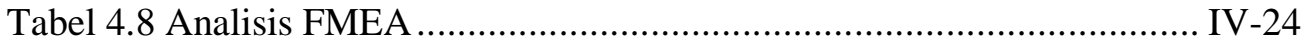




\section{DAFTAR LAMPIRAN}

Lampiran I.

Lampiran II.

Lampiran III.

Lampiran IV.

Lampiran V.

Lampiran VI

Lampiran VII.

Lampiran VIII.

Lampiran IX.
Critical to Quality

Repair Analysis Summary

Tabel FMEA

Bagan Organisasi Perusahaan

Production Flow Chart

Jenis-jenis Produk Perusahaan

Layout Perusahaan

On Time Delivery Charts

Tabel Konversi DPMO ke Nilai Sigma 


\section{BAB I \\ PENDAHULUAN}

\subsection{Latar Belakang}

\subsubsection{Umum}

Pertumbuhan industri manufaktur dunia semakin meningkat menuntut perusahaan untuk mampu bersaing melangsungkan pertumbuhan dan operasi perusahaan. Faktor terpenting yang akan dicapai perusahaan adalah keuntungan yang didapat dari hasil produksinya. Pencapaian efektifitas dan efisiensi perusahaan tentu menjadi dasar untuk mendapatkan keuntungan perusahaan.

Keuntungan perusahaan tentu tidak lepas dari peran manajemen untuk mempertahankan nilai jual produk dan kualitas sehingga pelanggan (customer) tidak berpindah kepada pesaing (competitor). Dalam kehidupan yang nyata pelanggan atau client cenderung memilih produk yang baik dari segi kualitas, harga yang ekonomis dan aspek-aspek lainnya. Pelanggan disebut juga raja karena dalam memilih produk, pelanggancenderung tidak mempedulikan bagaimana kondisi yang dihadapi perusahaan.

Langkah-langkah yang perlu dilakukan manajemen perusahaan adalah dengan menerapkan strategi-strategi untuk meningkatkan loyalitas pelanggan terhadap produk perusahaan, dimana tentunya hal ini dipengaruhi oleh kualitas produk dan layanan yang diberikan oleh perusahaan itu sendiri. Perhatian pada kualitas memberi dampak positif terhadap bisnis terutama pada biaya produksi dan pada pendapatan atau omset perusahaan.

Dampak biaya produksi terjadi melalui proses pembuatan produk yang memiliki kesesuaian (conformance) tinggi terhadap standar-standar yang dipakai sehingga kemungkinan kerusakan pada produk akan kecil atau dapat teratasi. Dampak terhadap peningkatan pendapatan perusahaan sehubungan dengan kualitas produk yang dapat diandalkan oleh pihak manajemen dan oleh pelanggan yang orientasinya adalah sebagai pengguna produk.

Perusahaan yang mengutamakan kualitas sebagai strategi andalan akan mempunyai nilai tambah tersendiri dibandingkan dengan pesaingnya dalam 
menguasai pasar. Proses produksi yang memperhatikan kualitas akan menghasilkan produk yang bebas cacat. Hal ini akan menghindari terjadinya pemborosanpemborosan dan ketidakefisiensianyang berdampak pada biaya produksi per unit dan tingkat kompetitif perusahaan. Sistem manajemen yang bertujuan mengurangi terjadinya pemborosan-pemborasan dan ketidakefisiensiankerja disebut juga sebagai Lean Management. Konsep lean adalah kumpulan pemahaman dan metode yang dirancang untuk mengeliminasi pemborosan (waste), mengurangi waktu tunggu (waiting time), memperbaiki kinerja (performance), dan mengurangi biaya produksi (Wahyuni, 2015: h.19).

Pada dasarnya penerapan sistem manajemen kualitas seperti Total Quality Management (TQM) menekankan pada upaya peningkatan serta perbaikan kualitas secara terus menerus berdasarkan kesadaran sendiri dari pihak manajemen.

PT Profab Indonesia adalah sebuah perusahaan industri manufaktur bejana tekan (pressure vessel) yang bergerak di bidang industri oil and gas (MIGAS) dan terdaftar di Direktorat Jendral Minyak dan Gas Negara Republik Indonesia dan telah memiliki sertifikat ISO 9001:2008 dan OHSAS 18001 dari TUV Rheinland. Dalam kegiatan produksinya PT Profab Indonesia menerapkan sistem produksi make to order/job shopdimana pekerjaan baru dilaksanakan apabila perusahaan mendapatkan order dari pelanggan.

Dalam proses manufaktur bejana tekan PT Profab Indonesia menggunakan proses pengelasan sebagai proses intinya selain dari pada proses-proses lain seperti pemotongan, rolling, pressing dan pengecatan (painting). Proses produksi dalam manufaktur bejana tekan dimulai dengan pembuatan desain tekan yang sesuai dengan standar dalam hal ini standar yang digunakan adalah standar internasional ASME VIII. Setelah desain selesai maka bagian purchasing akan membeli material sesuai dengan gambar desain. Bagian quality control akan mengecek material yang dipasok oleh supplier dan apabila material memenuhi persyaratan yang diminta, maka material akan diserahkan ke bagian produksi. Material kemudian dipotong sesuai gambar desain dan disambung atau dilakukan fit-up, setelah fit-up maka komponen akan siap untuk dilakukan pengelasan. 
Berdasarkan sistem produksi tersebut, PT Profab Indonesia harus menangani berbagai masalah mengenai kinerja kualitas produksi dan meminimalkan defect rate dari hasil pengelasan sebagai proses produksi. Setiap defect yang ditemui dari hasil non-destructive test (NDT) dengan menggunakan sarana film radiografi, dapat disebabkan oleh kesalahan manusia (juru las), mesin (mesin las), lingkungan kerja (cuaca, dan sebagainya), bahan baku (kawat las) ataupun metode kerja (proses pengelasan) yang digunakan oleh perusahaan.

Masalah yang timbul dari faktor-faktor tersebut akan berdampak pada pelanggan dan manajemen PT Profab Indonesia sendiri. Berdasarkan sistem manajemen kualitas (QMS) PT Profab Indonesia dan spesifikasi pelanggan bahwa maksimum defect rate yang dibolehkan pada pengelasan dengan inspeksitak merusak (NDT) dengan menggunakan film radiografi adalah 10\%, dengan rumus sebagai berikut:

$$
\% \text { defect }=\frac{\text { jumlah defect }}{\text { jumlah film RT yang dihasilkan (output) }}
$$

Hal ini memotivasi penulis untuk melakukan penelitian mengenai kinerja kualitas pengelasan di PT Profab Indonesia, terutama pada bagian pengelasan. Adapun alternatif penyelesaian masalah mengenai kualitas pengelasan yang juga mempengaruhi kualitas produk dapat dilakukan dengan analisis defect pengelasan dengan menggunakan metode Six Sigma.

Dengan metode pendekatan Six Sigma sebagai analisis defect pengelasandiharapkan departemen pengelasan pada bagian produksi dapat secepatnya mendapatkan penyebab utama tingginya cacat las dan mencoba mengusahakan perbaikan untuk mendapatkan hasil yang maksimal.

Pengendalian kualitas produk merupakan faktor yang sangat penting bagi dunia industri karena pengendalian kualitas yang baik dan dilakukan secara terus menerus akan dapat mendeteksi ketidaknormalan secara cepat, sehingga dapat segera dilakukan tindakan perbaikan dan antisipasinya. Hal ini juga untuk menjamin mutu produksi atau pelayanan perusahaan. Makin meningkatnya kemajuan proses produksi maka makin diperlukan pengendalian kualitas. Kontrol kualitas sangat diperlukan dalam memproduksi suatu produk dalam menjaga kestabilan mutu. 
Six Sigma sebagai salah satu metode baru yang paling populer merupakan salah satu alternatif dalam prinsip-prinsip pengendalian kualitas yang merupakan terobosan dalam bidang manajemen kualitas. Six Sigma dapat dijadikan ukuran kinerja sistem industri yang memungkinkan perusahaan melakukan peningkatan yang maksimal dan dengan terobosan strategi yang aktual.

Six Sigma juga dapat dipandang sebagai pengendalian proses produksi yang berfokus pada pelanggan dengan memperhatikan kemampuan proses. Pencapaian Six Sigma yaitu dengan hanya terdapat 3,4 cacat per sejuta kesempatan (defect per million opportunity-DPMO) memungkinkan perusahaan mencapai kondisi zero defect, suatu kondisi maksimal yang mungkin dicapai oleh perusahaan. Semakin tinggi target Sigma yang dicapai maka kinerja sistem industri semakin baik (Syukron, 2013: h.25). Harapan dari adanya kajian ini dapat menambah wacana pemahaman baik dari pabrik itu sendiri maupun pihak lain yang berkepentingan dalam penelitian ini.

Berdasarkan paparan latar belakang di atas maka penulis tertarik untuk melakukan penelitian tugas akhiratau skripsi dengan judul 'Analisis Defect Rate Pengelasan dan Penanggulangannya Dengan Metode Six Sigma dan FMEA di PT. Profab Indonesia', dan berdasarkan data laporan kerja praktek penulis sendiri yang dilakukan selama bulan Oktober dan Nopember 2015 di PT Profab Indonesia di departemen pengelasan memberikan data yang cukup kepada penulis untuk mengangkat masalah tersebut menjadi laporan tugas akhir atau skripsi penulis.

Berdasarkan penelitian sebelumnya yang dilakukan selama periode di atas di PT. Profab Indonesia didapati bahwa rata-rata defect rate perusahaan saat itu adalah 15,5\% dan nilai Sigma sebesar 3,32 dimana hal ini jauh di atas batas maksimum yang ditargetkan dalam KPI (Key Performance Indicator) perusahaan yaitu sebesar 10\%. Nilai Sigma yang ditargetkan oleh manajemen perusahaan sebagai kondisi ideal adalah sebesar minimum 4,0. Untuk itu maka perusahaan kemudian membentuk suatu tim Six Sigma yang diketuai oleh QA Manager PT Profab Indonesia. 


\subsubsection{Penentuan Process Capability $(\mathrm{Cp})$}

Process Capability $(C p)$ atau kemampuan proses berfungsi menilai kapabilitas atau kemampuan kinerja sebuah proses yang akan dicari nilai sigma-nya. Kapabilitas kinerja dapat diperoleh dengan menentukan USL (Upper Specification Limit) dan LSL (Lower Specification Limit). Dari data awal yang diperoleh peneliti pada saat Kuliah Praktek di PT Profab Indonesia pada bulan Oktober dan Nopember 2015 di dapat data bahwa nilai $C p$ sebesar 1,489 dan ketika dibandingkan dengan nilai $C p$ yang layak untuk dibuatkan proyek Six Sigmanya adalah 1,33. Jadi kesimpulannya hal ini berarti bahwa proses perhitungan defect rate tersebut layak untuk dihitung nilai sigma-nya.

\subsection{Perumusan Masalah}

Berdasarkan latar belakang di atas, maka permasalahan yang diangkat dalam penelitian ini diarahkan untuk mengatasi permasalahan dan bertujuan untuk menurunkan defect rate proses pengelasan yang tinggi pada in-process inspection dalam mencapai sasaran mutu perusahaan yaitu on time delivery.

\subsection{Batasan Masalah}

Untuk membatasi lingkup pembahasan agar sesuai dengan penelitian maka perlu dibuatkan batasan-batasan sebagai berikut:

1. Penelitian dilakukan di bagian pengelasan pada bagian produksipengelasan PT Profab Indonesia.

2. Analisis defect pengelasan ditinjau dari satuan film radiografi yang diperiksa setiap hari selama waktu penelitian.

3. Analisis defect pengelasan dengan menggunakan metode Six Sigma dan FMEA (Failure Mode and Effect Analysis) sebagai metode mencari mode kegagalan (failure mode).

\subsection{TujuanPenelitian}

Adapun tujuan penelitian yang akan dilakukan penulis yaitu menurunkan tingkat defect rate proses pengelasan yang tinggi dalam rangka mencapai on time delivery. 


\subsection{ManfaatPenelitian}

Meningkatkan output perusahaan dalam rangka mencapai KPI (key performance indicator) perusahaan berupa on time delivery.

\subsection{Sistematika Penulisan}

Untuk lebih memperjelas dan mengembangkan pokok-pokok pembahasan skripsi ini, maka dibuat sistematika penulisan skripsiyang antara lain adalah sebagai berikut:

\section{BAB I PENDAHULUAN}

Dalambab ini berisi pendahuluan yang membahas hal yang melatar belakangi penulis melakukan penelitian, rumusan masalah yang membahas hal-hal yang akan dibahas dalam penelitian, batasan masalah penelitian, tujuanpenelitian dan manfaat dilakukannyapenelitian, serta sistematika penulisan skripsi. Latar belakang penulisan yang berupa tingginya repair rate serta penanggulangannya di PT Profab Indonesia kemudian menjadi topik dari keseluruhan pembahasan skripsi ini.

\section{BAB II TINJAUAN PUSTAKA}

Pada bab ini dibahas mengenai landasan teori, yaitu teori-teori yang berhubungan dengan penelitian seperti definisi dari kualitas, dimensi kualitas, faktor-faktor yang mempengaruhi kualitas, tools of quality, diagram SIPOC (supplier, input, process, output, customer), pengertian Six Sigma, tahap-tahap pengendalian kualitas dengan metode Six Sigma, beberapa perhitungan yang berkaitan dengan DMAIC (Define, Measure, Analyse, Improve, and Control), dan FMEA.

\section{BAB III METODOLOGI PENELITIAN}

Dalam bab inidibahas mengenai waktu dan tempat penelitian, jenisjenis data, metode pengumpulan data, metode pengolahan data, tahapan perancangan, kerangka pemecahan masalah dan jadwal penelitian. 


\section{BAB IV PENGOLAHAN DATA DAN PEMBAHASAN}

Bab ini berisikan lima langkah Six Sigma yang biasa disebut dengan DMAIG yaitu mendefinisikan, mengukur, menganalisis, melakukan perbaikan dan mengendalikan. Penjabaran dan implementasi tahaptahap ini beserta data-data pendukungnya menjadi isi dari bab ini dan FMEA merupakan salah satu implementasi dari tahapan-tahapan analisis dan perbaikan.

\section{BAB V PENUTUP}

Bab ini merupakan kesimpulan dari penelitian atau skripsi ini dan berisikan rangkuman bagaimana metode yang diutarakan penulis dapat berguna bagi pembaca skripsi ini. Selain berisi kesimpulan, bab ini juga menuliskan saran-saran penulis untuk perbaikan-perbaikan kedepan.

\section{DAFTAR PUSTAKA}




\section{BAB II \\ TINJAUAN PUSTAKA}

\subsection{Landasan Teori}

\subsubsection{Kualitas}

Pengertian atau definisi dari kualitas mempunyai cakupan yang sangat luas, relatif, berbeda-beda dan berubah-ubah, sehingga definisi dari kualitas memiliki banyak kriteria dan sangat bergantung pada konteksnya terutama jika dilihat dari sisi penilaian akhir pelanggan (customer) dan definisi yang diberikan oleh berbagai ahli serta dari sudut pandang produsen sebagai pihak yang mengusahakan kualitas.

Baik konsumen dan produsen itu berbeda dan akan merasakan kualitas secara berbeda pula sesuai dengan standar kualitas yang dimiliki masing-masing. Begitu pula para ahli dalam memberikan definisi dari kualitas juga akan berbeda satu sama lain karena mereka membentuknya dalam dimensi yang berbeda. Oleh karena itu definisi kualitas dapat diartikan dari dua perspektif, yaitu dari sisi konsumen dan dari sisi produsen. Namun pada dasarnya konsep dari kualitas sering dianggap sebagai kesesuaian, keseluruhan ciri-ciri atau karakteristik suatu produk atau layanan yang diharapkan oleh konsumen dan memenuhi kebutuhannya.

Pengertian kualitas menurut Crosby (1979) adalah barang atau jasa yang memenuhi spesifikasi atau persyaratan pelanggan. Feigenbaum (1961) mendefinisikan bahwa kualitas merupakan keseluruhan karakteristik suatu produk (barang atau jasa) yang mampu memberikan kepuasan kepada pelanggan (Feigenbaum, 1986: h. 7). Bahkan Joseph Juran (1951) mempunyai suatu pendapat bahwa "quality is fitness for use" yang bila diterjemahkan secara bebas berarti bahwa kualitas atau mutu produk berkaitan dengan bagaimana produk tersebut dapat digunakan dengan baik (Wahyuni, 2015: h.4). Sedangkan Goetsch dan Davis (1994) mendefinisikan bahwa kualitas merupakan suatu kondisi dinamis yang berhubungan dengan produk (barang atau jasa), manusia, proses dan lingkungan yang memenuhi atau melebihi harapan pengguna (Tjiptono, 2003: h.4). 


\subsubsection{Dimensi Kualitas}

Secara umum, dimensi kualitas menurut Garvin (Tjiptono, 2003: h.27) adalah dengan cara mengidentifikasi delapan dimensi yang dapat digunakan untuk menganalisis karakteristik kualitas suatu produk, yaitu sebagai berikut:

1. Performansi (performance)

Berkaitan dengan aspek fungsional dari produk dan merupakan karakteristik utama yang dipertimbangkan oleh pelanggan ketika ingin membeli suatu produk.

2. Keistimewaan (features)

Merupakan aspek kedua dari kinerja yang menambah fungsi dasar, berkaitan dengan pilihan-pilihan dan pengembangannya.

3. Keandalan (reliability)

Berkaitan dengan kemungkinan suatu produk melaksanakan fungsinya sebagaimana diinginkan dalam periode waktu tertentu di bawah kondisi tertentu.

4. Kesesuaian (conformance)

Berkaitan dengan tingkat kesesuaian produk terhadap spesifikasi yang telah ditetapkan sebelumnya oleh pelanggan.

5. Daya tahan (durability)

Merupakan ukuran masa pakai suatu produk. Karakteristik ini berkaitan dengan daya tahan penggunaan produk.

6. Kemampuan pelayanan (seviceability)

Merupakan karakteristik yang berkaitan dengan kecepatan, keramahan, kesopanan, kompetensi, kemudahan serta akurasi dalam melakukan pelayanan.

7. Estetika (esthetics)

Merupakan karakteristik yang bersifat subyektif sehingga berkaitan dengan pertimbangan pribadi dan refleksi dari preferensi atau pilihan individu.

8. Kualitas yang dipersepsikan (perceived quality)

Bersifat subyektif, berkaitan dengan perasaan pelanggan dalam mempergunakan produk tersebut. 


\subsubsection{Faktor-faktor yang mempengaruhi kualitas}

Kualitas produk secara langsung dipengaruhi oleh sembilan bidang dasar atau 9M. Pada masa sekarang ada sejumlah besar kondisi yang membebani produksi melalui cara-cara yang tidak pernah terjadi dalam periode sebelumnya (Feigenbaum, 1986: h.59-60).

\section{Pasar (Market)}

Jumlah produk baru dan baik yang ditawarkan di pasar terus berkembang dengan laju yang eksplosif. Konsumen diarahkan untuk mempercayai bahwa ada produk baru yang dapat memenuhi hampir setiap kebutuhan. Pada masa sekarang konsumen dapat memperoleh produk yang lebih baik yang dapat memenuhi kebutuhan mereka. Pasar menjadi lebih besar ruang lingkupnya dan secara fungsional lebih terspesialisasi dalam barang yang ditawarkan. Dengan bertambahnya perusahaan, pasar menjadi bersifat internasional dan mendunia. Akhirnya bisnis harus lebih fleksibel dan mampu berubah arah dengan cepat.

2. Uang (Money)

Meningkatnya persaingan dalam banyak bidang industri bersamaan dengan fluktuasi ekonomi dunia, telah menurunkan batas (marjin) laba. Pada waktu yang bersamaan, kebutuhan akan otomasi dan mekanisasi mendorong pengeluaran yang besar untuk proses dan perlengkapan yang baru. Penambahan investasi pabrik, harus dibayar melalui naiknya produktivitas menimbulkan kerugian yang besar dalam berproduksi disebabkan oleh produk cacat dan pengulangan kerja yang sangat mahal. Kenyataan ini memfokuskan perhatian para manajer pada bidang biaya kualitas untuk mengatasi biaya operasi, meminimalkan kerugian, dan memperbaiki laba.

\section{Manajemen (Management)}

Tanggung jawab kualitas telah didistribusikan antara beberapa kelompok khusus. Sekarang bagian pemasaran melalui fungsi perencanaan produknya, harus membuat persyaratan produk. Bagian perancangan bertanggung jawab merancang produk yang akan memenuhi persyaratan tersebut. Bagian produksi mengembangkan dan memperbaiki kembali proses untuk memberikan kemampuan yang cukup dalam membuat produk sesuai dengan spesifikasi 
rancangan. Bagian pengendalian kualitas merencanakan pengukuran kualitas pada seluruh aliran proses yang menjamin bahwa hasil akhir memenuhi persyaratan kualitas produk atau pelayanan, setelah produk sampai pada konsumen dan menjadi bagian yang penting dari paket produk akhir. Hal ini telah menambah beban manajemen puncak, khususnya bertambahnya kesulitan dalam mengalokasikan tanggung jawab yang tepat untuk melakukan koreksi terhadap penyimpangan dari standar kualitas.

4. Manusia (Man)

Pertumbuhan yang cepat dalam pengetahuan teknis dan pengembangan bidangbidang baru seperti elektronika komputer menciptakan suatu permintaan yang besar akan pekerjaan dengan pengetahuan khusus. Pada waktu yang sama situasi ini menciptakan permintaan akan ahli teknik sistem yang akan mengajak semua bidang spesialisasi untuk bersama merencanakan, menciptakan dan mengoperasikan berbagai sistem yang akan menjamin suatu hasil yang diinginkan.

\section{Motivasi (Motivation)}

Penelitian tentang motivasi manusia menunjukkan bahwa sebagai hadiah tambahan selain uang, para pekerja masa kini juga memerlukan sesuatu yang memperkuat rasa keberhasilan di dalam pekerjaan mereka dan pengakuan bahwa mereka secara pribadi memberikan sumbangan untuk tercapainya tujuan perusahaan. Hal ini membimbing ke arah kebutuhan yang tidak ada sebelumnya yaitu pendidikan kualitas dan komunikasi yang lebih baik tentang kesadaran untuk bekerja sesuai standar.

\section{Bahan (Material)}

Disebabkan oleh biaya produksi dan persyaratan kualitas, para ahli teknik memilih bahan dengan batasan yang lebih baik daripada sebelumnya. Akibatnya spesifikasi bahan menjadi lebih ketat dan keanekaragaman bahan menjadi lebih besar. Namun bahan yang berkualitaslah yang diperlukan dalam proses produksi, karena barang atau material berkualitas rendah akan menghasilkan hasil produksi yang inferior atau di bawah standar.

7. Mesin dan Mekanisasi (Machine and Mechanization) 
Permintaan perusahaan untuk mencapai penurunan biaya dan volume produksi untuk memuaskan pelanggan telah mendorong penggunaan perlengkapan pabrik yang lebih rumit dan bergantung pada kualitas bahan yang diproses oleh mesin tersebut. Kualitas yang baik menjadi faktor yang kritis dalam memelihara waktu kerja mesin agar fasilitasnya dapat digunakan sepenuhnya.

8. Metode Informasi Mutakhir (Modern Information Method)

Evolusi teknologi komputer membuka kemungkinan untuk mengumpulkan, menyimpan, mengambil kembali, memanipulasi informasi pada skala yang tidak terbayangkan sebelumnya. Teknologi informasi yang baru ini menyediakan cara untuk mengendalikan mesin dan proses selama kegiatan produksi dan mengendalikan produk bahkan setelah produk sampai ke konsumen. Metode pemrosesan data yang baru dan konstan memberikan kemampuan untuk mengatur informasi yang bermanfaat, akurat, tepat waktu dan bersifat ramalan mendasari keputusan yang membimbing masa depan bisnis.

\section{Persyaratan Proses Produksi (Mounting Product Requirement)}

Kemajuan yang pesat dalam perancangan produk, memerlukan pengendalian yang lebih ketat pada seluruh proses pembuatan produk. Meningkatnya persyaratan persepsi yang lebih tinggi bagi produk menekankan pentingnya keamanan dan keterandalan produk.

\subsubsection{Tools of Quality}

Pakar kualitas W. Edwards Deming mengajukan cara pemecahan masalah melalui Statistical Process Control (SPC) atau Statistical Quality Control (SQC) yang dilandasi oleh tujuh alat statistik utama, yaitu check sheet, diagram sebab akibat, histogram, diagram pareto, run chart dan control chart, stratifikasi, dan scattered diagram (Tjiptono, 2003: h. 192).

Tidak semua dari tujuh alat statistik atau kualitas itu dipakai dalam penelitian ini, namun beberapa alat saja yang dipakai penulis dalam mendemonstrasikan hasilhasil penelitian. Penjelasan alat-alat kualitas yang digunakan dalam penelitian ini akan dijabarkan dalam dasar-dasar teori berikut:

1. Check sheet 
Check sheet atau tolly chart atau juga disebut lembar periksa merupakan alat bantu yang sederhana yang digunakan untuk membantu dan menghitung frekuensi dari suatu kejadian atau aktivitas, misalkan jumlah cacat suatu produk. Dengan check sheet (lihat Gambar 2.1) pengumpulan data dapat dipermudah dan dilakukan secara sistematis. Dari data check sheet ini maka kita dapat menyediakan yang diperlakukan data untuk alat bantu yang lain seperti diagram pareto dan sebagainya. Juga dengan alat bantu check sheet ini maka akan ditemukan jawaban dari pertanyaan how often is it wrong dan sebagainya.

\begin{tabular}{|c|c|c|c|c|c|c|c|}
\hline \multicolumn{8}{|c|}{ No of Defects Generated in the Factory - December 2011} \\
\hline Operator & Time & Machine 01 & Machine 02 & Machine 03 & Machine of & Total & \\
\hline \multirow{2}{*}{ A } & Morning & III & IIIII & 1 & /I & 10 & \multirow{2}{*}{24} \\
\hline & Evening & IIII & IIII & 1 & IIII & 14 & \\
\hline \multirow{2}{*}{ B } & Morning & 1 & /1 & & 1 & 4 & \multirow{2}{*}{10} \\
\hline & Evening & /l & /I & I & 1 & 6 & \\
\hline \multirow{2}{*}{ c } & Morning & & 1 & & 1 & 2 & \multirow{2}{*}{5} \\
\hline & Evening & 1 & 1 & & 1 & 3 & \\
\hline \multirow[t]{2}{*}{ D } & Morning & "I & III & "I & I & 8 & \multirow{2}{*}{19} \\
\hline & Evening & III & III & III & "I & 11 & \\
\hline & Iotal & 16 & 21 & & 13 & 58 & \\
\hline
\end{tabular}

Gambar 2.1 Contoh Check Sheet

2. Diagram sebab akibat (cause and effect diagram)

Diagram sebab akibat merupakan teknik untuk mengidentifikasi kemungkinan penyebab-penyebab dari suatu masalah. Diagram ini membantu dalam memecahkan suatu masalah dan fokus pada akar utama penyebab masalah itu sendiri. Dengan alat bantu ini maka kita akan dapat menjawab pertanyaan what cause the problem, karena bentuk diagram menyerupai tulang ikan maka diagram ini sering disebut juga sebagai fishbone diagram (lihat Gambar 2.2). 


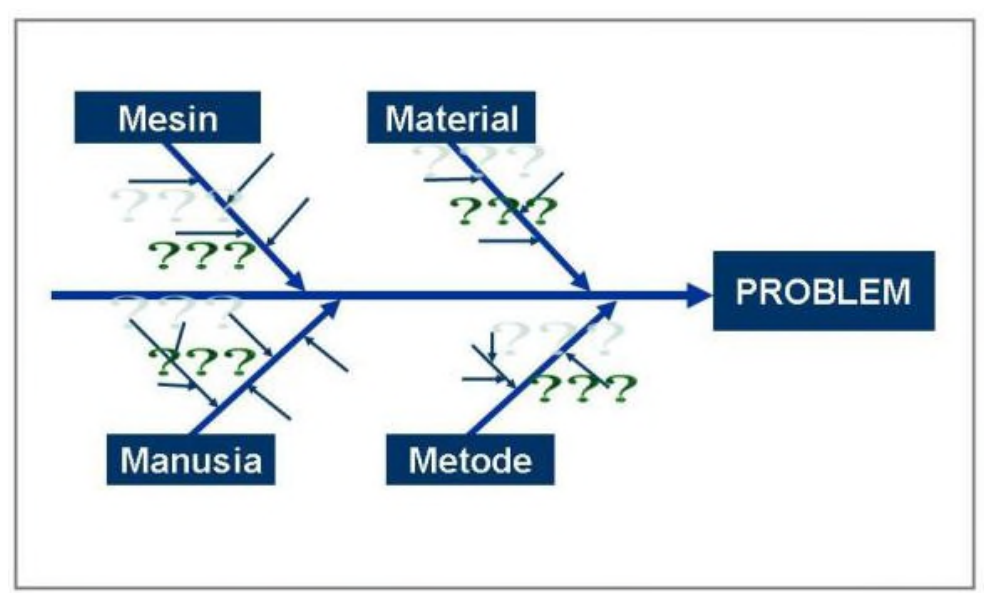

Gambar 2.2 Contoh Diagram Fishbone

Diagram sebab akibat ini pada umumnya mendefinisikan lima kategori penyebab yaitu sebagai berikut:

a) Material

Bahan baku yang digunakan dalam proses produksi (barang atau jasa) biasanya juga berupa informasi atau data dari semua jenis bahan yang digunakan.

b) Metode

Prosedur, instruksi kerja atau cara manusia untuk menyelesaikan pekerjaannya, juga termasuk cara pengukuran terhadap kualitas, seperti dengan cara inspeksi atau pengujian.

c) Mesin

Semua jenis perlengkapan dan peralatan yang digunakan.

d) Manusia

Semua sumber daya manusia yang ikut dalam proses tersebut, termasuk juga pelanggan, pemasok, pengusaha, pemerintah, karyawan, pemilik saham, masyarakat sekitar dan sebagainya.

e) Lingkungan

Lingkungan fisik dan suasana kerja atau lingkungan manajemen (psikis). Lingkungan juga sangat mempengaruhi kinerja pekerja atau karyawan, kondisi kerja yang nyaman dan kondusif akan menghasilkan kinerja yang baik.

\section{Histogram}


Histogram adalah alat bantu statistik yang memberi gambaran suatu proses dari sebuah operasi pada suatu waktu. Pertama kali digunakan oleh Karl Person pada tahun 1895 untuk memetakan distribusi frekuensi yang terjadi pada tiap kategori penelitiannya. Histogram (lihat Gambar 2.3) dapat berupa sebuah grafik batang yang menunjukkan frekuensi data yang memberikan cara yang paling mudah untuk mengevaluasi distribusi data.

Histogram of Data

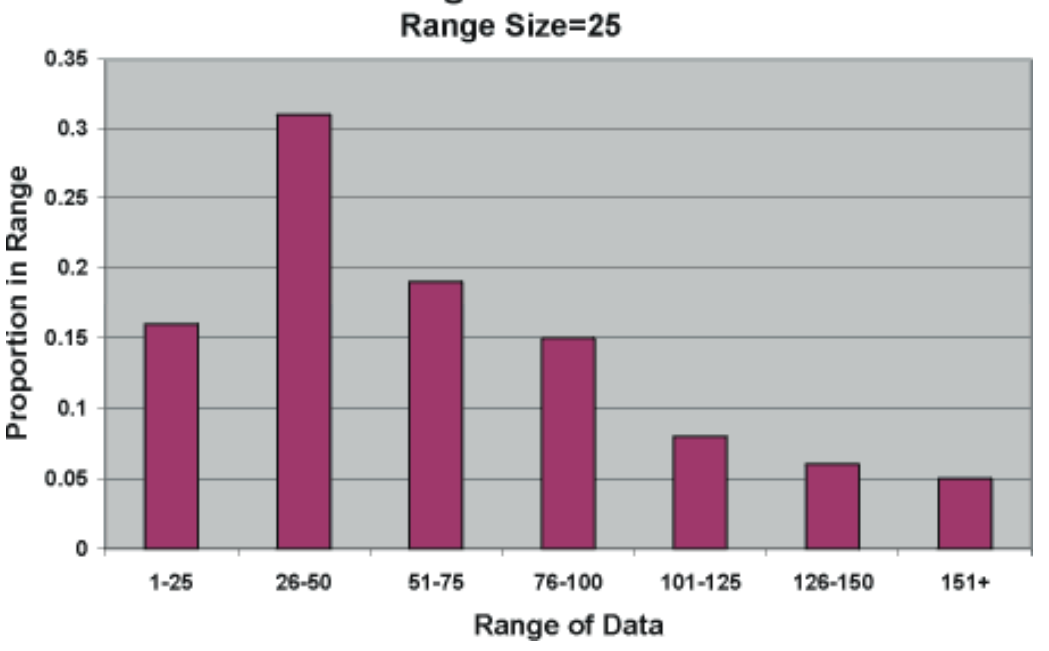

Gambar 2.3 Contoh Histogram

\section{Diagram Pareto}

Menurut Vilfredo Pareto atau dikenal dengan aturan Pareto yang berbunyi bahwa delapan puluh persen dari kesulitan yang dialami disebabkan oleh dua puluh persen masalah atau $20 \%$ produk cacat menyebabkan $80 \%$ masalah (Tjiptono, 2003: h.54). Dengan diagram Pareto ini (lihat Gambar 2.4) kita dapat melihat komponen-komponen apa saja yang bobotnya paling besar sampai yang terkecil dari masalah yang kita amati. 


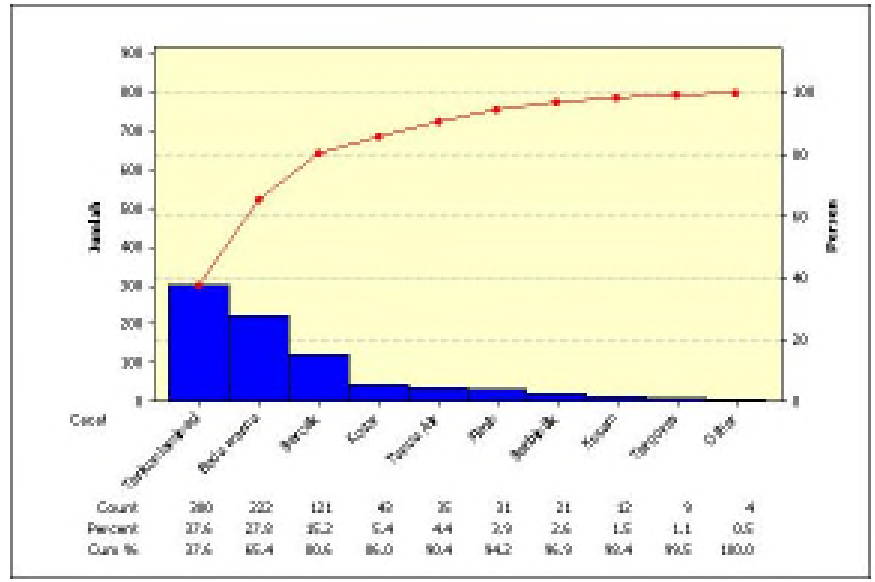

Gambar 2.4 Contoh Diagram Pareto

Analisis pareto merupakan teknik dalam merekam data dan menganalisis informasi dalam hubungannya antara permasalahan dan penyebabnya. Dengan diagram ini kita dapat mengidentifikasi aspek paling signifikan dari penyebab masalah sehingga dapat menjawab pertanyaan 'what is the biggest problem'.

\section{Control chart}

Control chart merupakan alat yang dapat menvisualisasikan variasi-variasi yang terjadi pada kecenderungan dan penyebaran pusat dari suatu kumpulan observasi sehingga suatu proses dapat dimonitor dan dikendalikan. Control chart (lihat Gambar 2.5) terdiri dari garis pusat yang menggambarkan nilai rata-rata dan sepasang batas kendali yang masing-masing diletakkan di bawah dan di atas garis pusat. Jika semua nilai yang digambarkan berada dalam batas kendali tanpa terjadi kecenderungan khusus maka proses dianggap masih dalam keadaan terkendali. Jika nilai yang digambarkan berada di luar batas kendali maka proses dianggap menjadi tidak terkendali.

Ada dua jenis control chart yaitu variable control chart dan attribute control chart. Variable control chart menggunakan data yang dapat diukur, sedangkan attribute control chart menggunakan data yang tidak dapat diukur. Jenis variable control chart adalah $X$-Bar chart, $R$ chart dan $S$ chart, sedangkan jenis attribute control chart yaitu $p$ chart, $n p$ chart, $c$ chart dan $u$ chart. 


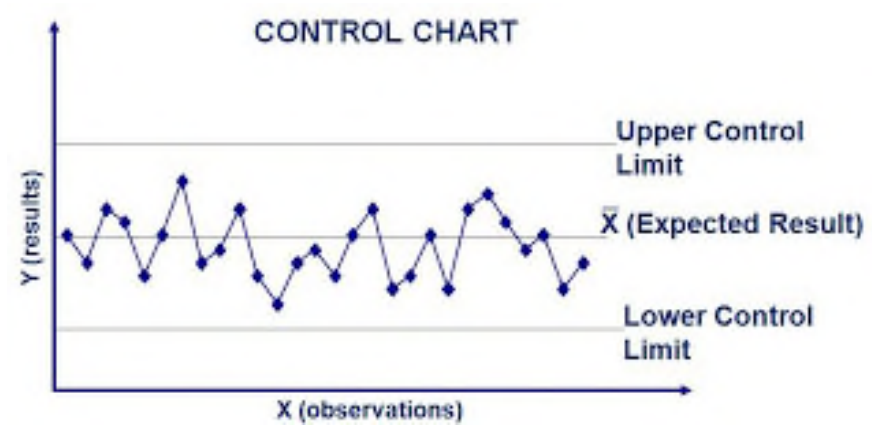

Gambar 2.5 Contoh Control Chart

\subsubsection{Diagram SIPOC}

Diagram SIPOC (supplier, input, process, output, customer) merupakan suatu alat kualitas yang berguna dan paling banyak digunakan dalam manajemen dan dalam usaha peningkatan proses. Diagram SIPOC adalah suatu sistem integrasi rantai produksi yang dimulai dari pemasok (supplier) bahan baku sampai jadinya suatu produk akhir dan diterima oleh pelanggan (customer). Diagram ini digunakan untuk menyajikan tampilan sekilas dari aliran kerja. SIPOC berasal dari lima elemen yang ada pada diagram yaitu (Pande, 2003: h. 179):

\section{Supplier}

Supplier (pemasok) merupakan orang atau sekelompok orang yang memberi informasi kunci, bahan-bahan atau sumber daya lainnya, kepada process.

\section{Input}

Input merupakan segala sesuatu yang diberikan oleh supplier (pemasok).

\section{Process}

Process adalah sekumpulan langkah yang mengubah, atau idealnya menambah nilai dari input. Suatu proses dapat terdiri dari beberapa sub-proses.

\section{Output}

Output adalah hasil akhir dari suatu proses, output merupakan produk yang dapat berupa barang atau jasa. Dalam industri manufaktur output dapat berupa barang jadi atau setengah jadi dan dapat juga menjadi input dari proses selanjutnya.

\section{Customer}

Customer atau pelanggan adalah orang atau kelompok orang, atau proses, yang menerima atau menggunakan output. 


\subsubsection{Pengertian Six Sigma}

Menurut Montgomery (Montgomery, 2009: h. 28-29) bahwa pada awalnya ada dua jenis program Six Sigma yang dipakai dalam dunia industri yaitu Six Sigma program Motorola dan Six Sigma program kualitas. Six Sigma program Motorala, dikembangkan oleh Motorola di tahun 1980an menggunakan Six Sigma yang diperoleh dari kurva distribusi normal yang berpusat pada target atau nilai mean (lihat gambar 2.6), sedangkan Six Sigma program kualitas menggunakan kurva distribusi normal dengan rata-rata yang bergeser sebesar $\pm 1,5$ sigma dari target atau nilai nominal (lihat gambar 2.7). Six sigma program Motorola menghasilkan limit hingga 2 parts per billion defectives atau 2 bagian per milyar kegagalan atau 0,002 ppm (parts per million) kegagalan. Sedangkan Six Sigma kualitas (lihat Gambar 2.7) hanya menkonsiderasikan 3,4 bagian per juta kegagalan atau 3,4 ppm kegagalan.

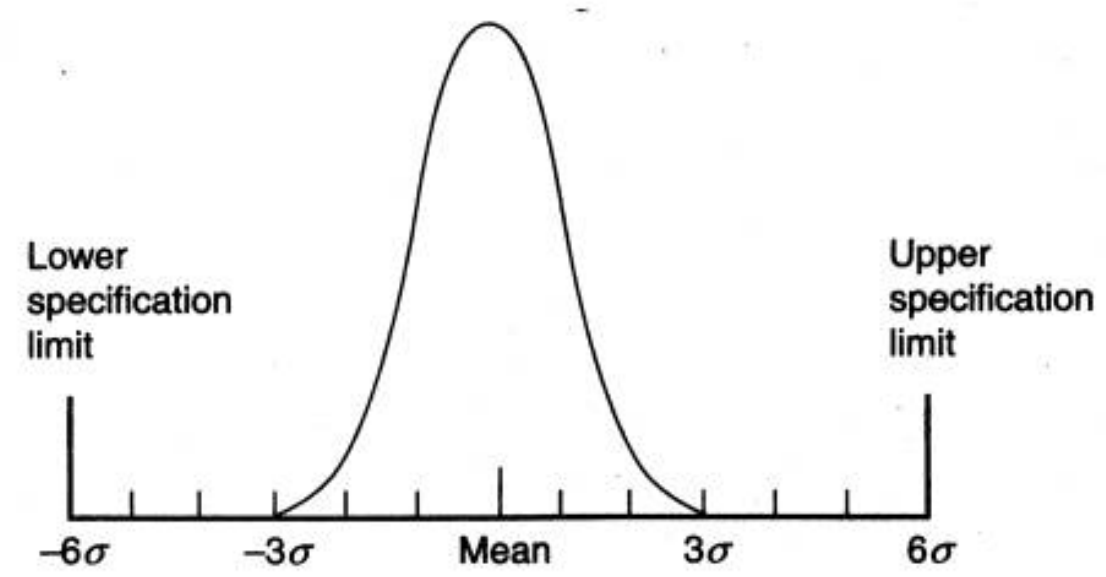

Gambar 2.6 Six Sigma Motorola 


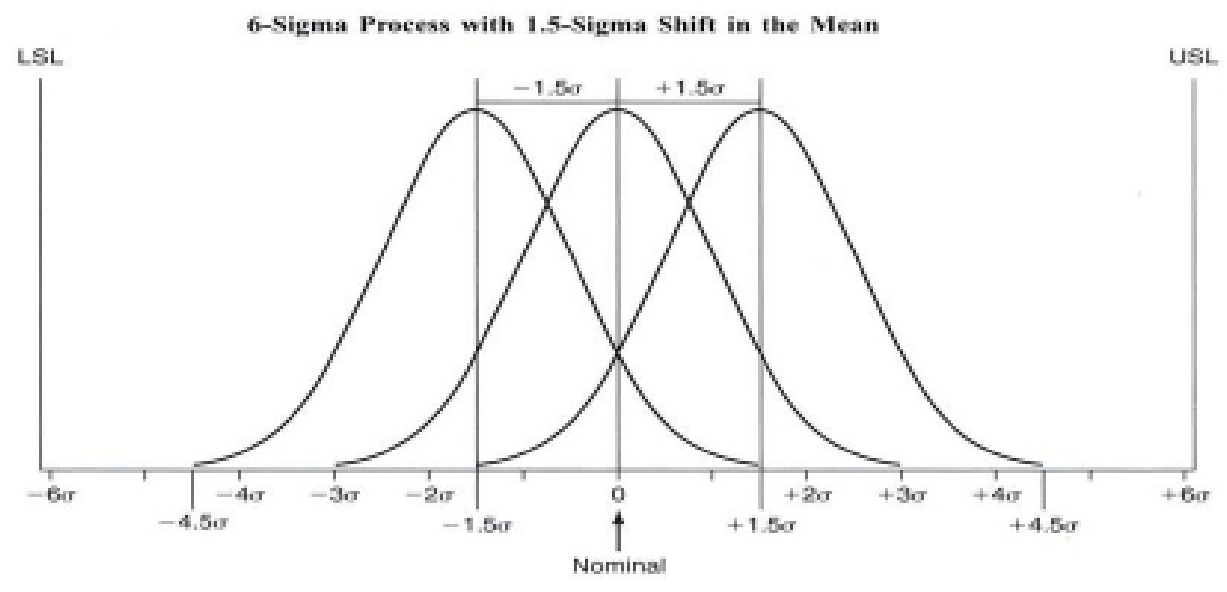

Gambar 2.7 Six Sigma Kualitas

Six Sigma memiliki arti yaitu tujuan yang hampir sempurna dalam memenuhi persyaratan pelanggan. Pada dasarnya, definisi ini juga akurat karena istilah Six Sigma sendiri merujuk kepada target kinerja operasi yang diukur secara statistik dengan hanya 3,4 cacat (defect) untuk setiap juta aktivitas atau peluang/kesempatan (Pande, 2003: h.82). Jadi Six Sigma merupakan metode atau teknik pengendalian dan peningkatan kualitas dramatis yang merupakan terobosan baru dalam bidang manajemen kualitas.

Pada dasarnya pelanggan akan merasa puas apabila mereka menerima nilai yang diharapkan. Apabila produk diproses pada tingkat kualitas Six Sigma, maka perusahaan boleh mengharapkan bahwa 99,99966\% dari apa yang diharapkan pelanggan akan ada dalam produk itu.

Menurut Pande terdapat lima langkah dasar yang perlu diperhatikan dalam penerapan konsep Six Sigma, yaitu (Pande, 2003: h. 84):

1. Mengidentifikasi proses-proses inti dan para pelanggan kunci.

2. Menentukan persyaratan pelanggan.

3. Mengukur kinerja saat ini.

4. Memprioritaskan, menganalisis, dan mengimplementasikan perbaikan.

5. Mengelola proses-proses untuk kinerja Six Sigma. 
Selanjutnya Gasperz (Gazperz, 2001) menambahkan apabila konsep Six Sigma akan diterapkan dalam proses manufaktur, terdapat enam aspek yang perlu diperhatikan yaitu:

1. Identifikasi karakter produk yang memuaskan pelanggan (yaitu yang sesuai kebutuhan dan ekspektasi pelanggan).

2. Mengklasifikasikan semua karakteristik kualitas atau CTQ (Critical To Quality) secara individu.

3. Menentukan apakah setiap CTQ tersebut dapat dikendalikan melalui pengendalian material, mesin proses kerja dan lain-lain.

4. Menentukan batas maksimum toleransi untuk setiap CTQ sesuai dengan yang diinginkan pelanggan (menentukan nilai batas kendali atas dan batas kendali bawah dari setiap CTQ).

5. Menentukan maksimum variasi proses untuk setiap CTQ (menentukan nilai minimum standar deviasi untuk setiap CTQ).

6. Mengubah desain produk dan/atau proses sedemikian rupa agar mampu mencapai nilai target Six Sigma.

\subsubsection{Tahap-tahap Implementasi}

Menurut Syukron (Syukron, 2013: h. 27-29) bahwa six sigma memerlukan tahapan implementasi, dan tahapan itu terdiri lima langkah yaitu menggunakan metode DMAIC atau Define, Measure, Analyse, Improve and Control.

\section{Menetapkan (Define)}

Langkah awal dalam pelaksanaan metodologi Six Sigma adalah proses define, dimana manajemen perusahaan yaitu pimpinan perusahaan harus mengidentifikasi secara jelas problem-problem yang dihadapi. Kedua, memilih sebuah tindakan alternatif sebagai proyek yang dapat menyelesaikan problem atau mencegah meluasnya problem. Ketiga, perusahaan perlu merumuskan parameter keberhasilan proyek yang ditetapkan, menyangkut luasnya masalah, sasaransasaran yang akan dicapai, sumber daya yang tersedia dan biaya yang akan timbul. Juga menurut Muis (Muis, 2014: h.6) bahwa ada tiga bagian utama yang berkaitan dengan mendefinisikan proses peningkatkan kualitas six sigma adalah: 
a) Membuat dan menginisial project charter.

b) Melakukan analisis SIPOC.

c) Menganalisis VoC (Voice of Customer).

Yang dimaksud dengan project charter adalah pernyataan-pernyataan tentang masalah, tujuan, cakupan proyek, jadwal pelaksanaan, keuntungan dan biaya proyek (lihat Gambar 2.8).

\section{Project Registration}

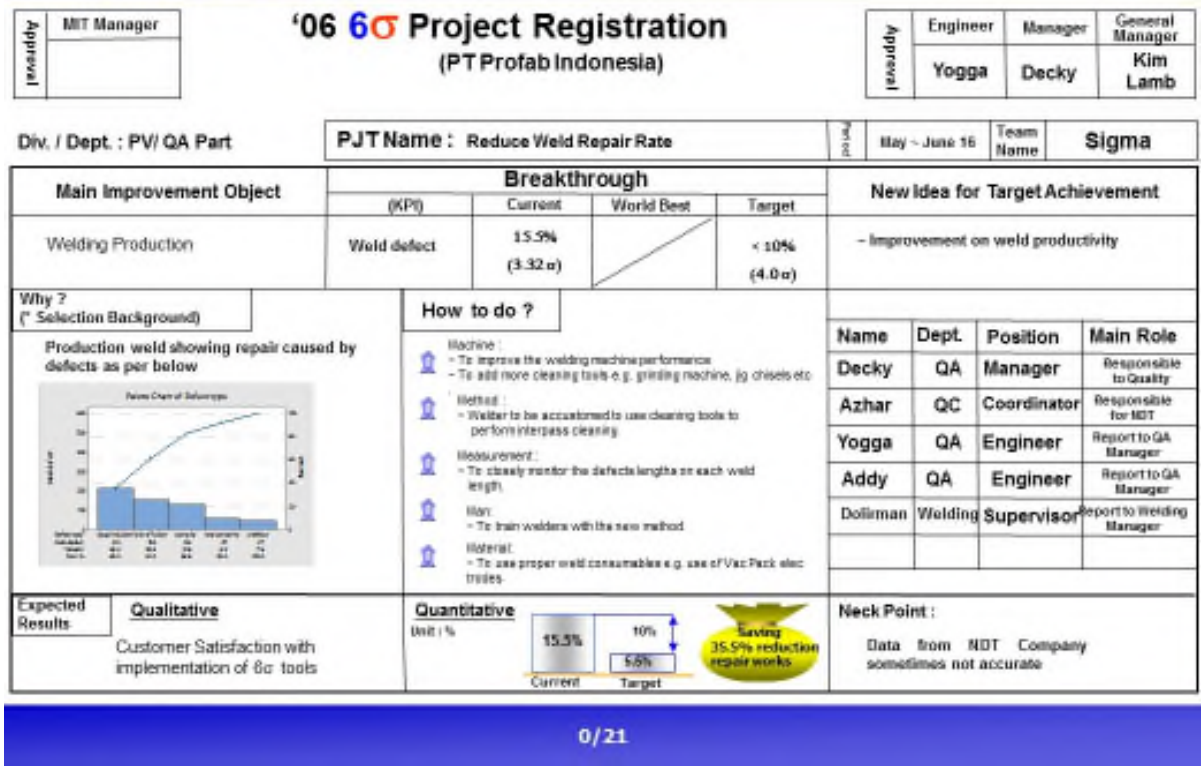

Gambar 2.8. Project Charter

Untuk itu, dalam setiap proyek Six Sigma kita harus mendefinisikan dan menentukan sasaran dan tujuan proyek. Tujuan tersebut harus spesifik, dapat diukur (measurable), mencapai target kualitas yang diinginkan (result oriented) dan mempunyai waktu yang tertentu (time limit).

\section{Mengukur (Measure)}

Pada tahap ini, terlebih dahulu manajemen harus memahami proses internal perusahaan yang sangat potensial mempengaruhi mutu output, atau yang disebut juga sebagai critical to quality (CTQ). Kemudian mengukur besaran penyimpangan yang terjadi dibandingkan dengan standar mutu yang telah ditetapkan pada CTQ. Artinya dalam tahap ini kita harus mengetahui kegagalan atau cacat yang terjadi dalam produk atau proses yang akan kita perbaiki. Jadi 
secara umum tahap measure bertujuan untuk mengetahui CTQ dari produk atau proses yang akan kita perbaiki, selanjutnya mengumpulkan beberapa informasi dari produk atau proses, dan mulai menerapkan target perbaikan yang akan dilakukan.

Dalam tahapan measure ini juga terdapat tiga hal pokok yang harus dilakukan, yaitu:

a) Memilih atau menentukan karakteristik kualitas yang utama atau CTQ utama/kunci. Penentuan CTQ utama harus disertai dengan pengukuran yang dapat dikuantifikasikan dalam angka-angka. Hal ini bertujuan agar tidak menimbulkan persepsi dan interpretasi yang dapat saja salah bagi setiap orang yang terlibat dalam proyek Six Sigma dan menimbulkan kesulitan dalam pengukuran karakteristik kualitas keandalannya. Dalam mengukur karakteristik kualitas, perlu diperhatikan aspek internal (tingkat kecacatan produk, biaya-biaya sebagai akibat kegiatan pengerjaan-ulang/perbaikan dan lain-lain sebagainya) dan aspek eksternal organisasi (seperti kepuasan pelanggan, pangsa pasar dan lain-lain).

b) Mengembangkan rencana pengumpulan data

Pengukuran karakteristik kualitas dapat dilakukan pada tingkat, yaitu:

1) Pengukuran pada tingkat proses (process level)

Mengukur setiap langkah atau aktivitas dalam proses dan karakteristik kualitas input yang diserahkan oleh pemasok (supplier) yang mengendalikan dan mempengaruhi karakteristik kualitas output yang diinginkan.

2) Pengukuran tingkat output (output level)

Mengukur karakteristik kualitas output yang dihasilkan dari suatu proses dibandingkan dengan spesifikasi karakteristik kualitas yang diinginkan oleh pelanggan. Pengukuran tingkat output ini dimaksudkan untuk mengetahui sejauh mana output akhir tersebut dapat memenuhi kebutuhan spesifik pelanggan sebelum produk tersebut diserahkan kepada pelanggan.

3) Pengukuran pada tingkat hasil (outcome level) 
Mengukur bagaimana baiknya suatu produk (barang atau jasa) apakah produk tersebut memenuhi kebutuhan spesifik dan ekspektasi rasional dari pelanggan.

c) Pengukuran baseline kinerja pada tingkat output

Kerena proyek peningkatan kualitas Six Sigma yang ditetapkan akan difokuskan pada upaya peningkatan kualitas menuju ke arah zero defect sehingga memberikan kepuasan total kepada pelanggan, maka sebelum proyek dimulai, kita harus mengetahui tingkat kinerja yang sekarang atau dalam terminologi Six Sigma disebut sebagai tingkat kinerja baseline (baseline performance), sehingga kemajuan peningkatan yang dicapai setelah memulai proyek Six Sigma dapat diukur dan seterusnya dimonitor selama proyek berlangsung.

\section{Menganalisis (Analyze)}

Merupakan langkah operasional yang ketiga dalam program peningkatan kualitas Six Sigma. Ada beberapa hal yang harus dilakukan pada tahap ini yaitu:

a) Menentukan stabilitas dan kapabilitas/kemampuan proses

Proses industri dipandang sebagai suatu peningkatan terus menerus (continuous improvement) yang dimulai dari sederet siklus sejak adanya ideide untuk menghasilkan suatu produk (barang atau jasa), pengembangan produk, proses produksi/operasi, sampai kepada distribusi kepada pelanggan. Target Six Sigma adalah membawa proses industri yang memiliki stabilitas dan kemampuan sehingga mencapai zero defect. Dalam menentukan apakah suatu proses berada dalam kondisi stabil dan mampu akan dibutuhkan alat-alat statistik sebagai sarana analisis. Pemahaman yang baik tentang metode-metode statistik dan perilaku proses industri akan meningkatkan kinerja sistem industri secara terus-menerus menuju tercapainya zero defect.

b) Menetapkan target kinerja dari karakteristik kualitas (CTQ) kunci Secara konseptual, penetapan target kinerja dalam proyek peningkatan kualitas Six Sigma merupakan hal yang sangat penting dan harus mengikuti prinsip SMART, yaitu sebagai berikut: 
1) Specific, yaitu target kinerja dalam proyek peningkatan kualitas Six Sigma harus bersifat spesifik dan dinyatakan secara tegas.

2) Measureable, target kinerja dalam proyek peningkatan kualitas Six Sigma harus dapat diukur menggunakan indikator pengukuran (matriks) yang tepat, guna mengevaluasi keberhasilan, peninjauan ulang, dan tindakan perbaikan di waktu mendatang.

3) Achievable, target kinerja dalam proyek peningkatan kualitas Six Sigma harus dapat dicapai melalui usaha-usaha yang menantang (challenging efforts).

4) Results-oriented, target kinerja dalam proyek peningkatan Six Sigma harus berfokus pada hasil-hasil berupa peningkatan kinerja yang telah didefinisikan dan ditetapkan sebelumnya.

5) Time-bound, target kinerja dalam proyek peningkatan Six Sigma harus menetapkan batas waktu pencapaian target kinerja dari setiap karakteristik kualitas (CTQ).

c) Mengidentifikasi sumber-sumber dan akar penyebab masalah kualitas.

Untuk mengidentifikasi masalah dan menemukan sumber penyebab masalah kualitas, digunakan alat analisis diagram sebab akibat (lihat Gambar 2.8) atau diagram tulang ikan. Diagram ini membentuk cara-cara membuat produkproduk yang lebih baik dan mencapai hasilnya.

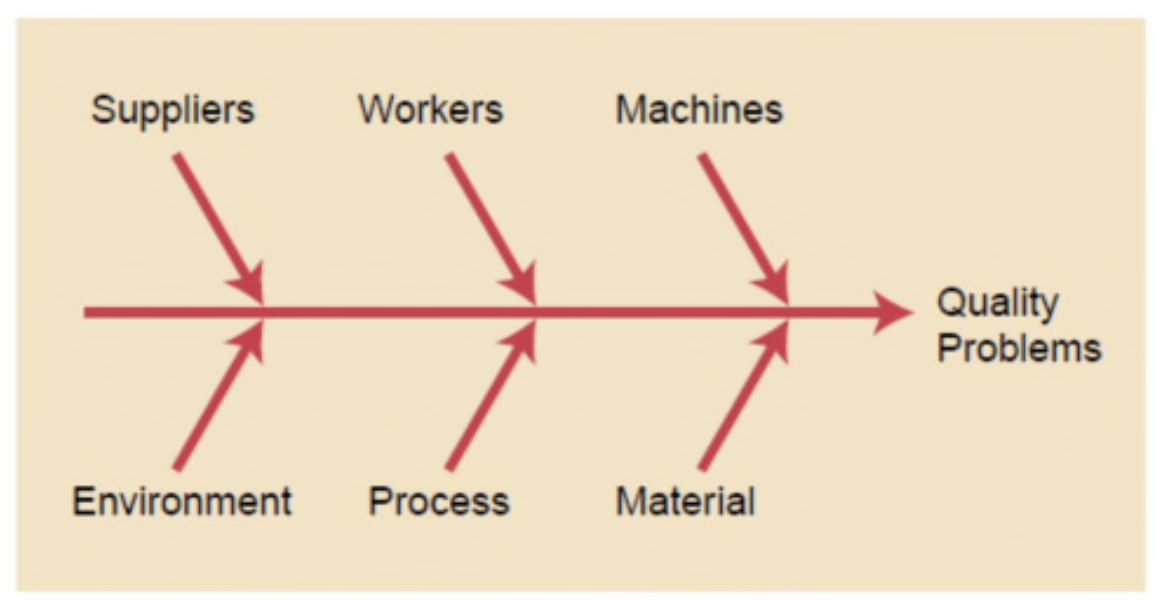

Gambar 2.9 Diagram Sebab-Akibat 
Sunber penyebab masalah kualitas yang ditemukan berdasarkan prinsip 7M, yaitu (Gaspersz, 2001) :

1) Manpower (tenaga kerja), berkaitan dengan kekurangan dalam pengetahuan, kekurangan dalam ketrampilan dasar, akibat lain yang berkaitan dengan mental dan fisik, kelelahan, stres, ketidakpedulian, dan lain-lain.

2) Machines (mesin dan peralatan), berkaitan dengan tidak ada sistem perawatan preventif terhadap mesin dan peralatan produksi, termasuk fasilitas dan peralatan lain tidak sesuai dengan spesifikasi tugas, tidak dikalibrasi, terlalu rumit, terlalu panas, dan lain-lain.

3) Methods (metode kerja), berkaitan dengan tidak adanya prosedur dan metode kerja yang benar, tidak jelas, tidak diketahui, tidak terstandarisasi, tidak cocok, dan lain-lain.

4) Materials (bahan baku dan bahan penolong), berkaitan dengan tidak adanya spesifikasi kualitas dari bahan baku dan bahan penolong yang ditetapkan, tidak adanya penanganan efektif terhadap bahan baku dan bahan penolong, dan lain-lain.

5) Media, berkaitan dengan tempat dan waktu kerja yang tidak memperhatikan aspek-aspek keberhasilan, kesehatan dan keselamatan kerja, dan lingkungan kerja yang tidak kondusif, kekurangan dalam lampu penerangan, ventilasi yang buruk, kebisingan yang berlebihan, dan lain-lain.

6) Motivation (motivasi), berkaitan dengan tidak adanya semangat kerja yang benar dan profesional, yang dalam hal ini disebabkan oleh sistem balas jasa dan penghargaan yang tidak adil kepada tenaga kerja.

7) Money (keuangan), berkaitan dengan tidak adanya dukungan finansial yang mantap guna memperlancar proyek peningkatan kualitas Six Sigma yang direncanakan.

\section{Memperbaiki (Improve)}

Pada langkah ini diterapkan suatu rencana tindakan untuk melaksanakan peningkatan kualitas Six Sigma. Rencana tersebut mendeskripsikan tentang alokasi sumber daya serta prioritas atau alternatif yang dilakukan. Tim 
peningkatan kualitas Six Sigma harus memutuskan target yang akan dicapai, alasan tindakan tersebut dilakukan, kapan rencana tersebut dilaksanakan, siapa penanggung jawab tim, bagaimana melaksanakan program itu dan berapa biaya yang perlu dialokasikan seta manfaat positif dari dilaksanakannya rencana atau program tersebut. Tim proyek perbaikan Six Sigma harus mengidentifikasi sumber-sumber dan akar yang menjadi penyebab masalah kualitas sekaligus memonitor efektifitas dari program perbaikan yang dilakukan secara terusmenerus. Program-program perbaikan dapat dilakukan dengan menggunakan quality tools seperti cause-effect diagram, 5W-1H, Poka Yoke, FTA ataupun FMEA. Dalam penelitian ini penulis memilih bentuk perbaikan yaitu programprogram 5W-1H dan FMEA.

Efektifitas program perbaikan akan tampak dari menurunnya persentase biaya yang timbul akibat kualitas yang rendah atau biaya kegagalan kualitas atau COPQ (Cost of Poor Quality). Turunnya biaya kegagalan kualitas (COPQ) dan meningkatnya nilai penjualan akan menandai meningkatnya kapabilitas Six Sigma perusahaan. Program perbaikan yang dilakukan harus terus menerus dievaluasi efektivitasnya melalui pencapaian target kinerja dalam program peningkatan kualitas Six Sigma yaitu dengan menurunkan defect rate menuju target kegagalan nol (zero defect) atau mencapai kapabilitas proses pada tingkat yang lebih besar atau sama dengan Six Sigma, serta menkonversikan manfaat dan hasil-hasilnya ke dalam penurunan biaya kegagalan kualitas (COPQ).

\section{Mengendalikan (Control)}

Kegiatan kendali (control) adalah merupakan tahap operasional terakhir dalam upaya peningkatan kualitas berdasarkan metode Six Sigma. Pada tahap ini hasil peningkatan kualitas didokumentasikan dan disebarluaskan, praktik-praktik terbaik yang sukses dalam peningkatan proses distandarisasi dan disebarluaskan. Prosedur baku kemudian didokumentasikan dan dijadikan sebagai pedoman standar, serta kepemilikan dan tanggung jawab pemeliharaan dokumen tersebut diserahkan dari tim kepada pemilik atau penanggung jawab proses. Terdapat dua alasan dalam melakukan standarisasi proses, yaitu: 
a) Apabila tindakan peningkatan kualitas atau solusi masalah itu tidak distandarisasi, terdapat kemungkinan bahwa setelah periode waktu tertentu, manajemen dan karyawan akan menggunakan kembali cara kerja yang lama sehingga memunculkan kembali masalah sama dalam proses tersebut.

b) Apabila tindakan peningkatan kualitas atau solusi masalah itu tidak distandarisasi dan didokumentasikan, maka terdapat kemungkinan setelah periode waktu tertentu apabila terjadi pergantian manajemen dan karyawan, orang baru akan menggunakan cara kerja yang akan memunculkan kembali masalah yang sudah pernah terselesaikan oleh manajemen dan karyawan sebelumnya.

\subsubsection{Perhitungan Dengan Metode DMAIC}

Beberapa perhitungan yang berkaitan dengan metode DMAIC (define, measure, analyze, improve and control) adalah sebagai berikut:

\section{Defect per Opportunities}

Defect per opportunities (DPO) adalah suatu ukuran kegagalan yang menunjukkan banyaknya cacat atau kegagalan per satu kesempatan. DPO dapat dihitung dengan menggunakan rumus sebagai berikut:

$$
\begin{aligned}
& D P O=\frac{\text { Jumlah Defect }}{\text { output } x C T Q} \\
& D P O=\frac{\text { Jumlah defect }}{\text { peluang }}
\end{aligned}
$$

\section{DPMO (defect per million opportunites)}

DPMO merupakan suatu kegagalan yang menunjukkan banyaknya cacat atau kegagalan per sejuta kesempatan. Di dalam program peningkatan kualitas Six Sigma target 3,4 DPMO diinterpretasikan dalam satu unit produksi terdapat ratarata kesempatan untuk gagal dari satu karakteristik CTQ adalah 3,4 kegagalan per satu juta kesempatan. DPMO dapat dihitung dengan rumus sebagai berikut:

$\mathrm{DPMO}=\mathrm{DPO} \times 1.000 .000$

\section{Tingkat Sigma atau Sigma Quality Level (SQL)}

Perhitungan level sigma dapat dilakukan dengan menggunakan program excel dan rumus sebagai berikut: 
$S Q L=\varnothing\left[\frac{10^{6}-D P M O}{10^{6}}\right]+1,5$

Dalam perhitungan SQL menggunakan software Six Sigma kalkulator sebagai berikut (Gambar 2.9), atau dapat juga dilakukan dengan menggunakan Tabel Konversi DPMO ke Nilai Sigma yang terdapat pada Lampiran IX.

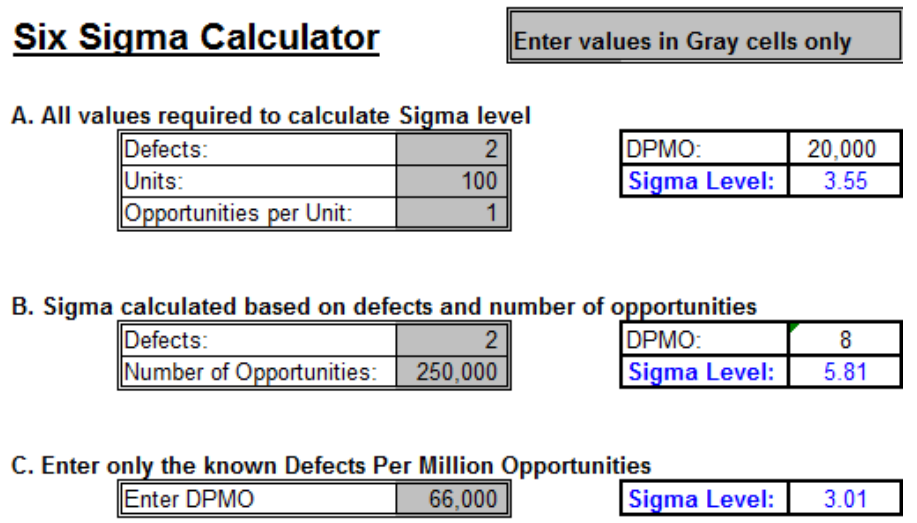

\section{Gambar 2.10 Six Sigma Kalkulator}

\subsubsection{Failure Mode and Effect Analysis (FMEA)}

FMEA pada awalnya dibuat oleh Aerospace Industry pada tahun 1960-an, kemudian FMEA mulai digunakan oleh Ford pada tahun 1980-an. Pada tahun 1993 AIAG (Automotive Industry Action Group) dan American Society for Quality Control (ASQC) menetapkan FMEA sebagai standar quality tool mereka. Saat ini FMEA merupakan salah satu core tools dalam ISO/TS 16949:2002 'Technical Specification for Automotive Industry' (Mc Dermott, 2009: h. 1-4).

FMEA merupakan suatu metode yang digunakan untuk mengetahui atau mengamati apakah suatu tingkat kegagalan dapat dianalisis atau diukur sehingga dapat diantisipasi dan diminimalisasi baik tingkat kegagalannya ataupun efek negatifnya yang berdampak pada faktor-faktor lain ataupun pada output proses. Suatu proses yang spesial/khusus dan yang rentan terhadap kegagalan dan mempengaruhi mutu produk, perlu untuk dievaluasi atau dianalisis dengan menggunakan metode ini. Metode ini juga memberikan tingkatan resiko pada aktivitas-aktivitas ataupun sub-proses atau elemen proses. Metode FMEA yang 
dibuat secara efektif akan dapat mencegah terjadinya resiko kegagalan yang tidak terkendali dan menekan kemungkinan terjadinya kegagalan total suatu proses.

FMEA yang dibuat dengan teliti dan kemudian diterapkan secara maksimal akan memberikan bukan saja efek korektif terhadap proses produksi tetapi juga efek preventif terhadap kegagalan suatu proses. Di banyak organisasi teknis modern FMEA merupakan analisis resiko proses-proses yang bersifat khusus dan juga sebagai tindakan preventif terhadap kegagalan proses. FMEA juga memberikan skala resiko dan prioritas terhadap elemen-elemen proses, sehingga suatu proses dapat terkontrol dengan baik dan pada akhirnya menghasilkan produk (barang atau jasa) yang sesuai dengan spesifikasi yang diinginkan dan memuaskan pengguna dari produk tersebut.

Walaupun pada awalnya FMEA digunakan dalam industri otomotif, tetapi proses pengelasan dalam industri fabrikasi adalah suatu proses khusus (special process) yang mempengaruhi mutu produk secara lansung, sehingga sejak awal proses tersebut perlu direncanakan dan didesain secara optimal sehingga bukan saja proses ini dapat membuahkan hasil dengan baik tetapi juga dapat berjalan tanpa hambatan yang berarti. Hambatan proses yang signifikan terhadap proses pengelasan ini adalah timbulnya defect dalam pengelasan, sehingga metode FMEA ini dapat digunakan untuk menekan probabilitas dari timbulnya defect las yang tidak terkendali.

\subsection{Penelitian Terdahulu}

Penelitian terdahulu adalah berdasarkan hasil laporan kuliah praktek penulis sendiri yang dilakukan di PT Profab Indonesia pada kurun waktu dua bulan yaitu Oktober dan Nopember tahun 2015. Selama penulis melakukan kuliah praktek di PT Profab Indonesia ditemukan bahwa tingkat defect rate di PT Profab Indonesia adalah sebesar $15,5 \%$, dengan rumus sebagai berikut:

$$
\% \text { defect }=\frac{\text { jumlah defect }}{\text { jumlah film RT yang dihasilkan (output) }}
$$


Dari rumus itu maka didapat akumulasi persentase dari jumlah defect dengan keseluruhan film radiografi yang diambil dari seluruh produk pengelasan di bagian produksi selama delapan minggu berturut-turut.

Adapun data film radiografi yang diteliti selama kuliah praktek tersebut dibuatkan tabel sebagaimana terdapat dalam Tabel 2.1 berikut. Dimana terdapat jumlah film yang diradiografi sebanyak 3903 lembar dan dari jumlah itu 605 lembar berisi defect yang harus diperbaiki, dan setelah dikonversi dalam persentase menjadi 15,5\%. Hal ini jauh dari apa yang diharapkan oleh manajemen perusahaan yaitu sebesar $10 \%$ maksimum.

Tabel 2.1 Tabel Proporsi Defect Pengelasan

\begin{tabular}{|c|c|c|c|}
\hline Minggu & Output & Jumlah Defect & \% defect \\
\hline Ke-I & 173 & 33 & 0,1907 \\
\hline Ke-II & 373 & 98 & 0,2627 \\
\hline Ke-III & 396 & 81 & 0,2045 \\
\hline Ke-IV & 405 & 89 & 0,2197 \\
\hline Ke-V & 644 & 73 & 0,1133 \\
\hline Ke-VI & 1075 & 158 & 0,1469 \\
\hline Ke-VII & 423 & 27 & 0,0638 \\
\hline Ke-VIII & 414 & 46 & 0,1111 \\
\hline Total & $\mathbf{3 9 0 3}$ & $\mathbf{6 0 5}$ & $\mathbf{0 , 1 5 5 0}$ \\
\hline
\end{tabular}

Data yang diperoleh dari kuliah praktek juga menunjukkan bahwa jenis defect yang paling banyak menyebabkan kegagalan las adalah slag inclusion, dimana jenis defect ini menduduki peringkat pertama persentase defect pengelasan dan diikuti dengan defect-defect yang lain (lihat Tabel 2.2).

Tabel 2.2 Tabel Persentase Jenis Defect Pengelasan

\begin{tabular}{|c|c|c|c|c|}
\hline No & Jenis Defect & Jumlah Defect & Total Defect & Persentase \\
\hline 1 & Slag Inclusion & 214 & 605 & $35.37 \%$ \\
\hline 2 & Lack of Fusion & 155 & 605 & $25,62 \%$ \\
\hline 3 & Porosity & 132 & 605 & $21,82 \%$ \\
\hline
\end{tabular}




\begin{tabular}{|c|c|c|c|c|}
\hline 4 & Root Concavity & 57 & 605 & $9,42 \%$ \\
\hline 5 & Undercut & 47 & 605 & $7,77 \%$ \\
\hline & Total & 605 & & \\
\hline
\end{tabular}

Setelah mendapatkan jumlah produk atau output dan jumlah defect maka peneliti mencari nilai DPMO yaitu dengan rumus sebagai berikut:

$$
D P M O=\frac{\text { Jumlah defect }}{\text { Jumlah output } X C T Q} \times 10^{6}
$$

Jadi bila jumlah defect yang ditemukan selama bulan Oktober sampai Nopember 2015 dibuatkan DPMO-nya, maka akan menjadi sebagai berikut:

1) $D P M O=\frac{33}{173 \times 5} \times 10^{6}=38150,29$; Nilai Sigma-nya adalah: 3,27

2) $D P M O=\frac{98}{373 \times 5} \times 10^{6}=52546,92$; Nilai Sigma-nya adalah: 3,12

3) $D P M O=\frac{81}{396 \times 5} \times 10^{6}=40909,09$; Nilai Sigma-nya adalah: 3,24

4) $D P M O=\frac{89}{405 \times 5} \times 10^{6}=43950,62$; Nilai Sigma-nya adalah: 3,21

5) $D P M O=\frac{73}{644 \times 5} \times 10^{6}=22670,81$; Nilai Sigma-nya adalah: 3,50

6) $D P M O=\frac{158}{1075 \times 5} \times 10^{6}=29395,35$; Nilai Sigma-nya adalah: 3,39

7) $D P M O=\frac{27}{423 \times 5} \times 10^{6}=12765,96$; Nilai Sigma-nya adalah: 3,73

8) $D P M O=\frac{46}{414 \times 5} \times 10^{6}=22222,22$; Nilai Sigma-nya adalah: 3,51

Nilai Sigma dapat diperoleh baik dengan menggunakan Tabel Konversi DPMO ke Nilai Sigma (lihat Lampiran IX) atau dengan menggunakan Kalkulator Six Sigma. Berdasarkan data yang didapat dari laporan kuliah praktek penulis adalah nilai Sigma hasil konversi defect rate pengelasan menunjukkan rata-rata nilai Sigma sebesar 3,32 sebagaimana tertulis dalam Tabel 2.3 berikut.

Tabel 2.3 Perhitungan Nilai Sigma

\begin{tabular}{|c|c|c|c|c|c|c|}
\hline Minggu & Output & $\begin{array}{c}\text { Jumlah } \\
\text { Defect }\end{array}$ & DPU & Yield & DPMO & $\begin{array}{c}\text { Nilai } \\
\text { Sigma }\end{array}$ \\
\hline Ke-I & 173 & 33 & 0,1907 & $80,92 \%$ & 38150,29 & 3,27 \\
\hline Ke-II & 373 & 98 & 0,2627 & $73,73 \%$ & 52546,92 & 3,12 \\
\hline
\end{tabular}




\begin{tabular}{|c|c|c|c|c|c|c|}
\hline Ke-III & 396 & 81 & 0,2045 & $79,55 \%$ & 40909,09 & 3,24 \\
\hline Ke-IV & 405 & 89 & 0,2197 & $78,02 \%$ & 43950,62 & 3,21 \\
\hline Ke-V & 644 & 73 & 0,1133 & $88,66 \%$ & 22670,81 & 3,50 \\
\hline Ke-VI & 1075 & 158 & 0,1469 & $85,30 \%$ & 29395,35 & 3,39 \\
\hline Ke-VII & 423 & 27 & 0,0638 & $93,62 \%$ & 12765,96 & 3,73 \\
\hline Ke-VIII & 414 & 46 & 0,1111 & $88,89 \%$ & 22222,22 & 3,51 \\
\hline & & & & & & 3,32 \\
\hline
\end{tabular}

\subsection{Kerangka Pikir}

Kerangka berpikir dimulai dengan diketahuinya defect rate yang tinggi di bagian produksi pengelasan di PT Profab Indonesia dengan nilai sebesar 15,5\%, dimana nilai ini diperolah dari data kuliah praktek penulis sendiri. Hal ini kemudian diangkat penulis sebagai masalah yang perlu diatasi. Setelah mengetahui masalah maka penulis kemudian juga melakukan beberapa analisis, seperti analisis dengan menggunakan diagram Pareto, Histogram dan diagram Fishbone untuk melihat penyebab dari tingginya defect rate itu (lihat Gambar 2.11).

Penulis juga menggunakan metode Six Sigma untuk mencari nilai Sigma sekarang (baseline performance) dari persentase defect pengelasan itu, yaitu dengan mencari DPMO dari tiap defect rate setiap minggunya selama delapan minggu. Setelah mengetahui nilai Sigma sekarang maka penulis menggunakan metode FMEA sebagai bagian dari metode kualitas Six Sigma untuk melakukan perbaikan-perbaikan kinerja.

Setelah beberapa waktu menerapkan FMEA maka penulis akan melakukan penelitian lanjutan dengan menggunakan kembali metode-metode analisis Pareto, Histogram dan lain-lain, dan juga dengan menghitung kembali nilai Sigma waktu sekarang. Penulis kemudian akan membandingkan antara nilai Sigma sebelum perbaikan dan nilai Sigma sesudah perbaikan. Apabila nilai Sigma sesudah perbaikan mengalami kenaikan maka itu berarti metode perbaikan FMEA berhasil, namun 
apabila tidak ada perubahan nilai Sigma atau bahkan nilai Sigma menurun maka metode perbaikan FMEA dianggap tidak berhasil dan perlu ditinjau ulang.

\section{KERANGKA PIKIR PENELITIAN}

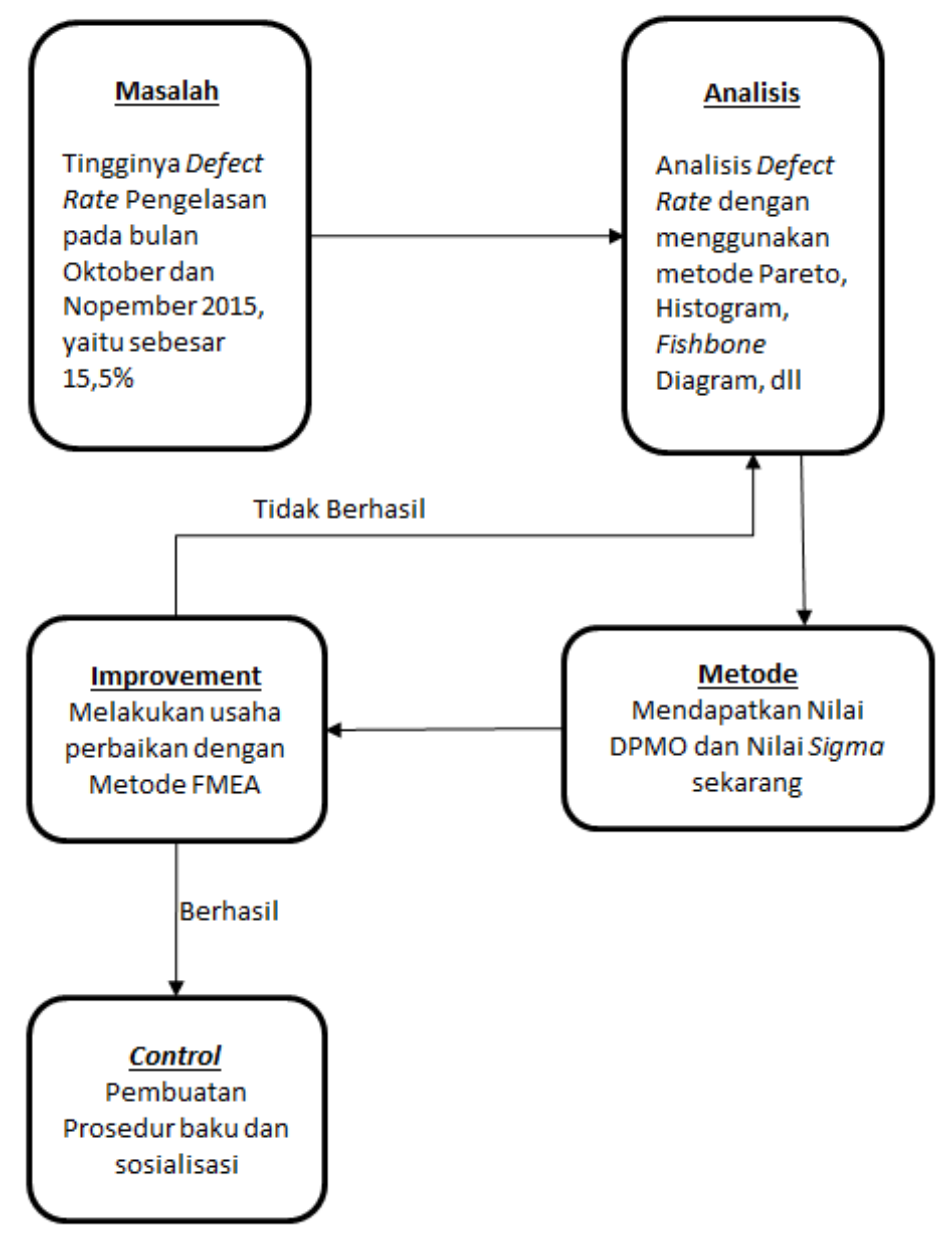

Gambar 2.11 Kerangka Pikir 


\section{BAB III METODOLOGI PENELITIAN}

\subsection{Waktu dan Tempat Penelitian}

Penelitian Tugas Akhir (skripsi) ini dilakukan mulai dari awal bulan April sampai akhir bulan Juni 2016, atau kurang lebih selama 12 minggu (3 bulan), sebagai lanjutan dari penelitian Kuliah Praktek yang dilakukan penulis sendiri pada bulan Oktober dan Nopember 2015, dengan tempat penelitian yang sama yaitu di PT Profab Indonesia, yang beralamat di Jalan Bawal Kav V, Batu Merah, Pulau Batam.

\subsection{Jenis Data}

1. Jenis Data

Jenis data yang digunakan dalam penelitian ini adalah data sekunder yang merupakan data sebelumnya yang sudah ada di PT Profab Indonesia yang menjadi tempat penelitian. Data yang diperoleh berupa data kuantitatif dan data kualitatif. Data kuantitatif yaitu data yang berupa angka-angka mengenai output jumlah pengelasan yang dilakukan uji radiografi dan dan data pengelasan yang mengalami defect. Data kualitatif yaitu data yang berupa informasi mengenai jenis cacat las, penyebab terjadinya cacat las, proses las yang digunakan dan bahan baku yang digunakan.

2. Sumber Data

Sumber data secara keseluruhan diperoleh dari institusi yang menjadi tempat penelitian. Data yang bersifat kuantitatif diperoleh dari dokumen/arsip bagian quality control dan bagian quality assurance. Sedangkan data yang bersifat kualitatif diperoleh dari wawancara dan pengamatan secara langsung di perusahaan.

\subsection{Populasi dan Sampel Penelitian}

Penelitian yang dilakukan tidak mengambil sampel, tetapi menggunakan keseluruhan data populasi dari semua produk pengelasan yang dilakukan inspeksi radiografi selama bulan Juni 2016 sebagaimana yang telah dilakukan sebelumnya 
pada bulan Oktober dan Nopember 2015, yaitu hasil radiografi produk pengelasan yang dicatat oleh departemen quality control (QC).

\subsection{Variabel Penelitian dan Definisi Operasional}

Variabel penelitian merupakan suatu atribut atau sifat yang mempunyai variasi tertentu yang ditetapkan oleh peneliti untuk dipelajari dan ditarik kesimpulannya. Penelitian ini menggunakan dua macam variabel yaitu variabel bebas dan variabel terikat. Variabel bebas adalah variabel yang keberadaannya tidak dipengaruhi atau ditentukan oleh variabel-variabel lainnya dalam hal ini adalah variabel jumlah defect atau defect rate pengelasan, sedangkan variabel terikat yaitu variabel yang ditentukan dan dipengaruhi oleh variabel bebas yaitu dalam hal ini adalah berupa besaran KPI (Key Performance Indicator) perusahaan yang ingin dicapai oleh manajemen, dimana pencapaiannya ditentukan dan dipengaruhi oleh besarnya nilai variabel bebas yaitu defect rate.

Untuk KPI ini manajemen menetapkan target bahwa maksimum defect rate dalam pengelasan adalah sebesar $10 \%$.Variabel jumlah defect atau defect rate ini akan mempengaruhi KPI perusahaan yang telah ditetapkan sebelumnya oleh manajemen. Jadi dengan mengusahakan perbaikan pada variabel bebas maka akan memberikan hasil yang baik bagi pencapaian variabel terikatnya yaitu KPI yang diharapkan oleh perusahaan.

Definisi operasional dalam penelitian ini berfokus pada pengendalian kualitas dan untuk mencapai tingkat kualitas produk yang distandarkan oleh perusahaan sesuai dengan pedoman kualitas yang ditetapkan oleh PT Profab Indonesia. Hal ini untuk mencapai, mempertahankan dan meningkatkan kualitas kinerja perusahaan sehingga menghasilkan suatu produk atau jasa sesuai dengan sasaran mutu yang telah ditetapkan perusahaan di awal kegiatan.

Pengendalian kualitas yang merupakan bagian terpenting dalam menanggulangi masalah kualitas secara cermat dilakukan oleh tim Six Sigma perusahaan dan pengendalian tersebut meliputi tiga tahapan, yaitu:

1. Pengendalian terhadap bahan baku pengelasan.

2. Pengendalian terhadap proses pengelasan.

3. Pengendalian terhadap hasil pengelasan sebelum dilakukan pengujian. 


\subsection{Metode Pengumpulan Data}

Metode pengumpulan data yang digunakan dalam penelitian ini adalah dengan melakukan pengamatan langsung di perusahaan yang menjadi obyek penelitian. Teknik pengumpulan data yang dilakukan adalah sebagai berikut:

\section{Wawancara}

Merupakan suatu cara untuk mendapatkan data atau informasi dengan tanya jawab secara langsung pada orang yang mengetahui tentang obyek yang diteliti. Dalam hal ini adalah dengan pihak manajemen dan karyawan PT Profab Indonesia yang mencatat data mengenai jenis-jenis produk cacat dan penyebabnya, proses produksi serta bahan baku yang digunakan.

2. Observasi

Yaitu pengamatan atau peninjauan secara langsung di tempat penelitian PT Profab Indonesia dengan mengamati sistem atau cara kerja perusahaan, mengamati proses produksi dari awal sampai akhir, dan kegiatan inspeksi produk akhir.

3. Dokumentasi

Yaitu dengan mempelajari dokumen-dokumen perusahaan yang berupa laporan kegiatan produksi, laporan jumlah pengelasan yang diperiksa dengan metode radiografi dan jumlah pengelasan yang terdapat cacat, rencana kerja, serta dokumen lainnya.

\subsection{Metode Pengolahan Data}

1. Implementasi analisis weld defect (cacat las) dengan metode Six Sigma. Metode yang digunakan mengacu pada prinsip-prinsip yang terdapat dalam metode Six Sigma. Metode ini digunakan untuk mengantisipasi terjadinya kesalahan atau defect (cacat) dengan menggunakan langkah-langkah terukur dan terstruktur. Dengan berdasarkan pada data yang ada, maka continuous improvement dapat dilakukan berdasarkan metodologi Six Sigma yang meliputi tahapan proses DMAIC.

a. Menetapkan (Define) 
Pada tahapan ini ditentukan proporsi defect yang menjadi penyebab paling signifikan terhadap adanya kerusakan yang merupakan sumber kegagalan las atau produksi. Cara yang ditempuh adalah:

1) Mendefinisikan masalah standar kualitas dalam menghasilkan produk pengelasan yang telah ditentukan perusahaan.

2) Mendefinisikan rencana tindakan yang harus dilakukan berdasarkan hasil observasi dan analisis penelitian.

3) Menetapkan sasaran dan tujuan peningkatan kualitas Six Sigma berdasarkan hasil observasi.

\section{b. Mengukur (measure)}

Tahap pengukuran dilakukan melalui beberapa tahap dengan pengambilan sampel pada perusahaan selama masa kuliah praktek pada bulan Oktober dan Nopember 2015 sebagai berikut:

\section{Analisis Diagram Kontrol}

Diagram kontrol digunakan untuk mengukur jumlah maksimum persentase defect yang didapat berdasarkan proporsi jumlah suatu kejadian seperti diterima atau ditolaknya hasil las sebagai akibat dari proses pengelasan. Dalam perhitungan dan analisis diagram kontrol ini perhitungan menggunakan total defect per total output welding yang diinspeksi melalui metode testing radiografi tiap minggu selama bulan Oktober dan Nopember 2015. Diagram ini dapat disusun dengan langkah sebagai berikut:

a) Pengambilan populasi dan sampel

Penulis tidak mengambil sampel, tetapi seluruh populasi hasil uji radiografi perusahaan dianalisis menggunakan control chart.

Pemeriksaan karakteristik dengan menghitung nilai mean dengan rumus sebagai berikut:

$$
\text { Rata }- \text { rata proporsi }=\frac{\text { Total Defoct }}{\text { Total Sampel }}
$$

\section{Keterangan:}

Total defect dengan satuan film

Total sampel (pengelasan yang diuji radiografi) 
Rata-rata proporsi kecacatan (defect)

b) Menentukan batas kendali terhadap pengawasan yang dilakukan dengan menetapkan nilai UCL (upper control limit) atau batas spesifikasi atas dan LCL (lower control limit) atau batas spesifikasi bawah.

$$
\begin{aligned}
& U C L=C L+3 \sqrt{\frac{\text { Rata-rata proposi defect }(1-\text { rata - rata proporsi defect) }}{\text { Total Sampel }}} \\
& L C L=C L-3 \sqrt{\frac{\text { Rata-rata proposi def eat (1-rata-rataproporsi def } \theta 0 t)}{\text { Total Sampel }}}
\end{aligned}
$$

Keterangan:

UCL : Upper Control Limit

LCL : Lower Control Limit

CL : Center Line

c) Analisis tingkat Sigma dan DPMO (defect per million opportunities) perusahaan dilakukan sebagaimana Tabel 3.1 di bawah ini.

Tabel 3.1 Analisis Tingkat Sigma dan DPMO

\begin{tabular}{|c|l|c|}
\hline Langkah & \multicolumn{1}{|c|}{ Tindakan } & Persamaan \\
\hline 1 & Proses apa yang akan diketahui & - \\
\hline 2 & $\begin{array}{l}\text { Berapa banyak film pengelasan } \\
\text { yang diradiografi }\end{array}$ & - \\
\hline 3 & $\begin{array}{l}\text { Berapa banyak film pengelasan } \\
\text { yang terdeteksi cacat (defect) }\end{array}$ & - \\
\hline 4 & $\begin{array}{l}\text { Menghitung tingkat kecacatan } \\
\text { berdasarkan langkah 3 }\end{array}$ & Langkah 3/Langkah 2 \\
\hline 5 & $\begin{array}{l}\text { Tentukan CTQ penyebab } \\
\text { produk cacat }\end{array}$ & Banyaknya karakteristik \\
\hline 6 & $\begin{array}{l}\text { Menghitung peluang tingkat } \\
\text { cacat kareakteristik CTQ }\end{array}$ & Langkah 4/Langkah 5 \\
\hline 7 & $\begin{array}{l}\text { Menghitung kemungkinan } \\
\text { cacat per DPMO }\end{array}$ & Langkah 6 x 1.000.000 \\
\hline
\end{tabular}




\begin{tabular}{|l|l|c|}
\hline 8 & $\begin{array}{l}\text { Konversi DPMO ke dalam } \\
\text { nilai Sigma }\end{array}$ & - \\
\hline
\end{tabular}

c. Menganalisis (Analyze)

Mengidentifikasi penyebab masalah kualitas dengan menggunakan

1. Diagram Pareto

Setelah melakukan pengukuran (measure) dengan diagam control chart, maka akan diketahui apakah ada produk yang berada di luar batas kontrol atau tidak. Jika ternyata diketahui ada produk defect yang berada di luar batas kontrol, maka pengelasan tersebut akan dianalisis dengan menggunakan diagram pareto untuk diurutkan berdasarkan tingkat proporsi kerusakan terbesar sampai dengan terkecil. Diagram pareto ini akan membantu untuk memfokuskan pada masalah defect pengelasan yang lebih sering terjadi, yang mengisyaratkan masalah-masalah mana yang bila ditangani akan memberi manfaat yang besar.

\section{Diagram Sebab Akibat (Cause and Effect Diagram)}

Diagram sebab akibat digunakan sebagai pedoman teknis dari fungsifungsi operasional proses produksi untuk memaksimalkan nilai-nilai kesuksesan tingkat kualitas produk sebuah perusahaan pada waktu bersamaan dengan memperkecil resiko-resiko kegagalan.

\section{d. Memperbaiki (Improve)}

Merupakan tahap peningkatan kualitas Six Sigma dengan melakukan pengukuran dengan melihat dari peluang perbaikan, trend kecacatan, proses kapabilitas, rekomendasi ulasan perbaikan, menganalisis tindakan perbaikan yang akan dilakukan. Penulis juga menggunakan metode FMEA dimana perbaikan dilakukan hampir disemua elemen yang dianggap mempengaruhi mutu pengelasan.

e. Melakukan kegiatan kendali (Control)

Merupakan tahap peningkatan kualitas dengan memastikan level baru kinerja dalam kondisi standar dan terjaga nilai-nilai peningkatannya yang kemudian didokumentasikan dan disebarluaskan yang berguna sebagai langkah perbaikan untuk kinerja proses berikutnya. 
2. Analisis Faktor-Faktor yang menyebabkan terjadinya cacat produk.

Kelemahan dan penyimpangan yang terjadi pada proses ditelusuri sebabsebabnya dengan menggunakan analisis diagram sebab akibat. Faktor-faktor yang mempengaruhi kelemahan proses yang menimbulkan terjadinya cacat pengelasan diteliti dengan cara melakukan analisis pada mesin, juru las dan bahan baku las.

\subsection{Kerangka Pemecahan Masalah}

Kerangka pemecahan masalah dibuat dalam bentuk diagram alur penelitian sebagai lihat Gambar 3.1 di bawah. Adapun untuk memperjelas diagram tersebut maka diberikan keterangan sebagai berikut:

1. Memulai Penelitian

Langkah awal penelitian dimulai dari penentuan topik penelitian dan mencari literatur dan bahan-bahan pustaka yang berhubungan dengan topik penelitian.

2. Penentuan Topik Penelitian

Pada tahap ini adalah langkah menggali masalah yang didapat dari hasil kuliah praktek yang akan dicarikan solusinya dalam bentuk tugas akhir (skripsi) ini yaitu bagaimana mengurangi defect rate dari hasil pengelasan di PT Profab Indonesia.

\section{Mencari Literatur}

Langkah selanjutnya adalah mencari literatur-literatur dan bahan-bahan pustaka yang berhubungan dengan metode-metode yang akan dipakai untuk mengatasi masalah yaitu dengan menurunkan defect rate yang terjadi dalam pengelasan.

4. Mencari Dasar Teori

Dengan mempelajari dasar-dasar teori yang mendukung penelitian maka akan didapat cara untuk menentukan tujuan penelitian berupa menurunkan defect rate pengelasan. Dasar-dasar teori yang digunakan dalam penelitian ini adalah dasar teori Six Sigma dimana hal ini akan meliputi keseluruhan metode dan teori bagaimana mencapai zero defect dalam suatu produksi.

5. Menentukan Tujuan Penelitian. 
Tujuan penelitian adalah mengatasi masalah dengan mencari metode-metode apa saja yang cocok untuk digunakan dalam mengurangi defect rate. Setelah itu melihat apakah metode-metode yang digunakan tersebut berhasil memberikan solusi terhadap masalah yang ada.

6. Menentukan Lingkup Penelitian.

Ruang lingkup perlu ditetapkan supaya penelitian ini menjadi lebih terfokus. Adapun ruang lingkup penelitian adalah hasil radiografi pengelasan di PT. Profab Indonesia.

7. Tahap Mengidentifikasi Masalah (Define)

Tahap ini langkah untuk mengidentifikasi secara jelas masalah yang dihadapi oleh perusahaan. Untuk mendefinisikan CTQ dari hasil pengelasan, Diagram SIPOC, dan sebagainya.

\section{Tahap Pengukuran (Measure)}

Tahap ini terlebih dahulu harus dipahami proses internal perusahaan yang sangat potensial dalam mempengaruhi cacat pengelasan dengan cara menentukan karakteristik kualitas (CTQ). Kemudian mengukur besaran penyimpangan yang terjadi dibandingkan dengan standar mutu yang telah ditetapkan dengan cara menghitung DPMO dan nilai Sigma.

9. Tahap Analisis (Analyze)

Pada tahap ini dilakukan upaya memahami mengapa terjadi penyimpangan dan mencari alasan-alasan yang mengakibatkan terjadinya cacat las. Analisis dilakukan dari data yang telah dikumpulkan dengan menggunakan alat bantu kualitas yaitu diagram pareto dan diagram sebab akibat untuk mendapatkan penyebab-penyebab dari permasalahan.

\section{Tahap Perbaikan (Improve)}

Setelah akar penyebab masalah kualitas teridentifikasi maka perlu dilakukan penetapan rencana tindakan untuk melaksanakan peningkatan kualitas. Dalam perbaikan kualitas di sini digunakan metode-metode seperti $5 \mathrm{~W}-1 \mathrm{H}$ dan FMEA (Failure Mode and Effect Analysis).

Pada tahap improvement ini digunakan metode FMEA dimana FMEA adalah sebuah metode yang digunakan untuk mengetahui pola kegagalan dan cara menganalisis efeknya sehingga kita dapat mengetahui akar penyebab (root 
cause) dari masalah dan mencari solusi pemecahan masalah itu dengan tindakan korektif (corrective action) yang tepat sasaran sehingga masalah atau problem atau kegagalan yang sama tidak akan berulang di masa yang akan datang. Selain sebagai cara pemecahan masalah FMEA juga dapat digunakan sebagai cara preventif untuk menghindari masalah sebelum masalah tersebut terjadi. Jadi FMEA dapat juga dijadikan sebagai bentuk dari tindakan preventif (preventive action) dan metode penilaian risiko (risk assessment) dari suatu proses produksi atau proses kerja. Sesuai dengan itu maka standar mutu ISO 9001 (2015) mulai mensyaratkan organisasi atau perusahaan untuk melaksanakan penilaian risiko (risk assessment) dalam setiap prosesnya sebagai bentuk persyaratan QMS (Quality Management System) perusahaan dan FMEA adalah salah satu cara yang digunakan sebagai metode penilaian risiko.

Sebenarnya ada sedikit kemiripan antara FMEA dan diagram sebab akibat yang juga telah dibahas sebelumnya dalam mencari akar permasalahan, hanya saja dalam FMEA telah dapat diketahui nilai prioritas dari suatu masalah sehingga kita dapat mengambil langkah yang lebih tepat lagi dalam melakukan tindakan korektif bagi masalah yang telah terjadi dan tindakan preventif bagi masalah yang belum pernah terjadi tetapi mungkin akan terjadi. FMEA memberikan tiga kriteria bagi setiap masalah yang terjadi yaitu kriteria severity yaitu seberapa parah dampak suatu masalah yang terjadi atau yang akan terjadi bagi proses produksi dan yang kedua adalah kriteria occurrence yaitu seberapa sering kemungkinannya hal itu akan terjadi atau terjadi lagi dan yang terakhir adalah kriteria detection yaitu seberapa mudah kita dapat mendeteksi suatu masalah itu akan terjadi atau terjadi lagi. Ketiga kriteria inilah yang kemudian membentuk Risk Priority Number (RPN), dimana semakin tinggi RPN-nya maka semakin besar prioritas yang diberikan untuk menanggulangi masalah tersebut bila sudah terjadi atau mencegah masalah tersebut dari terjadi atau terjadi lagi.

FMEA memberikan kita peluang untuk menganalisis suatu tindakan korektif atau mitigasi efektif atau tidak yaitu dengan cara memberikan nilai RPN setelah tindakan korektif atau mitigasi dilakukan. Indikasinya adalah apabila 
nilai RPN menurun setelah suatu proses tindakan korektif atau mitigasi maka tindakan tersebut dianggap efektif. Tindakan mitigasi disini adalah tindakan penurunan risiko dari suatu masalah yang diidentifikasi sebagai suatu risiko, sehingga masalah tersebut benar-benar dapat dicegah sebelum terjadi.

\section{Tahap Pengendalian / Pengawasan (Control)}

Pada tahap akhir ini adalah langkah untuk mempertahankan perbaikanperbaikan yang telah dilakukan, mendokumentasikan dan menyebarluaskan informasi-informasi sehubungan dengan perbaikan-perbaikan tersebut sehingga terjadi suatu sistem pengendalian menyeluruh untuk memperoleh hasil yang lebih baik.

12. Kesimpulan Penelitian

Kesimpulan penelitian akan menjadi akhir dari keseluruhan laporan tugas akhir (skripsi) ini. Kesimpulan ini dapat berarti positif karena data yang diperoleh valid dan hasil penelitian dapat diterima, atau dapat juga bernilai negatif dimana data yang diperoleh tidak valid dan hasil penelitian tidak dapat diterima serta sasaran yang diinginkan oleh perusahaan tidak dapat tercapai. 


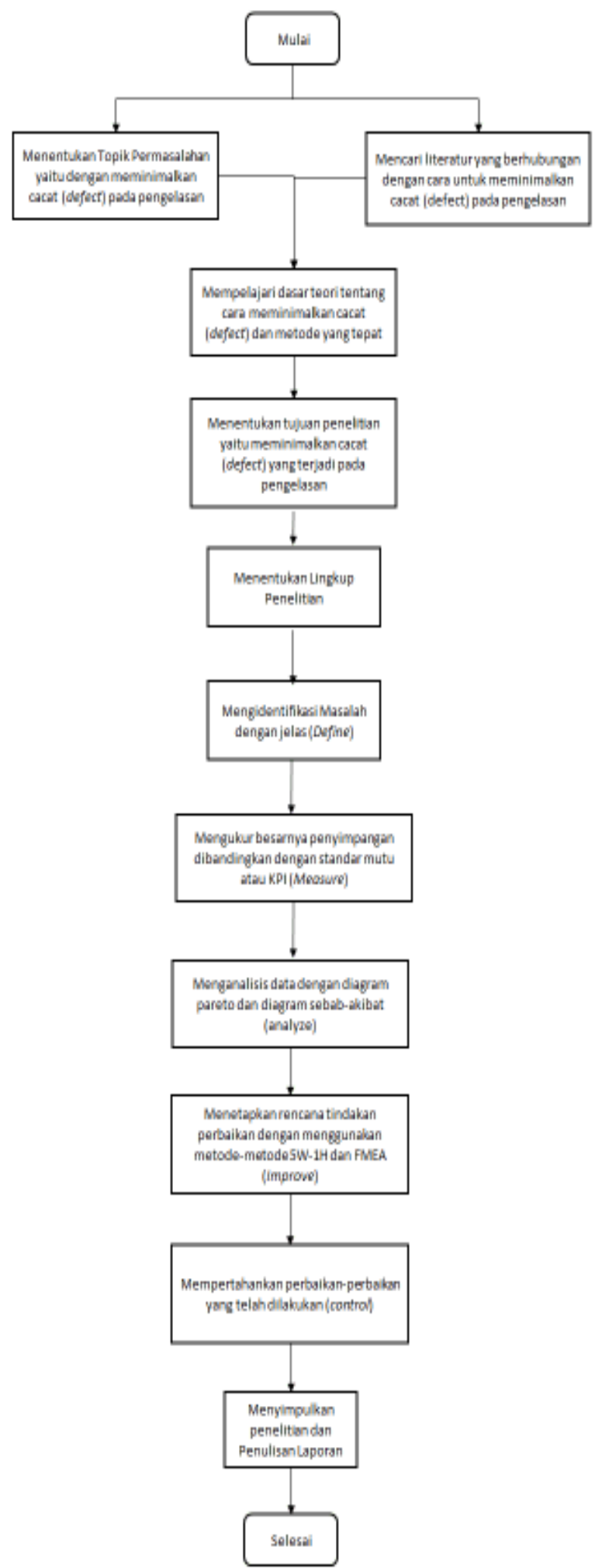

Gambar 3.1 Diagram Alur Penelitian 


\subsection{Jadwal Penelitian}

Jadwal penelitian yang akan dilakukan oleh penulis di PT Profab Indonesia dilaksanakan dalam tiga bulan atau dua belas minggu. Jadwal penelitian ini secara rinci digambarkan dalam diagram Gantt Chart di bawah (lihat gambar 3.2).

Berikut ini adalah rincian jadwal penelitian dan penyusunan skripsi yang dilakukan selama 12 minggu dengan rincian aktivitas sebagai berikut:

- Melakukan pertemuan dengan pembimbing

- Melakukan pertemuan dengan manajemen perusahaan

- Melakukan observasi dan wawancara

- Mengumpulkan data

- Melakukan pertemuan dengan para supervisor dan foreman bidang pengelasan.

- Melakukan pertemuan dengan bidang Quality Control (QC) 
III-13

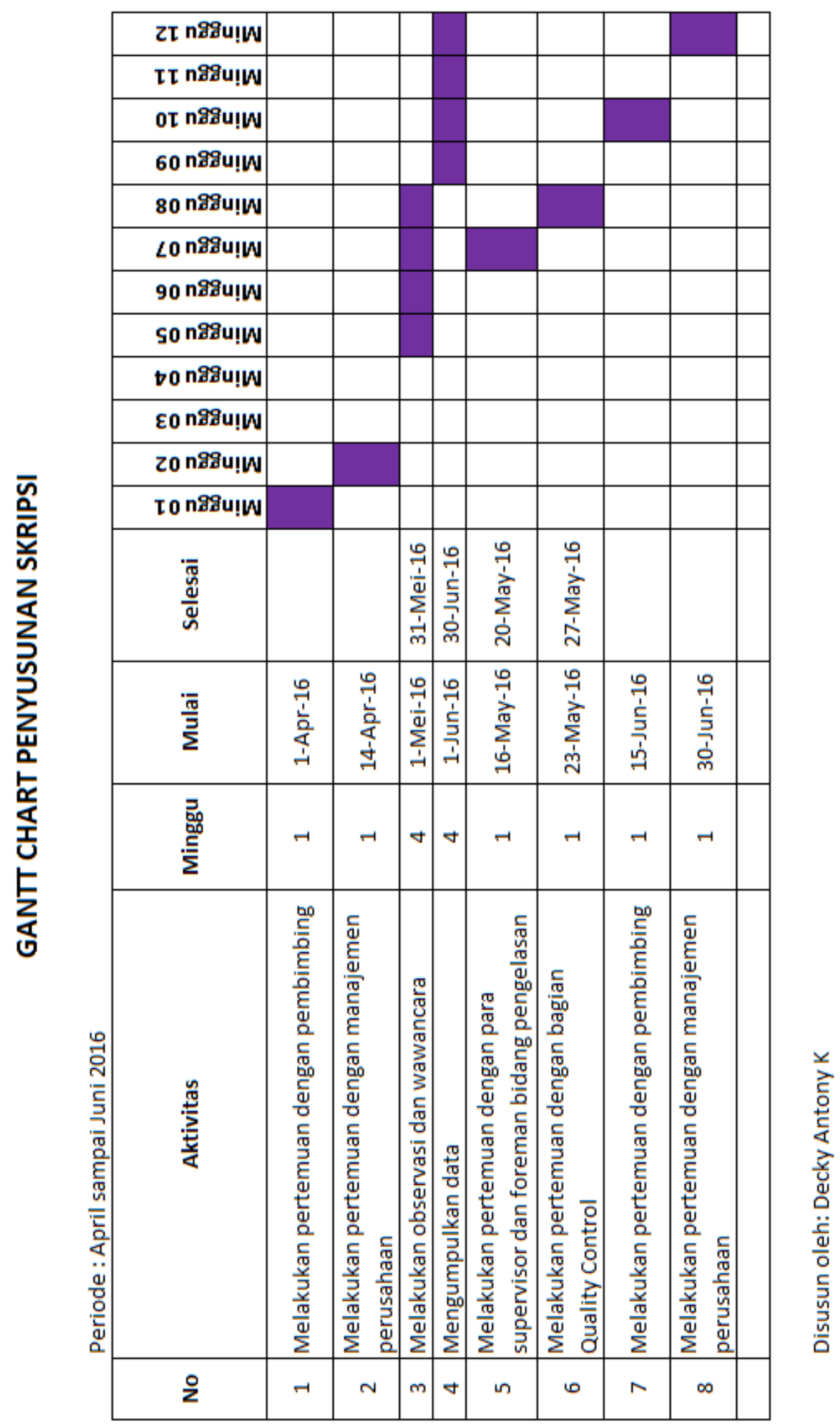

Gambar 3.2 Gantt Chart Penelitian dan Penyusunan Skripsi 


\section{BAB IV}

\section{PENGOLAHAN DATA DAN PEMBAHASAN}

Dalam bab ini dibahas bagaimana penerapan metode Six Sigma dan FMEA pada produksi pengelasan (welding) di PT Profab Indonesia sebagai metode dan tools untuk menganalisis defect atau cacat las pada proses produksi pengelasan.

Six Sigma sebagai salah satu alternatif dalam prinsip-prinsip pengendalian kualitas, dengan metode Six Sigma memungkinkan perusahaan melakukan peningkatan-peningkatan dengan terobosan yang kuat. Six Sigma merupakan alat penting bagi manajemen produksi untuk menjaga, memperbaiki, mempertahankan kualitas produk dan terutama untuk mencapai peningkatan kualitas menuju zero defect. Dalam penelitian ini penerapan analisis defect yang digunakan adalah dengan metode Six Sigma yang melalui lima tahap analisis yaitu DMAIC atau define, measure, analyze, improve dan control.

Analisis hasil penelitian menggunakan metode Six Sigma yang terdiri dari lima tahap yaitu define, measure, analyze, improve, dan control pada PT. Profab Indonesia fokus pada bagian produksi pengelasan (welding) dengan metode inspeksi menggunakan radiography test (gamma ray) sebagai berikut:

\subsection{Mendefinisikan (Define)}

Dalam tahap define ini dapat diketahui bahwa terdapat rata-rata jumlah defect weld yang dihitung dari jumlah film radiografi yang reject pada bulan OktoberNopember 2015 adalah sebesar $15.50 \%$, data ini diambil dari rumus jumlah defect per jumlah out film radiografi.

$$
\% \text { defect }=\frac{\text { jumlah defect }}{\text { jumlah RT film yang dihasilkan (output) }}
$$

Hal ini sangat berpengaruh terhadap KPI sistem manajemen mutu (QMS) PT Profab Indonesia yang menetapkan maksimum weld defect rate sebesar $10 \%$. Dampak dan imbas defect pengelasan ini dapat mempengaruhi image atau reputasi perusahaan di mata pelanggan, dimana tingkat kepuasan pelanggan akan ditentukan dari pencapaian kualitas produksi yang dihasilkan perusahaan. Selain mempengaruhi kepuasan pelanggan, defect ini juga menyebabkan biaya menjadi 
lebih besar dikarenakan perusahaan harus memperbaiki produk pengelasan yang cacat tersebut dan membuang defect dalam pengelasannya dan melakukan pengelasan dan inspeksi ulang sebelum dapat diterima oleh pihak QC (Quality Control) dan pelanggan, biaya-biaya yang dikeluarkan tersebut disebut juga sebagai cost of poor quality. Untuk kemajuan perusahaan ke depannya, PT Profab Indonesia harus meningkatkan kualitas produk maupun proses produksi agar jumlah defect pengelasan dapat diminimalisasikan. Aktivitas utama pada tahap define ini adalah menetapkan CTQ (Critical to Quality), yaitu sebuah fokus terhadap permasalahanpermasalahan yang terjadi dalam rangka memenuhi keinginan pelanggan.

Pada tahap ini yang pertama kali dilakukan adalah menetapkan proyek yang akan dijalankan berdasarkan skala prioritas yang telah ditentukan, dan setelah itu kemudian menentukan CTQ. Hal ini dilakukan adalah untuk mengetahui keinginan dari konsumen yang sesuai dengan tujuan dari metode Six Sigma yaitu memberikan kepuasan kepada konsumen. Hal selanjutnya adalah membentuk tim, membuat jadwal proyek, membuat peta proses dan yang terakhir adalah mengidentifikasi proses yang mempengaruhi CTQ atau biasa disebut juga sebagai CTP (Critical to Process).

Dalam penelitian ini digunakan data output hasil radiografi dari pengelasan di PT Profab Indonesia di bulan Oktober-Nopember 2015. Dari data tersebut dapat diketahui jumlah film radiografi yang berisi defect pengelasan dan jenis-jenis cacat yang terjadi dalam pengelasan tersebut. Dengan mengetahui jenis-jenis defect pengelasan yang ada pada pengelasan yang dihasilkan oleh departemen welding di PT Profab Indonesia, maka pihak perusahaan dapat memfokuskan pada mengidentifikasi jenis-jenis defect pengelasan yang paling banyak terjadi atau yang memiliki kontribusi terbesar dalam permasalahan. Dengan meminimalkan jumlah defect pengelasan maka tingkat kualitas produk yang diinginkan pelanggan akan dapat dengan mudah dicapai, serta sasaran QMS (quality management system) perusahaan sehubungan dengan cost of poor quality dapat diminimalkan.

Berikut ini adalah grafik-grafik analisis weld defect pada departemen pengelasan di PT Profab Indonesia pada bulan Juni 2016 dengan menggunakan Time Series Plot dan Chart dari jenis-jenis defect. 


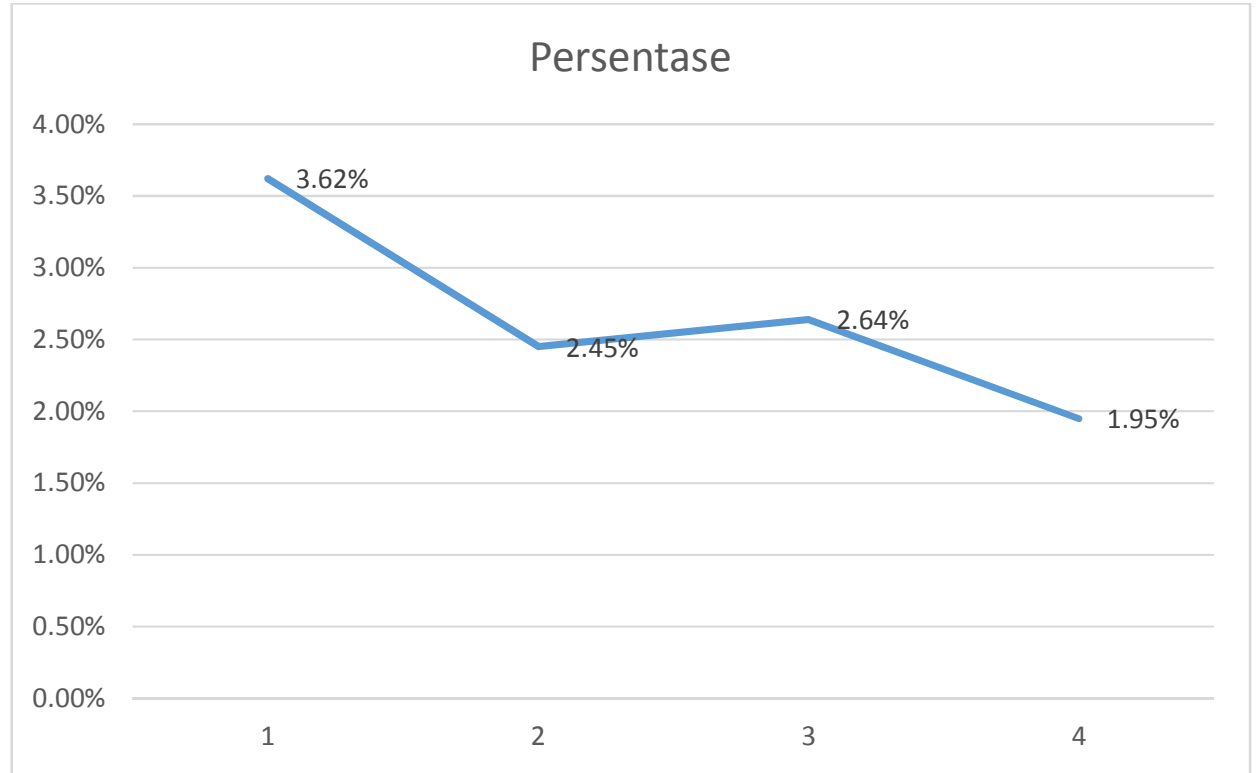

Gambar 4.1. Time Series Plot dari Prosentase Defect bulan Juni 2016

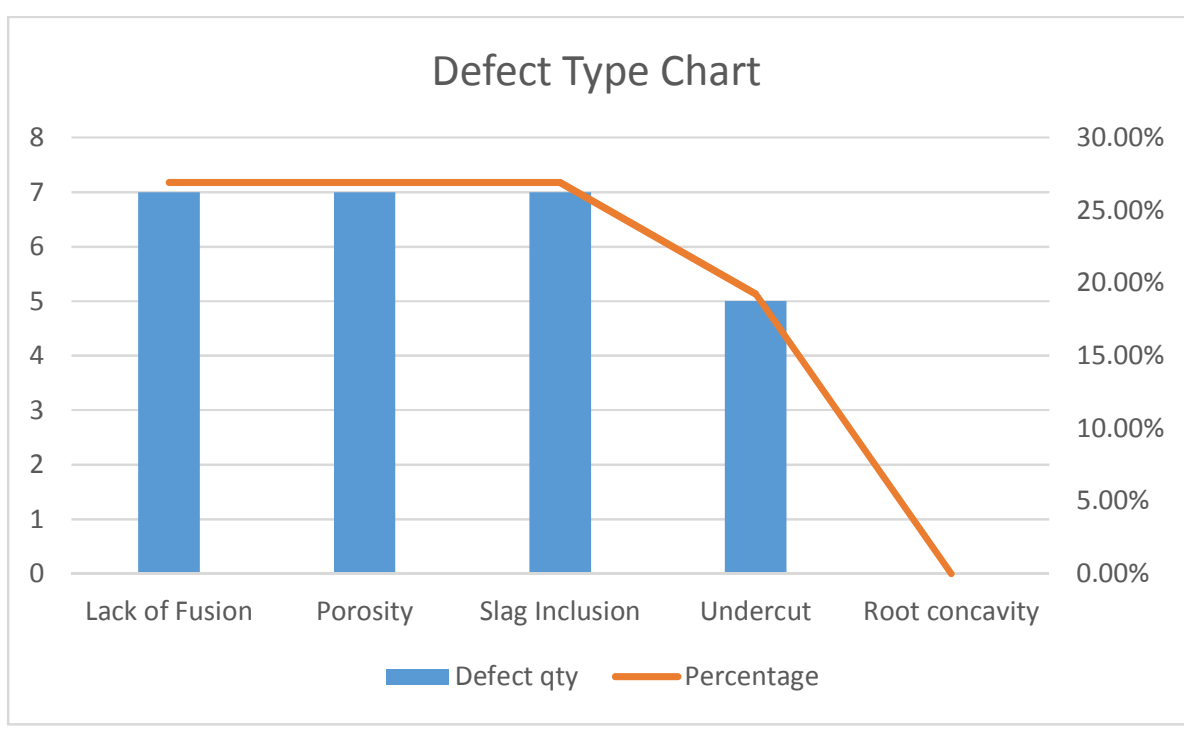

Gambar 4.2. Diagram Jenis-jenis Defect

a. Proses mapping dengan konsep SIPOC

Sebelum melakukan perbaikan pada suatu proses maka terlebih dahulu kita harus mengerti bagaimana proses itu sebenarnya berjalan. Process mapping atau peta proses memberikan gambaran bagaimana langkah-langkah proses pengelasan dilakukan dan ketergantungannya pada proses-proses sebelumnya dan pengaruhnya pada proses-proses setelahnya. Pada diagram SIPOC 
(Supplier, Input, Process, Output, Customer) ini dijelaskan secara lengkap alur proses mulai dari pemasok (supplier) sampai pada pelanggan (customer). Dibawah ini adalah diagram SIPOC untuk kegiatan proses pengelasan ini:

\begin{tabular}{|c|c|c|c|c|}
\hline SUPPLIER & INPUT & PROCESS & OUTPUT & CUSTOMER \\
\hline Gudang & Kawat Las & $\begin{array}{c}\text { Proses } \\
\text { Pengelasan }\end{array}$ & $\begin{array}{c}\text { Hasil } \\
\text { Pengelasan }\end{array}$ & Assembly \\
\cline { 2 - 2 } & $\begin{array}{c}\text { Bahan yang } \\
\text { akan dilas }\end{array}$ & & Inspeksi NDT & QC \\
\hline
\end{tabular}

\section{Gambar 4.3. Diagram SIPOC Proses Pengelasan}

Diagram SIPOC di atas yang merupakan rangkaian aliran sistem produksi pengelasan di PT Profab Indonesia, untuk lebih jelasnya dapat dilihat pada keterangan di bawah ini:

\section{Supplier}

Supplier atau pemasok ini merupakan perusahaan/organisasi yang menjual atau menyuplai bahan untuk berbagai kebutuhan PT Profab Indonesia baik itu bahan baku baja berupa pelat, pipa, flensa dan bahan-bahan baku yang lain seperti baut, mur, gasket dan lain-lain. Bahan pengisi las atau kawat las juga dipasok oleh supplier. Supplier-supplier utama dari bahan baja dan bahan pengisi las banyak berasal dari luar negeri seperti Singapura, Korea Selatan dan Jepang.

\section{Input}

Input merupakan bahan baku dan bahan-bahan lain yang dipasok oleh supplier yang digunakan untuk proses pengelasan. Bahan baku ini terdiri dari berbagai jenis material dan perlengkapannya sehingga dapat memenuhi kebutuhan PT Profab Indonesia untuk membuat produk yang sesuai dengan keinginan pelanggan. Selain bahan baku, input dari supplier juga dapat berupa jasa, seperti jasa inspeksi NDT (non-destructuve testing), jasa pengerolan dan lain-lain.

Peralatan yang digunakan dalam proses pengelasan juga mempengaruhi hasil proses. Kesalahan dalam penggunaan peralatan akan berdampak 
besar pada kualitas produk las yang dihasilkan. Masing-masing proses las yang digunakan memiliki karakteristik tersendiri sehingga peralatan yang digunakan juga harus spesifik untuk masing-masing proses las.

\section{Process}

Proses merupakan operasi pengerjaan yang dilakukan oleh PT Profab Indonesia dalam menghasilkan produknya dan operasi yang dimaksud adalah operasi pengelasan atau proses pengelasan. Input material akan melalui proses pengelasan dan akan berubah menjadi output sesuai dengan desain dan gambar dari bagian engineering. Apabila proses berjalan dengan baik dan terkendali maka output pengelasan akan berhasil dengan baik, namun apabila proses atau input tidak sesuai dengan persyaratan proses maka proses akan menjadi tidak terkendali sehingga output pengelasan akan menjadi tidak baik atau tidak sesuai dengan persyaratan standar atau spesifikasi pelanggan.

\section{Output}

Setelah melawati proses pengerjaan atau proses pengelasan tersebut, maka akan dihasilkan produk pengelasan sesuai dengan persyaratan standar dan pelanggan. Produk yang berupa hasil pengelasan ini kemudian diperiksa secara visual ataupun dengan NDT (non-destructive testing) atau uji tidak merusak. Dari hasil inspeksi visual dan NDT ini kemudian didapat kesimpulan apakah hasil pengelasan sebagai output memenuhi standar kualitas yang diinginkan atau tidak. Apabila hasil pengelasan memuaskan maka produk akan diterima oleh proses selanjutnya, seperti pekerjaan hydrotest, assembly, blasting dan painting, dapat diteruskan.

\section{Customer}

Customer dalam hal ini adalah pelanggan atau proses selanjutnya setelah proses pengelasan selesai. Dalam hal ini yang menjadi customer dari produksi pengelasan adalah bagian finishing atau painting. Namun perlu diketahui bahwa sebelum produk hasil pengelasan di antar ke bagian painting/finishing produk tersebut harus melalui inspeksi yang dilakukan oleh departemen quality control (QC). Salah satu inspeksi yang digunakan 
IV-6

QC adalah dengan menggunakan uji radiografi (Radiography Testing) atau disingkat sebagai RT. Dengan RT inilah diketahui apakah suatu las memiliki kecacatan atau tidak. Las yang cacat melebihi toleransi yang dibolehkan, harus diperbaiki atau dibuang cacatnya atau di-repair dan selanjutnya dilas kembali dan diinspeksi ulang.

\section{b. Penentuan CTQ (Critical to Quality)}

Kepuasan pelanggan dapat dipenuhi jika semua kriteria yang diinginkan oleh pelanggan dapat dicapai. Six sigma menegaskan bahwa keinginan pelanggan harus dipenuhi dengan cara mengukur dan menyempurnakan proses dan produk, dan karakteristik CTQ (Critical to Quality) dengan menetapkan ukuran untuk mengurangi defect yang mempengaruhi mutu produk dan mengurangi kepuasan pelanggan. Dari Tabel 5.1 yaitu tabel mengenai persentase defect terhadap produksi pengelasan yang direpresentasikan dalam jumlah film radiografi di departemen pengelasan PT Profab Indonesia, antara lain adalah:

1. Porosity

2. Slag Inclusion

3. Lack of Fusion

4. Undercut

5. Root Concavity

Setelah diketahui jenis-jenis defect pengelasan ini dan apa yang menjadi keinginan pelanggan terhadap mutu pengelasan perusahaan, serta dari data Voice of Customer yang didapat, maka perusahaan menyimpulkan untuk dapat meminimalisasikan weld defect (cacat las) dalam setiap produksi pengelasannya, karena dengan berkurangnya cacat las dalam produk pengelasan maka kualitas produk PT Profab Indonesia di mata pelanggan akan meningkat. Oleh sebab itu yang menjadi CTQ (Critical to Quality) perusahaan, yaitu faktor yang mempengaruhi terpenuhinya kebutuhan pelanggan adalah pengelasan yang bebas dari weld defects. CTQ selanjutnya akan menjadi elemen dalam mencari besarnya DPMO dan dari data di atas diketahui jumlah CTQ adalah 5. 


\begin{tabular}{|ll|}
\hline 1. & Peld Defects: \\
2. & Slag Inclusion \\
3. & Lack of Fusion \\
4. & Undercut \\
5. & Root Concavity \\
\hline
\end{tabular}

\section{Gambar 4.4. Critical To Quality (CTQ)}

\section{c. Critical to Process (CTP)}

Pada bagian ini akan ditentukan faktor-faktor apa saja yang mempengaruhi timbulnya atau meningkatnya jumlah pengelasan yang cacat sehingga dapat dengan segera dilakukan tindakan perbaikan terhadap faktor-faktor tersebut. Adapun beberapa faktor yang mempengaruhi proses minimalisasi weld defect, atau disebut juga sebagai Critical to Process (CTP) yaitu hal-hal yang mempengaruhi Critical to Quality (CTQ). Dengan demikian kita dapat lebih fokus lagi dalam melakukan perbaikan yang ada dalam proses produksi. Faktor-faktor yang memungkinkan atau mempengaruhi timbulnya defect pengelasan atau CTQ adalah:

1. Tenaga Kerja.

Kemampuan dari tenaga kerja, juru las, dalam proses produksi pengelasan di PT Profab Indonesia, merupakan salah satu faktor penting yang mempengaruhi kualitas produk yang diproduksi oleh perusahaan, karena masih secara garis besar banyak proses pengelasan yang menggunakan proses manual (SMAW). Hal ini membutuhkan ketekunan dan ketelitian yang lebih dalam proses pengelasan. Pelatihan dan pengujian juru las secara terus-menerus perlu dilakukan untuk meningkatkan ketrampilan dan keahlian juru las.

2. Mesin.

Mesin las merupakan salah satu faktor penting dalam proses pengelasan di PT Profab Indonesia. Mesin-mesin las ini harus salalu dalam kondisi yang prima agar proses pengelasan dapat berjalan dengan baik. 
IV-8

Pengetahuan tentang penggunaan mesin dengan baik oleh para pekerja (juru las) juga merupakan hal yang penting.

3. Supplier.

Supplier bahan baku dan kawat las juga memegang peranan yang penting dalam proses pengelasan. Perlakuan khusus untuk beberapa kawat las sesuai dengan yang disyaratkan oleh produsen kawat las, harus dilakukan, yaitu seperti perlakuan re-baking dan menjaga agar kawat las tetap panas terutama untuk pengelasan manual (SMAW). Kesalahan dalam penanganan bahan baku dan kawat las akan mempengaruhi kualitas dari hasil pengelasan dan menyebabkan terjadinya defect.

4. Tools.

Peralatan kerja (tools) seperti mesin grinda, jig chisel, wire brush, chipping hammer, merupakan alat-alat yang diperlukan dalam pengelasan terutama dalam usaha membersihkan pengelasan dari defects slags dan impurities. Kurangnya persediaan peralatan kerja atau tidak digunakannya peralatan kerja dengan benar akan mempengaruhi kualitas pengelasan dan menyebabkan terjadinya defect.

Maka keempat faktor tersebut dapat dikatakan sebagai Critical to Process (CTP) terhadap proses pengelasan, dimana sedikit dan banyaknya cacat las dalam setiap produksi pengelasan bergantung pada keempat faktor tersebut dan pada akhirnya akan mempengaruhi kepuasan pelanggan.

\subsection{Mengukur (Measure)}

Pengukuran merupakan fase kedua dari konsep Six Sigma. Dalam tahap ini akan dilakukan beberapa analisis untuk menentukan bagaimana kondisi proses pengelasan yang sedang berjalan serta masalah-masalah apa yang dihadapi sebelum dilakukannya perbaikan dengan menggunakan metodologi Six Sigma. Tahap ini menggunakan acuan Critical to Quality (CTQ) yang telah didefinisikan pada tahap define sebelumnya.

Tahap measure memegang peranan yang sangat penting dalam peningkatan kualitas karena dapat mengetahui kinerja perusahaan melalui perhitungan data yang dijadikan sebagai dasar untuk melakukan analisis dan perbaikan. Dalam DMAIC 
terdapat dua konsep pengukuran yaitu konsep pengukuran kinerja produk dan konsep pengukuran kinerja proses.

a. Pengukuran Kinerja Proses.

Untuk mengukur kinerja proses dapat dilakukan dengan beberapa perhitungan yaitu:

1. Menghitung nilai tengah dan batas kontrol pada proses serta penggambaran peta kontrol dari proses tersebut. Dari data-data ini akan didapat angka produktivitas masing-masing pekerja atau karyawan.

2. Menghitung kapabilitas proses (process capability) untuk mengetahui seberapa baik proses dapat memproduksi pengelasan yang bebas dari cacat. Data pengelasan ini diperoleh dari laporan bulanan defect rate pengelasan di PT Profab Indonesia pada bulan Juni 2016.

b. Pengukuran Kinerja Produk.

Pengukuran kinerja produk dapat dilakukan dengan:

1. Menghitung DPMO (defect per million opportunities), yaitu mengidentifikasi berapa banyak defect yang terjadi dalam satu juta peluang dan menghitung nilai sigma produk pada setiap proses.

2. Menghitung COPQ (Cost of Poor Quality), yaitu biaya yang timbul akibat terjadinya cacat (defect) dalam produk pengelasan. Biaya yang terjadi sebagai akibat kerja ulang (reworks) berupa biaya bahan dan alatalat kerja, biaya tenaga kerja, dan biaya pelatihan ulang (re-training).

Data-data yang digunakan untuk pembuatan peta kendali ini adalah datadata jumlah output yaitu jumlah film radiografi yang dihasilkan selama bulan Juni 2016 untuk produk pengelasan perusahaan.

Tabel 4.1. Data Jumlah Output dan Defect

\begin{tabular}{|c|c|c|}
\hline Minggu & Output & Jumlah Defect \\
\hline Ke-I & 221 & 8 \\
\hline Ke-II & 245 & 6 \\
\hline Ke-III & 265 & 7 \\
\hline Ke-IV & 256 & 5 \\
\hline Total & 987 & 26 \\
\hline
\end{tabular}


Berikut di bawah ini adalah perhitungan proporsi cacat dalam tiap minggu inspeksinya.

Tabel 4.2. Data Proporsi Defect Bulan Juni 2016

\begin{tabular}{|c|c|c|c|}
\hline Minggu & Output & Jumlah Defect & Proporsi \\
\hline Ke-I & 221 & 8 & $3,62 \%$ \\
\hline Ke-II & 245 & 6 & $2,45 \%$ \\
\hline Ke-III & 265 & 7 & $2,64 \%$ \\
\hline Ke-IV & 256 & 5 & $1,95 \%$ \\
\hline Total & 987 & 26 & $2,63 \%$ \\
\hline
\end{tabular}

Dari table di atas dapat dilihat bahwa total jumlah cacat selama bulan Juni 2016 adalah sebanyak 26 defect. Di bawah ini adalah tabel rekapitulasi defect dan jenis-jenisnya.

Tabel 4.3. Tabel Rekapitulasi Defect Bulan Juni 2016

\begin{tabular}{|c|c|c|c|c|}
\hline No & Jenis Defect & Jumlah Defect & Total Defect & Prosentase \\
\hline 1 & Slag Inclusion & 7 & 26 & $26,92 \%$ \\
\hline 2 & Lack of Fusion & 7 & 26 & $26,92 \%$ \\
\hline 3 & Porosity & 7 & 26 & $26,92 \%$ \\
\hline 4 & Undercut & 5 & 26 & $19,23 \%$ \\
\hline 5 & Root Concavity & 0 & 26 & $0,00 \%$ \\
\hline & Total & 26 & & \\
\hline
\end{tabular}

Dari data rekapitulasi di atas didapat bahwa jenis defect slag inclusion menjadi defect yang paling banyak ditemukan dalam inspeksi pengelasan.

Di bawah ini adalah cara penentuan DPMO (Defect Per Million Opportunities) dan level Sigma.

1) Menghitung DPU (Defect per Unit) dalam hal ini adalah jumlah defect per minggu.

$$
D P U=\frac{\text { Total Defect }}{\text { Total Output } x C T Q}
$$


Contoh: $D P U=\frac{8}{(221 \times 5)}=0,00724$

2) Menghitung DPMO (Defect per Million Opportunities)

$D P M O=\frac{\text { Total Defect }}{\text { Total Output } \times C T Q} \times 1.000 .000$

Contoh: $D P M O=\frac{8}{(221 \times 5)} X 1.000 .000=7239,82$

3) Menghitung prosentase Yield

Yield $=100 \%-\left(\frac{\text { Total Defect }}{\text { Total Output } \times C T Q} \times 100 \%\right)$

Contoh: Yield $=100 \%-\left(\frac{8}{221 \times 5} \times 100 \%\right)$

$$
\text { Yield }=100 \%-0,724 \%=99,28 \%
$$

4) Mengkonversikan hasil perhitungan DPMO dengan tabel Six Sigma atau kalkulator Six Sigma untuk mendapatkan hasil nilai sigma. Untuk memperjelas hasil DPMO dan level Sigma dapat dilihat pada tabel berikut.

Tabel 4.4. Perhitungan Nilai Sigma

\begin{tabular}{|c|c|c|c|c|c|c|}
\hline Minggu & Output & $\begin{array}{c}\text { Jumlah } \\
\text { Defect }\end{array}$ & DPU & Yield & DPMO & $\begin{array}{c}\text { Nilai } \\
\text { Sigma }\end{array}$ \\
\hline Ke-I & 221 & 8 & 0,00724 & $99,28 \%$ & 7239,82 & 4,05 \\
\hline Ke-II & 245 & 6 & 0,00489 & $99,51 \%$ & 4897,96 & 4,15 \\
\hline Ke-III & 265 & 7 & 0,00528 & $99,47 \%$ & 5283,02 & 4,15 \\
\hline Ke-IV & 256 & 5 & 0,00390 & $99,61 \%$ & 3906,25 & 4,15 \\
\hline & & & \multicolumn{7}{|c|}{ Rata-rata } & $\mathbf{5 2 6 8 , 4 9}$ & $\mathbf{4 , 1 0}$ \\
\hline
\end{tabular}

Dari hasil perhitungan pada Tabel 5.4 di atas, bagian produksi pengelasan PT Profab Indonesia memiliki tingkat rata-rata Sigma (Sigma level) sebesar 4,10 dengan nilai DPMO sebesar 5268,49. Nilai ini lebih baik daripada kondisi sebelumnya (pada bulan Oktober - 
IV-12

Nopember 2015) yaitu nilai DPMO sebesar 31001,79 dan nilai Sigma sebesar 3,32 (Lihat Tabel 3,32).

\subsection{Menganalisis (Analyze)}

Tahap analyze merupakan tahap berikutnya setelah tahap mengukur (measure). Pada tahap ini dilakukan analisis dan identifikasi mengenai sebab timbulnya masalah sehingga dapat melakukan tindakan penanggulangan terhadap sebab-sebab yang ada. Tools Six Sigma yang digunakan pada fase ini adalah diagram Pareto dan Fishbone. Hasil akhir yang ingin diperoleh dari tahap ini adalah berupa informasi atau pernyataan mengenai penyebab terjadinya cacat dalam pengelasan.

a. Analisis Diagram Pareto

Data yang diolah untuk mengetahui prosentase defect berdasarkan jenisnya dihitung dengan menggunakan rumus sebagai berikut:

$$
\% \text { Jenis Defect }=\frac{\text { Jumlah Defect sejenis }}{\text { Jumlah Keseluruhan Defect }} \times 100 \%
$$

Dari rumus di atas kemudian didapat data sebagai berikut:

Tabel 4.5. Analisis Jenis Defect

\begin{tabular}{|l|c|c|c|c|c|}
\cline { 2 - 6 } \multicolumn{1}{c|}{} & Lack of Fusion & Porosity & $\begin{array}{c}\text { Slag } \\
\text { Inciusion }\end{array}$ & Undercut & $\begin{array}{c}\text { Root } \\
\text { Concavity }\end{array}$ \\
\hline Defect & 7 & 7 & 7 & 5 & 0 \\
\hline Total defect & 26 & 26 & 26 & 26 & 26 \\
\hline Prosentase & $\mathbf{2 6 , 9 2 \%}$ & $\mathbf{2 6 , 9 2 \%}$ & $\mathbf{2 6 , 9 2 \%}$ & $\mathbf{1 9 , 2 3 \%}$ & $\mathbf{0 , 0 0 \%}$ \\
\hline
\end{tabular}

Dari tabel di atas didapat terjadinya penyebaran jumlah defect pada jenis-jenis defect lack of fusion, porosity, slag inclusion dan undercut, dan hal ini lebih baik dari kondisi sebelumnya (lihat Tabel 2.2).

b. Analisis Diagram Sebab Akibat

Diagram sebab akibat memperlihatkan hubungan antara permasalahan yang dihadapi dengan kemungkinan penyebabnya serta faktor-faktor yang mempengaruhinya. Adapun faktor-faktor yang mempengaruhi dan menjadi penyebab kerusakan hasil las secara umum dapat digolongkan sebagai berikut:

a) Man (manusia)

Para juru las yang melakukan pekerjaan dalam proses pengelasan. 
b) Material (bahan baku)

Segala sesuatu yang dipergunakan oleh perusahaan sebagai komponen dalam proses pengelasan seperti bahan baku dan bahan penunjang yang lain.

c) Machine (mesin)

Mesin-mesin dan berbagai peralatan yang digunakan dalam proses produksi pengelasan.

d) Method (metode)

Instruksi kerja atau perintah kerja yang harus diikuti dalam proses produksi pengelasan.

e) Environment (lingkungan)

Keadaan sekitar perusahaan secara langsung atau tidak mempengaruhi perusahaan secara umum dan mempengaruhi proses produksi atau pengelasan secara khusus. Setelah diketahui jenis-jenis cacat las yang terjadi, maka PT Profab Indonesia perlu mengambil langkah-langkah perbaikan untuk mencegah timbulnya kerusakan yang serupa. Hal penting yang harus dilakukan dan ditelusuri adalah mencari penyebab terjadinya cacat las tersebut, maka digunakanlah diagram sebab-akibat atau yang disebut juga dengan fishbone chart. Berkaitan dengan analisis defect pengelasan secara statistik, diagram sebab-akibat digunakan untuk mengetahui faktor-faktor yang menyebabkan adanya masalah kualitas. Untuk lebih jelasnya dapat dilihat cause-effect diagram di bawah ini: 


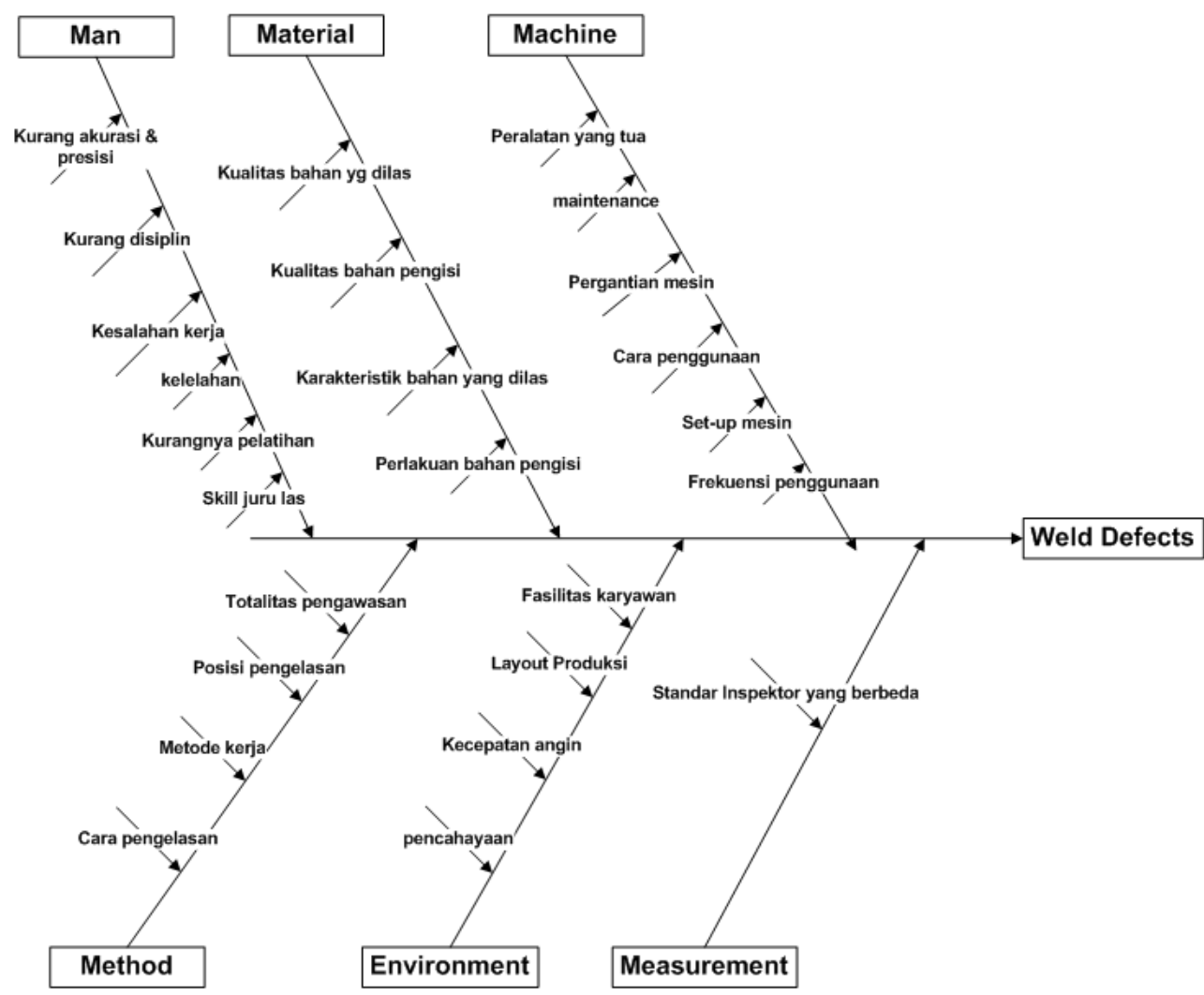

Gambar 4.5. Cause-Effect Diagram

Dari cause effect diagram di atas dapat dilihat faktor-faktor penyebab potensial dari weld defect dimana diantaranya adalah kesalahan kerja, metode kerja dan kualitas bahan pengisi. Faktor-faktor tersebut adalah:

a) Machine (mesin)

Mesin memegang peranan penting dalam kegiatan produksi karena tanpa mesin produksi tidak dapat dilakukan. Adapun faktor yang berpengaruh dalam kinerja kualitas produksi jika ditinjau dari mesin adalah:

- Useful life tiap mesin berbeda-beda sesuai dengan waktu pertama kali mesin masuk perusahaan atau pengadaan mesin.

- Frekuensi penggunaan mesin pada unit welding cukup tinggi terhitung dari jam 07.00 - 17.00 WIB belum lagi bila pekerja lembur.

- Set up mesin yang dilakukan operator tidak sama walaupun SOP (Standard Operating Procedure) sudah dibakukan. 
- Cara penggunaan mesin untuk setiap operator (juru las) berbeda-beda sesuai dengan pengalaman kerja dan hasil training operator selama bekerja di PT. Profab Indonesia atau perusahaan-perusahaan sebelumnya.

- Pergantian mesin perusahaan didasarkan pada perhitungan umur mesin dan kapasitas kerja mesin, apabila kondisi mesin sering mengalami breakdown tentu harus dilakukan pergantian mesin segera.

- Sistem manajemen perawatan PT. Profab Indonesia cukup baik tetapi perlu ditingkatkan dengan menerapkan TPM (Total Productive Maintenance). Dengan konsep ini perawatan tidak hanya dilakukan oleh tim maintenance tetapi juga dapat dilakukan oleh pekerja lain yang terlibat dalam operasi pengelasan di perusahaan.

- Sistem jidoka adalah mengganti peralatan konvesional menjadi automatis atau automation industry. Sistem jidoka ini dapat mengurangi tingkat defect pengelasan karena manusia (juru las) hanya sebagai pengendali saja, keseluruhan operasi dilakukan oleh mesin sehingga hasil produk pengelasan dapat diandalkan.

b) Material (bahan baku)

Material juga menjadi penyebab terjadinya defect pengelasan. Adapun penyebab kecacatan las jika ditinjau dari material antara lain adalah:

- Bahan baku/komponen yang dipakai bervariasi sesuai dengan permintaan konsumen (demand order).

- Unit pemasok (supplier) bahan baku/komponen dari berbagai lokasi dan berbagai karakteristik bahan.

- Kesesuaian bahan baku terhadap proses pengelasan menjadi faktor penting dalam pengelasan. Antara plat, pipa dan profil baja yang siap difabrikasi mempunyai karakteristik yang berbeda-beda dan hal ini mempengaruhi hasil pengelasan.

- Pengawasan terhadap kualitas bahan baku harus benar-benar terjaga sehingga nantinya defect pada pengelasan dapat dikurangi atau bahkan dihilangkan. 
c) Man (manusia)

- Disiplin juru las menjadi peranan penting dalam upaya pengurangan defect pengelasan, bukan saja disiplin kehadiran tetapi juga totalitas disiplin yang maksimal.

- Akurasi dan presisi pada saat proses pengelasan dari tiap-tiap operator berbeda-beda. Proses pengelasan yang dilakukan selama ini menggunakan metode manual (SMAW).

- Setiap juru las yang telah diberi pelatihan harus memahami dan mengimplementasikan aturan dan cara kerja pengelasan yang benar di perusahaan.

- Skill operator tidak sama sehingga perlunya pengawasan yang dapat meningkatkan motivasi pekerja.

- Pelatihan karyawan/operator perlu dilakukan pada setiap periode kerja.

- Kelelahan kerja mempengaruhi terjadinya produk defect karena proses pengelasan dilakukan tidak ergonomis. Jam kerja lembur yang panjang mengurangi ketahanan tubuh operator hal ini mengakibatkan efektifitas kerja menurun.

d) Method (metode)

- Totalitas pengawasan bagian inspeksi akan menurun terlebih pada saat jam kerja lembur malam. Faktor lain yang menentukan adalah faktor ketelitian yang tinggi.

- Posisi pengelasan tiap operator tentu tidak sama sesuai dengan kenyamanan operator pada tiap kali mengelas.

- Metode kerja yang mengacu pada metode kerja sistem manajeman QHSE (Quality, Health, Safety and Environment).

- Cara pengelasan tiap operator tidak sama walaupun pada dasarnya samasama mengelas logam. Posisi pengelasan cukup menjadi acuan hasil produksi nantinya. Bahan yang tipis akan mudah mencair terkena panas busur api las daripada bahan yang tebal dan sebagainya.

e) Environment (Lingkungan kerja) 
- Fasilitas karyawan merupakan sarana pendukung selama operator melakukan operasi produksi pengelasan. Pemakaian fasilitas karyawan ditujukan untuk memenuhi standar keselamatan kerja operator. Alat pelindung diri operator bisa saja menghalangi jarak pandang mata operator terhadap obyek yang akan dilas.

- Apabila ditinjau dari layout produksi PT. Profab Indonesia hal ini sesuai dengan product layout. Konsep ini cukup bagus tetapi dalam perkembangannya dapat mengurangi efisiensi gerakan, dimana material handling selama proses produksi cukup jauh.

- Suhu ruangan kerja pengelasan tentu sangat panas seperti bengkelbengkel pengelasan pada umumnya.

- Lighting di lantai produksi pengelasan menggunakan lampu halogen putih. Tetapi lokasi lampu cukup jauh dari tempat kerja dan operator menggunakan kacamata las maka kemungkinan terjadinya cacat las cukup tinggi.

f) Measurement (Pengukuran)

- Standarisasi pengukuran berbeda-beda berdasarkan KPI dari sistem manajemen mutu (QMS) adalah 10\%, namun banyak pekerja belum mengetahuinya.

Berdasarkan paparan di atas dapat disimpulkan faktor potensial terjadinya kecacatan pengelasan bergantung pada hal-hal di atas.

\subsection{Meningkatkan (Improve)}

Setelah mengetahui akar penyebab tinggingnya kecacatan las, maka langkah selanjutnya adalah menentukan suatu usulan perbaikan untuk tiap penyebab yang ada. Penentuan usulan perbaikan dilakukan dengan melakukan brainstorming bersama foreman, supervisor dan welding manager. Brainstorming terserbut bertujuan untuk mendapatkan usulan perbaikan yang tepat dan dapat diterapkan oleh perusahaan sehingga dapat mengurangi prosentase cacat pada proses pengelasan. Dari akar-akar penyebab tersebut kemudian dimasukkan ke dalam rumusan perbaikan 5W-1H, Cause-effect Diagram, dan FMEA. Pada proses improve terdapat beberapa tahap yang antara lain adalah: 


\section{a. Penggunaan konsep 5W-1H}

Konsep ini ditujukan untuk mendefinisikan jenis cacat yang akan dicarikan usulan perbaikannya. Aplikasi $5 \mathrm{~W}-1 \mathrm{H}$ dilakukan pada tiap karakteristik kecacatan. Untuk lebih jelasnya dapat dilihat pada table di bawah ini.

Tabel 4.6. Analisis 5W-1H

\begin{tabular}{|c|c|c|}
\hline Penyebab Cacat & $5 W-1 H$ & Deskripsi \\
\hline \multirow[t]{6}{*}{ Manusia } & What (Apa) & Operasi Pengelasan \\
\hline & Why (Kenapa) & Kurang training \\
\hline & Where (Dimana) & Lapangan (yard) \\
\hline & When (Kapan) & Shift malam \\
\hline & Who (Siapa) & Juru Las \\
\hline & How (Bagaimana) & $\begin{array}{l}\text { Kurang melakukan } \\
\text { pembersihan slag } \\
\text { selama pengelasan }\end{array}$ \\
\hline \multirow[t]{6}{*}{ Mesin } & What (Apa) & Mesin Pengelasan \\
\hline & Why (Kenapa) & $\begin{array}{l}\text { Kondisi tua dan tidak } \\
\text { terawatt }\end{array}$ \\
\hline & Where (Dimana) & Lapangan (yard) \\
\hline & When (Kapan) & Shift malam \\
\hline & Who (Siapa) & Tenaga Mekanik \\
\hline & How (Bagaimana) & $\begin{array}{l}\text { Tidak ada perawatan } \\
\text { preventif (preventive } \\
\text { maintenance) }\end{array}$ \\
\hline
\end{tabular}


IV-19

\begin{tabular}{|l|c|l|}
\hline Lingkungan & What (Apa) & Operasi Pengelasan \\
\hline & Why (Kenapa) & $\begin{array}{l}\text { Kurang terang dan } \\
\text { banyak angina }\end{array}$ \\
\hline & Where (Dimana) & Lapangan (yard) \\
\hline & When (Kapan) & Shift malam \\
\hline & Who (Siapa) & Foreman/Supervisor \\
\hline & & $\begin{array}{l}\text { Jumlah lampu kurang, } \\
\text { tidak ada proteksi angin } \\
\text { (windshield) }\end{array}$ \\
\hline
\end{tabular}

\section{b. Pengukuran}

1) Peluang: menurunkan jumlah cacat las dengan menerapkan sistem kontrol yang lebih teliti.

2) Kerusakan: dari 3903 film yang dilakukan pemeriksaan selama bulan Oktober dan Nopember 2015, terdapat 605 film berisi defect.

3) Proses kapabilitas saat ini yang dicapai pada PT Profab Indonesia ditunjukkan dengan nilai DPMO dan nilai Sigma pada bulan Oktober - Nopember 2015.

Tabel 4.7. Proses Kapabilitas

Sumber: Data Primer PT Profab Indonesia yang telah diolah

\begin{tabular}{|c|c|c|}
\hline Week & DPMO & Nilai Sigma \\
\hline 1 & 38150,29 & 3,27 \\
\hline 2 & 52546,92 & 3,12 \\
\hline 3 & 40909,09 & 3,24 \\
\hline 4 & 43950,62 & 3,21 \\
\hline
\end{tabular}


IV-20

\begin{tabular}{|c|c|c|}
\hline 5 & 22670,81 & 3,50 \\
\hline 6 & 29395,35 & 3,39 \\
\hline 7 & 12765,96 & 3,73 \\
\hline 8 & 22222,22 & 3,51 \\
\hline Total & $\mathbf{3 1 0 0 1 , 7 9}$ & $\mathbf{3 , 3 2}$ \\
\hline
\end{tabular}

Berdasarkan table 4.7 di atas didapat bahwa total DPMO adalah sebesar 31001,79 dan nilai Sigma sebesar 3,32.

\section{c. Rekomendasi Perbaikan}

1) Rekomendasi pada bagian pemeliharaan mesin.

a) Perbaikan mesin yang rusak dan melakukan perawatan terhadap mesin secara lebih intensif dan terus menerus atau berkala.

b) Melakukan setting mesin secara berkala berdasarkan SOP (Standard Operating Procedure) dan selalu melakukan pengecekan mesin setiap waktu.

c) Melakukan prinsip TPM (Total Productive Maintenance).

d) Menerapkan sistem Jidoka (otomasi)

2) Rekomendasi pada bagian material.

a) Melakukan pemeriksaan dan pengendalian bahan baku secara teliti, termasuk bahan pengisi pengelasan (weld consumable).

b) Melakukan treatment bahan baku dan bahan pengisi pengelasan sesuai dengan rekomendasi pabrik atau pembuat.

3) Rekomendasi pada personil pengelasan

a) Disiplin pra-operasi, saat operasi dan paska-operasi pengelasan (before, during dan after welding).

b) Mengikuti pelatihan (training) dengan baik dan kemudian diterapkan pada saat melakukan pekerjaan pengelasan. 
IV-21

c) Melakukan pembersihan tiap lapisan (layer) las selama pengelasan untuk mencegah terperangkapnya slag dalam layer las yang menimbulkan defect pengelasan.

d) Menjaga kesehatan dan stamina agar tetap fokus pada saat melakukan pengelasan.

4) Rekomendasi pada metode

a) Totalitas pengawasan baik ketika jam lembur atau tidak

b) Menerapkan hasil training dengan penuh kesadaran pribadi.

5) Rekomendasi pada lingkungan

a) Pemakaian dan penggunaan fasilitas kerja juru las secara baik dan benar.

b) Penerangan perlu ditambah untuk memperjelas jarak pandang operator terhadap benda/obyek yang akan dilas, terutama pada saat shift malam.

c) Yard layout perlu disesuaikan dengan kebutuhan kerja dan proyek.

d) Untuk menstabilkan suhu ruangan dan suhu tubuh juru las/operator las terutama dalam ruangan kerja yang terbatas dan sempit diperlukan kipas angin atau exhaust fan.

6) Rekomendasi pada pengukuran

a) Menerapkan sistem quality planning dimana setiap QC dan personil supervisi memahami kriteria keberterimaan (acceptance criteria) dari hasil pengelasan.

\section{d. Hasil Analisis}

1) Kurangnya disiplin dalam melakukan pembersihan saat operasi las adalah faktor utama terjadinya produk las yang cacat (weld defect).

2) Kurangnya pengawasan dan terbatasnya alat-alat kerja terutama alat-alat pembersihan las seperti grinda, pahat, palu chipping dan sebagainya membuat juru las kesulitan dalam melakukan pembersihan antar lapisan las (interpass cleaning).

3) Kurangnya perawatan mesin las juga menyebabkan mesin las menjadi tidak stabil sehingga menghasilkan hasil las yang tidak standar dan cacat.

4) Kurangnya pengawasan dalam pemilihan, pemeriksaan dan pemeliharaan bahan baku dan bahan pengisi las juga mempengaruhi hasil akhir pengelasan. 
IV-22

5) Kurangnya pengamatan yang dilakukan sebelum, selama dan setelah pengelasan juga dapat mempengaruhi hasil inspeksi pengelasan dengan metode radiografi.

6) Supervisor dan foreman kurang melakukan pengawasan (control) terhadap pekerjaan anak buahnya yaitu juru las atau operator las.

7) Ketrampilan (skill) juru las yang masih perlu ditingkatkan dengan pelatihanpelatihan.

\section{e. Tindakan perbaikan yang dilakukan}

1) Meningkatkan pengawasan terhadap hasil pekerjaan juru las baik sebelum, selama dan setelah melakukan pengelasan.

2) Menambah alat-alat yang menunjang pembersihan las, agar setiap juru las mempunyai alat-alat yang cukup untuk melakukan interrun cleaning.

3) Menambah tenaga teknisi perawatan (maintenance) yang mencek setiap mesin las dan melakukan program perawatan preventif (preventive maintenance) agar tidak terjadi mesin yang rusak dan pekerjaan las yang terbengkalai.

4) Melakukan pengawasan intensif terhadap pemeliharaan dan penjagaan bahan baku yang akan dilas dan bahan pengisi las, sehingga mutu bahan dapat tetap terjamin dan tidak mempengaruhi mutu pengelasan.

5) Menekankan agar QC Inspector dapat melakukan perannya lebih giat lagi dalam melakukan pengawasan terhadap juru las dan hasil pengelasannya, apabila kinerja dan workmanship dari juru las terbukti berada di bawah standar yang ditentukan, maka QC Inspector dapat melaporkannya ke Supervisor atau Manajer bidang produksi pengelasan untuk dilakukan penindakan atau pemberian sanksi kerja.

6) Menekankan pada supervisor dan foreman operator las agar tidak segan dalam memberikan peringatan atau sanksi administratif kepada juru las atau operator las yang bekerja di bawah standar, atau yang melakukan kesalahan teknis baik sengaja ataupun tidak, serta yang mempengaruhi hasil las dan menyebabkan pekerjaan repair atau re-work, yang secara materi/biaya merugikan pihak perusahaan. 
IV-23

7) Melakukan pelatihan-pelatihan rutin baik secara formal ataupun tidak terhadap prinsip-prinsip pengelasan yang baik dan benar sehingga juru las/operator las dapat menghasilkan las-lasan yang bebas dari cacat (defect).

\section{f) Penggunaan metode FMEA}

Metode analisis FMEA adalah analisis yang digunakan untuk mengetahui atau mengamati apakah suatu tindak kegagalan (failure) dapat dianalisis atau diukur sehingga dapat diantisipasi, dimitigasi ataupun dicegah baik tingkat kegagalannya ataupun efek negatif yang timbul sebagai faktor output-nya. Sebenarnya ada kemiripan antara metode FMEA dengan analisis diagramdiagram sebelumnya seperti diagram sebab akibat, diagram pareto dan konsep $5 \mathrm{~W}-1 \mathrm{H}$ dalam rangka mencari akar permasalahan (root cause) dan usulan perbaikannya (proposed corrective actions), hanya saja dengan menggunakan FMEA kita dapat mengetahui bobot atau nilai dari suatu permasalahan dan membuat bobot prioritas masalah. Dalam FMEA tindakan perbaikan akan dimulai dari nilai prioritas yang paling tinggi dan terus ke masalah-masalah dengan nilai prioritas di bawahnya.

FMEA menurut Mc Dermott dan koleganya (Mc Dermott, 2009: h. 10), memberikan tiga faktor evaluasi resiko yaitu faktor evaluasi resiko Severity (keparahan), Occurrence (kejadian) dan Detection (deteksi). Ketiga faktor evaluasi resiko ini kemudian membentuk yang namanya nomor prioritas resiko atau Risk Priority Number (RPN), RPN ini diperoleh dengan mengalikan nilainilai Severity, Occurrence dan Detection secara bersamaan atau bila dirumuskan akan menjadi S x O x D = RPN. Semakin tinggi nilai RPN maka semakin tinggi pula resiko yang ditimbulkan suatu masalah dan semakin tinggi juga dampak yang ditimbulkan masalah itu terhadap kualitas produk atau proses yang dilakukan, sehingga penangan atau perbaikannya harus disegerakan.

Berikut ini adalah rincian dari masing-masing faktor evaluasi resiko yang membentuk RPN:

1) Severity (S)

Menunjukkan seberapa parah suatu masalah dan seberapa besar masalah itu mempengaruhi kualitas produk atau proses. Hal ini ditandai dengan nilai 1 
IV-24

sampai 10, dimana nilai 1 adalah yang paling ringan atau kecil tingkat keparahannya, sedangkan nilai 10 adalah yang paling tinggi atau paling berat tingkat keparahannya.

2) Occurrence $(\mathrm{O})$

Menunjukkan seberapa sering masalah itu terjadi atau akan terjadi dalam satu waktu proses produksi. Hal ini ditandai dengan nilai 1 sampai 10, dimana nilai 1 adalah yang paling jarang terjadi dan nilai 10 adalah yang paling sering terjadi.

1) Detection (D)

Menunjukkan seberapa mudah suatu persoalan / masalah dideteksi atau diketahui dalam suatu proses produksi. Hal ini ditandai dengan nilai 1 sampai 10, dimana nilai 1 adalah yang paling mudah dideteksi atau diketahui dan nilai 10 adalah permasalahan yang paling sulit untuk dideteksi atau diprediksi sebelumnya.

Berikut ini adalah analisis FMEA yang dilakukan PT. Profab Indonesia dalam mencari solusi terhadap permasalahan defect rate-nya (lihat Tabel $4.8 \mathrm{di}$ bawah)

Tabel 4.8. Analisis FMEA

\begin{tabular}{|c|c|c|}
\hline $\mathbf{I}$ & Manusia & \\
\hline & Mode Kegagalan & 1. Pekerja tidak trampil \\
\hline & & 2. Pekerja tidak berkualifikasi \\
\hline & & 3. Pekerja malas \\
\hline & & 4. Pekerja kurang tanggung jawab \\
\hline & Akibat Kegagalan & 1. Hasil pengelasan tidak bagus \\
\hline & & $\begin{array}{l}\text { 2. Timbulnya banyak defect terutama slag } \\
\text { inclusion }\end{array}$ \\
\hline & Nilai Severity & 8 \\
\hline & Penyebab & Skill pekerja di bawah standar \\
\hline & Nilai Occurance & 7 \\
\hline & Pengawasan & Foreman dan Leading hand \\
\hline
\end{tabular}


IV-25

\begin{tabular}{|c|c|c|}
\hline & Nilai Detection & 5 \\
\hline & $\begin{array}{l}\text { RPN sebelum } \\
\text { perbaikan }\end{array}$ & $8 \times 7 \times 5=280$ \\
\hline & $\begin{array}{l}\text { Tindakan } \\
\text { korektif/mitigasi }\end{array}$ & $\begin{array}{l}\text { 1. Pekerja diberikan training tambahan teori } \\
\text { dan praktek }\end{array}$ \\
\hline & & $\begin{array}{l}\text { 2. Pekerja yang malas diberikan surat } \\
\text { peringatan/warning. }\end{array}$ \\
\hline & Penanggung Jawab & Foreman dan Leading hand \\
\hline & Tanggal Selesai & 31-Mei-2016 \\
\hline & Status Tindakan & Selesai \\
\hline & Nilai Severity & 3 \\
\hline & Nilai Occurance & 2 \\
\hline & Nilai Detection & 1 \\
\hline & $\begin{array}{l}\text { RPN setelah } \\
\text { perbaikan }\end{array}$ & $3 \times 2 \times 1=6$ \\
\hline II & Mesin dan Alat & \\
\hline & Mode Kegagalan & 1. Mesin sering rusak \\
\hline & & 2. Mesin kurang perawatan \\
\hline & Akibat Kegagalan & 1. Hasil pengelasan tidak bagus \\
\hline & & 2. Timbulnya banyak defect terutama porosity \\
\hline & Nilai Severity & 7 \\
\hline & Penyebab & Mesin tidak stabil \\
\hline & Nilai Occurance & 5 \\
\hline & Pengawasan & Maintenance Supervisor \\
\hline & Nilai Detection & 4 \\
\hline & $\begin{array}{l}\text { RPN sebelum } \\
\text { perbaikan }\end{array}$ & $7 \times 5 \times 4=140$ \\
\hline & $\begin{array}{l}\text { Tindakan } \\
\text { korektif/mitigasi }\end{array}$ & 1. Memperbaiki mesin yang rusak \\
\hline
\end{tabular}


IV-26

\begin{tabular}{|c|c|c|}
\hline & & $\begin{array}{l}\text { 2. Mengganti mesin yang rusak dengan yang } \\
\text { baru. }\end{array}$ \\
\hline & Penanggung Jawab & Maintenance Supervisor \\
\hline & Tanggal Selesai & 31-Mei-2016 \\
\hline & Status Tindakan & Selesai \\
\hline & Nilai Severity & 3 \\
\hline & Nilai Occurance & 2 \\
\hline & Nilai Detection & 2 \\
\hline & $\begin{array}{l}\text { RPN setelah } \\
\text { perbaikan }\end{array}$ & $3 \times 2 \times 2=12$ \\
\hline III & Metode Kerja & \\
\hline & Mode Kegagalan & $\begin{array}{l}\text { 1. Proses pengelasan menggunakan sistem } \\
\text { manual. }\end{array}$ \\
\hline & & $\begin{array}{l}\text { 2. Kurang pelindung angina menyebabkan } \\
\text { kontaminasi udara. }\end{array}$ \\
\hline & Akibat Kegagalan & 1. Banyak defect pengelasan berupa porosity \\
\hline & Nilai Severity & 8 \\
\hline & Penyebab & Tidak ada pelindung weld pool dari udara luar \\
\hline & Nilai Occurance & 5 \\
\hline & Pengawasan & Welding Supervisor \\
\hline & Nilai Detection & 5 \\
\hline & $\begin{array}{l}\text { RPN sebelum } \\
\text { perbaikan }\end{array}$ & $8 \times 5 \times 5=200$ \\
\hline & $\begin{array}{l}\text { Tindakan } \\
\text { korektif/mitigasi }\end{array}$ & $\begin{array}{l}\text { 1. Menggunakan workshop tertutup atau } \\
\text { kanopi sehingga pengaruh lingkungan luar } \\
\text { berkurang. }\end{array}$ \\
\hline & Penanggung Jawab & Welding Supervisor \\
\hline & Tanggal Selesai & 31-Mei-2016 \\
\hline & Status Tindakan & Selesai \\
\hline & Nilai Severity & 3 \\
\hline
\end{tabular}


IV-27

\begin{tabular}{|c|c|c|}
\hline & Nilai Occurance & 2 \\
\hline & Nilai Detection & 1 \\
\hline & $\begin{array}{l}\text { RPN setelah } \\
\text { perbaikan }\end{array}$ & $3 \times 2 \times 1=6$ \\
\hline \multirow[t]{18}{*}{ IV } & \multicolumn{2}{|l|}{ Bahan Pengisi Las } \\
\hline & Mode Kegagalan & 1. Bahan pengisi las yang kurang bagus \\
\hline & & $\begin{array}{l}\text { 2. Bahan pengisi las yang tidak dilakukan } \\
\text { perilaku sebelumnya }\end{array}$ \\
\hline & Akibat Kegagalan & 1. Banyak defect pengelasan berupa porosity \\
\hline & Nilai Severity & 7 \\
\hline & Penyebab & Bahan pengisi las rusak atau basah \\
\hline & Nilai Occurance & 4 \\
\hline & Pengawasan & Procurement staf dan Storeman \\
\hline & Nilai Detection & 5 \\
\hline & $\begin{array}{l}\text { RPN sebelum } \\
\text { perbaikan }\end{array}$ & $7 \times 4 \times 5=140$ \\
\hline & $\begin{array}{l}\text { Tindakan } \\
\text { korektif/mitigasi }\end{array}$ & $\begin{array}{l}\text { 1. Membeli bahan pengisi las dari merek yang } \\
\text { reputable. } \\
\text { 2. Melakukan treatment pada kawat las sesuai } \\
\text { dengan rekomendasi maker. }\end{array}$ \\
\hline & Penanggung Jawab & Procurement staf dan Storeman \\
\hline & Tanggal Selesai & 31-Mei-2016 \\
\hline & Status Tindakan & Selesai \\
\hline & Nilai Severity & 2 \\
\hline & Nilai Occurance & 2 \\
\hline & Nilai Detection & 2 \\
\hline & $\begin{array}{l}\text { RPN setelah } \\
\text { perbaikan }\end{array}$ & $2 \times 2 \times 2=8$ \\
\hline $\mathbf{V}$ & Pengukuran & \\
\hline & Mode Kegagalan & 1. Proses pengukuran kurang efektif \\
\hline
\end{tabular}


IV-28

\begin{tabular}{|c|c|c|}
\hline & Akibat Kegagalan & 1. Banyak defect pengelasan berupa porosity \\
\hline & Nilai Severity & 8 \\
\hline & Penyebab & $\begin{array}{l}\text { Alat ukur yang sesuai tidak tersedia (misalnya } \\
\text { ampere dan volt meter) }\end{array}$ \\
\hline & Nilai Occurance & 6 \\
\hline & Pengawasan & QC Manager \\
\hline & Nilai Detection & 5 \\
\hline & $\begin{array}{l}\text { RPN sebelum } \\
\text { perbaikan }\end{array}$ & $8 \times 6 \times 5=240$ \\
\hline & $\begin{array}{l}\text { Tindakan } \\
\text { korektif/mitigasi }\end{array}$ & $\begin{array}{l}\text { 1. Pembelian alat ukur yang sesuai dan jumlah } \\
\text { yang memadai. }\end{array}$ \\
\hline & Penanggung Jawab & QC Manager \\
\hline & Tanggal Selesai & 31-Mei-2016 \\
\hline & Status Tindakan & Selesai \\
\hline & Nilai Severity & 3 \\
\hline & Nilai Occurance & 3 \\
\hline & Nilai Detection & 1 \\
\hline & $\begin{array}{l}\text { RPN setelah } \\
\text { perbaikan }\end{array}$ & $3 \times 3 \times 1=9$ \\
\hline VI & \multicolumn{2}{|l|}{ Lingkungan } \\
\hline & Mode Kegagalan & $\begin{array}{l}\text { 1. Cuaca yang ekstrim untuk pengelasan } \\
\text { (banyak hujan, angina, dan sebagainya) }\end{array}$ \\
\hline & Akibat Kegagalan & $\begin{array}{l}\text { 1. Banyak defect pengelasan berupa porosity } \\
\text { dan incomplete fusion. }\end{array}$ \\
\hline & Nilai Severity & 7 \\
\hline & Penyebab & $\begin{array}{l}\text { Pengaruh cuaca (udara) terhadap weld pool } \\
\text { sangat besar. }\end{array}$ \\
\hline & Nilai Occurance & 6 \\
\hline & Pengawasan & Welding Supervisor \\
\hline & Nilai Detection & 5 \\
\hline
\end{tabular}


IV-29

\begin{tabular}{|l|l|l|}
\hline $\begin{array}{l}\text { RPN sebelum } \\
\text { perbaikan }\end{array}$ & $\begin{array}{l}\mathbf{7} \times \mathbf{6} \times \mathbf{5}=\mathbf{2 1 0} \\
\text { Tindakan }\end{array}$ & $\begin{array}{l}\text { 1. Menggunakan workshop yang tertutup } \\
\text { (beratap) sehingga pengaruh dari luar } \\
\text { berkurang }\end{array}$ \\
\hline & Penanggung Jawab & Welding Supervisor \\
\hline & Tanggal Selesai & 31-Mei-2016 \\
\hline & Status Tindakan & Selesai \\
\hline & Nilai Severity & 3 \\
\hline & Nilai Occurance & 2 \\
\hline & Nilai Detection & 2 \\
\hline
\end{tabular}

\subsection{Mengendalikan (Control)}

Merupakan tahap analisis terakhir dari proyek Six Sigma yang menekankan kepada pendokumentasian dan penyebarluasan dari tindakan yang telah dilakukan, hal ini meliputi:

a. Melakukan pelatihan secara berkala pada supervisor dan foreman dan juga juru las/operator las dengan tingkat pemahaman dan materi yang disesuaikan dengan jabatan masing-masing.

b. Melakukan pengawasan internal baik yang dilakukan oleh departemen produksi juga oleh departemen QC atau QA sebagai pihak eksternal produksi. Ini juga bisa dalam bentuk audit-audit berkala dari pihak QA terhadap produksi.

c. Melakukan pengamatan secara terus-menerus terhadap hasil-hasil inspeksi pengelasan oleh visual dan radiografi. Mengklasifikasikan jenis-jenis cacat (defect) dan mengamati perkembangannya.

d. Membuat laporan bulanan pada manajemen puncak (top management) tentang kinerja bidang produksi pengelasan agar dapat menjadi perhatian perusahaan akan tindakan-tindakan perbaikan yang diperlukan. 
e. Menerapkan program reward dan punishment dimana pekerja dengan catatan kinerja yang baik mendapat bonus atau insentif sedangkan pekerja dengan kinerja yang rendah mendapatkan warning atau peringatan untuk memotivasi mereka agar meningkatkan kinerjanya. 


\section{BAB V \\ PENUTUP}

\subsection{Kesimpulan}

Berdasarkan data yang telah dianalisis beserta pembahasan yang telah diuraikan pada bab-bab sebelumnya, maka penulis menarik kesimpulan sebagai berikut:

1) Dengan menerapkan metode Six Sigma di Perusahaan (PT Profab Indonesia), maka Perusahaan dapat menurunkan defect rate-nya yaitu yang awalnya sebesar $15 \%$ dan setelah perbaikan menjadi 2,63\% dan meningkatkan kinerja proses dari awalnya rata-rata nilai Sigma sebesar 3,32 sekarang menjadi 4,0

2) Faktor Manusia dan Sistem Pengukuran yang diperoleh dari analisis FMEA, yang secara dominan mempengaruhi terjadinya defect dapat diatasi dan ditekan sehingga output yang dihasilkan menjadi lebih baik dan mencapai sasaran yang diinginkan.

\subsection{Saran}

Dari hasil pembahasan dan kesimpulan penelitian di atas, maka penulis memberikan beberapa saran sebagai berikut:

1) Penelitian ini dilakukan dengan metode Six Sigma dan dalam tahap improvement atau perbaikannya menggunakan metode diagram sebab-akibat, diagram pareto, konsep 5W-1H dan FMEA, sebenarnya masih banyak lagi metode-metode perbaikan lainnya yang masih dapat digunakan oleh para peneliti atau penulis lain dikemudian hari seperti FTA (Fault Tree Analysis), metode 5S, Poka Yoke, Kaizen atau metode 8D.

2) Semoga penelitian seperti ini dapat dilakukan kembali dan dikembangkan oleh generasi mahasiswa Teknik Industri STT Ibnu Sina Batam selanjutnya dan dapat bermanfaat bagi semua pihak, khususnya dalam hal analisis dan penerapan metode Six Sigma dan FMEA dalam mencari solusi perbaikanperbaikan di perusahaan-perusahaan di bidang fabrikasi ataupun bidang lainnya. 


\section{DAFTAR PUSTAKA}

Dewi, S.K. (2012, February). Minimasi Defect Produk Dengan Konsep Six Sigma. Jurnal Teknik Industri, Vol. 13, No. 1, February 2012: 43-50. Jurusan Teknik Industri. Universitas Muhammadiyah Malang. Retrieved May 15, 2016. from http://idci.dikti.go.id/pdf/JURNAL/JURNAL\%20TEKNIK\%20 INDUSTRI\%20UMM/VOL\%2013\%20No.1\%202012/662_umm_scientific_ journal.pdf.

Feigenbaum, A.V. (1986). Total Quality Control. USA. McGraw-Hill Book Co.

Gaspersz, V. (2001). ISO 9001:2000 and Continual Quality Improvement. Jakarta. PT Gramedia Pustaka Utama.

McDermott, R.E., Mikulak, R.J., \& Beuregard, M.R. (2009). The Basics of FMEA. USA. Productivity Press Group.

Montgomery, D.C. (2009). Introduction to Statistical Quality Control. USA. John Wiley \& Sons.

Muis, S. (2014). Metodologi Six Sigma. Yogyakarta. Graha Ilmu.

Pande, S.P., Neuman, R.P., \& Cavanagh, R.R. (2003). The Six Sigma Way. Yogyakarta. Andi.

Prodi Teknik Industri. (2013). Panduan Menulis Skripsi. Batam. Program Studi Teknik Industri STT Ibnu Sina.

Syukron, A. \& Kholil, M. (2013). Six Sigma-Quality for Business Improvement. Yogyakarta. Graha Ilmu.

Tjiptono, F. \& Diana, A. (2003). Total Quality Management (TQM). Yogyakarta. Andi.

Wahyuni, H.C., Sulistyowati, W., \& Khamin, M. (2015). Pengendalian Kualitas. Yogyakarta. Graha Ilmu.

Widharto, S. (2005). Inspeksi Teknik Buku 1. Jakarta. PT Pradnya Paramita.

Wahyani, W., Chobir, A., Rahmanto, A.A. Penerapan Metode Six Sigma dengan Konsep DMAIC Sebagai Alat Pengendali Kualitas. Jurusan Teknik Industri. Fakultas Teknologi Industri. Institut Teknologi Adhi Tama Surabaya (ITATS). Retrieved May 15, 2016 from http://jurnal.itats.ac.id/wpcontent/uploads/2013/06/PENERAPAN-METODE-SIX-SIGMA-DENGANKONSEP-DMAIC-SEBAGAI-ALAT-PENGENDALI-KUALITAS.pdf. 
LAMPIRAN 


\section{LAMPIRAN I}




\section{CTQ (Critical to Quality)}

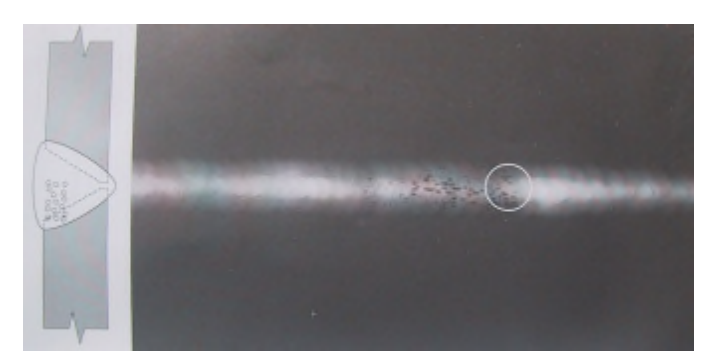

Porosity

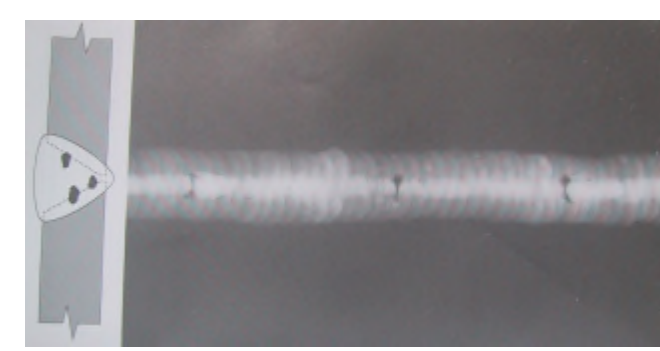

Slag Inclusion

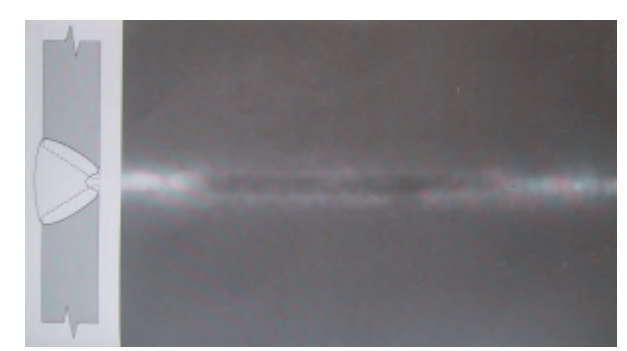

Root Concavity

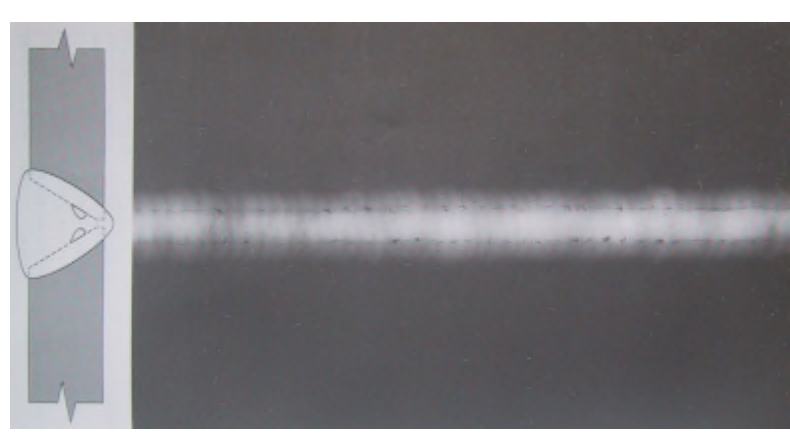

Lack of Fusion

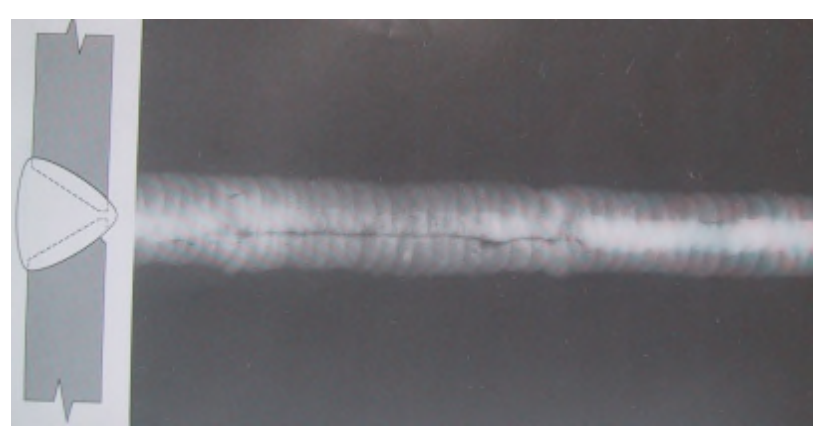

Undercut 
LAMPIRAN II 


\section{Defect Analysis Summary (Bulan Juni 2016)}

\begin{tabular}{|c|c|c|c|c|c|c|}
\hline & Minggu 1 & Minggu 2 & Minggu 3 & Minggu 4 & TOTAL & Drocontaco \\
\hline $\begin{array}{c}\text { Jenis Defect } \\
\text { (Opportunities) }\end{array}$ & Jumlah defect & Jumlah defect & Jumlah defect & Jumlah defect & Jumlah defect & $\begin{array}{c}\text { Defect } \\
\text { Defe }\end{array}$ \\
\hline Lack of Fusion & 2 & 2 & 1 & 2 & 7 & $1.16 \%$ \\
\hline Porosity & 2 & 2 & 2 & 1 & 7 & $1.16 \%$ \\
\hline Slag Inclusion & 3 & 1 & 2 & 1 & 7 & $1.16 \%$ \\
\hline Undercut & 1 & 1 & 2 & 1 & 5 & $0.83 \%$ \\
\hline \multirow[t]{2}{*}{ Root Concavity } & 0 & 0 & 0 & 0 & 0 & $0.00 \%$ \\
\hline & 8 & 6 & 7 & 5 & 26 & 0 \\
\hline
\end{tabular}

\begin{tabular}{|l|c|c|c|c|c|}
\cline { 2 - 6 } \multicolumn{1}{c|}{} & Lack of Fusion & Porosity & Slag Inciusion & Undercut & Root Concavity \\
\hline Defect & 7 & 7 & 7 & 5 & $0.00 \%$ \\
\hline Total defect & 26 & 26 & 26 & 26 & 26 \\
\hline Prosentase & $\mathbf{2 6 . 9 2 \%}$ & $\mathbf{2 6 . 9 2 \%}$ & $\mathbf{2 6 . 9 2 \%}$ & $\mathbf{1 9 . 2 3 \%}$ & $\mathbf{0 . 0 0 \%}$ \\
\hline
\end{tabular}

\begin{tabular}{|c|c|c|c|c|c|}
\hline Deskripsi & Minggu 1 & Minggu 2 & Minggu 3 & Minggu 4 & \\
\hline Film yang diinspeksi & 221 & 245 & 265 & 256 & 987 \\
\hline Defect & 8 & 6 & 7 & 5 & 26 \\
\hline Prosentase & $3.62 \%$ & $2.45 \%$ & $2.64 \%$ & $1.95 \%$ & $2.63 \%$ \\
\hline DPU & $0.72 \%$ & $0.49 \%$ & $0.53 \%$ & $0.39 \%$ & $0.53 \%$ \\
\hline Yield & $99.28 \%$ & $99.51 \%$ & $99.47 \%$ & $99.61 \%$ & $99.47 \%$ \\
\hline DPMO & 7239.82 & 4897.96 & 5283.02 & 3906.25 & 5268.49 \\
\hline Sigma Level & 4.05 & 4.15 & 4.15 & 4.15 & 4.10 \\
\hline
\end{tabular}


LAMPIRAN III 


\section{FMEA (Failure Mode \& Effects Analysis) Systems}

\section{Kriteria Severity (S)}

\begin{tabular}{|c|c|c|}
\hline Nilai & Deskripsi & Kriteria \\
\hline $1-2$ & Tidak penting & Tidak mempengaruhi proses \\
\hline $3-4$ & Cukup Penting & Sedikit berpengaruh pada kinerja \\
\hline $5-6$ & Penting & Mengurangi kinerja dan dapat menurunkan kualitas \\
\hline $7-9$ & Kritis & Kinerja sangat buruk \\
\hline 10 & Bahaya & Tidak dapat diterima \\
\hline
\end{tabular}

\section{Kriteria Occurence (0)}

\begin{tabular}{|c|c|c|}
\hline Nilai & Deskripsi & Kriteria \\
\hline $1-2$ & Jarang & Belum terjadi kegagalan, namun dapat saja terjadi \\
\hline $3-4$ & Kadang-kadang & Satu atau dua kali kegagalan terjadi \\
\hline $5-6$ & Cukup sering & Mulai terjadi beberapa kali \\
\hline $7-9$ & Sering & Kejadian mulai sering berulang \\
\hline 10 & Sangat sering & Kejadian sering terjadi/berulang \\
\hline
\end{tabular}

\section{Kriteria Detection (D)}

\begin{tabular}{|c|c|c|}
\hline Nilai & Deskripsi & Kriteria \\
\hline $1-2$ & Sangat Baik & Mudah diketahui \\
\hline $3-4$ & Baik & Dapat diketahui dengan pengawasan \\
\hline $5-6$ & Cukup & Diketahui dengan pengawasan dan verifikasi \\
\hline $7-9$ & Tidak Baik & Sulit untuk diketahui \\
\hline 10 & Sangat tidak baik & Hampir tidak dapat diketahui \\
\hline
\end{tabular}

\footnotetext{
FORMULA : RPN $=S \times O \times D$
}

\section{RPN = RISK PRIORITY NUMBER}

\begin{tabular}{|c|c|}
\hline Nilai & Deskripsi \\
\hline$<27$ & Rendah \\
\hline $27-216$ & Sedang \\
\hline$>216-512$ & Tinggi \\
\hline$>512-1000$ & Sangat Tinggi \\
\hline
\end{tabular}




\section{PROFAB}

FMEA (Failure Mode \& Effects Analysis)

Prepared by: Decky Antoni (QA Manager)

Department : Produksi (Pengelasan)

Document No: PFB/FMEA/16/001 Rev 0

Tanggal : 07-Jun-16

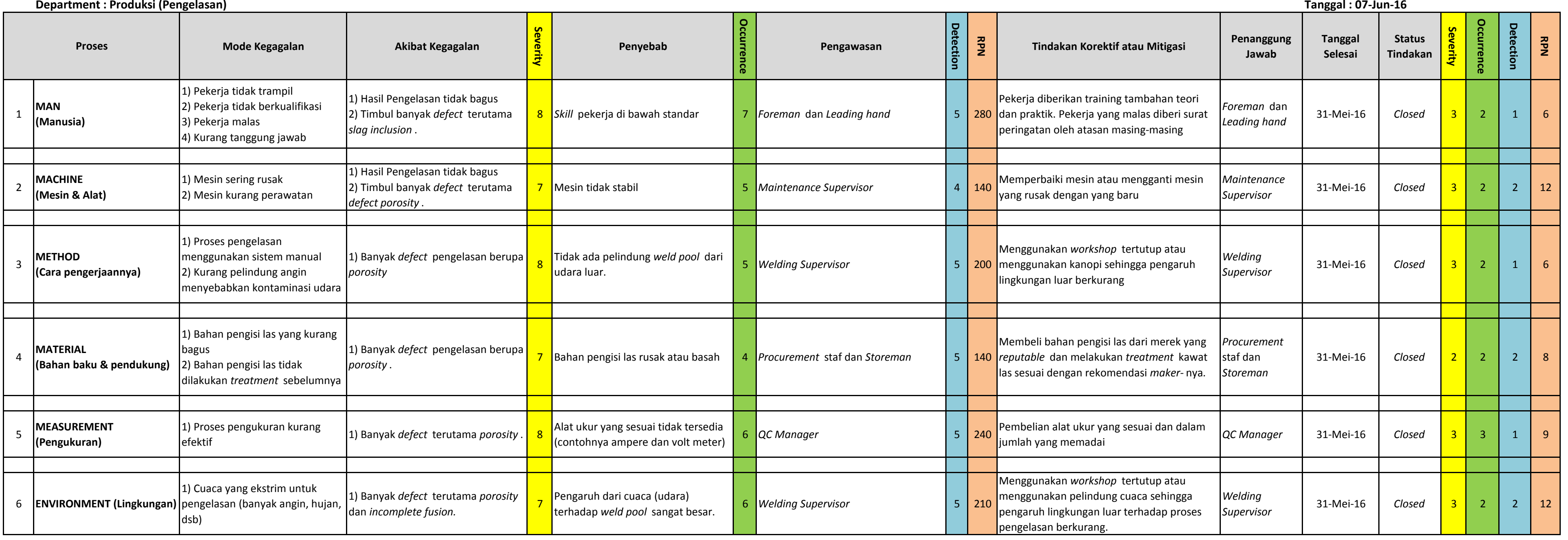




\section{LAMPIRAN IV}


NeY PROFAB
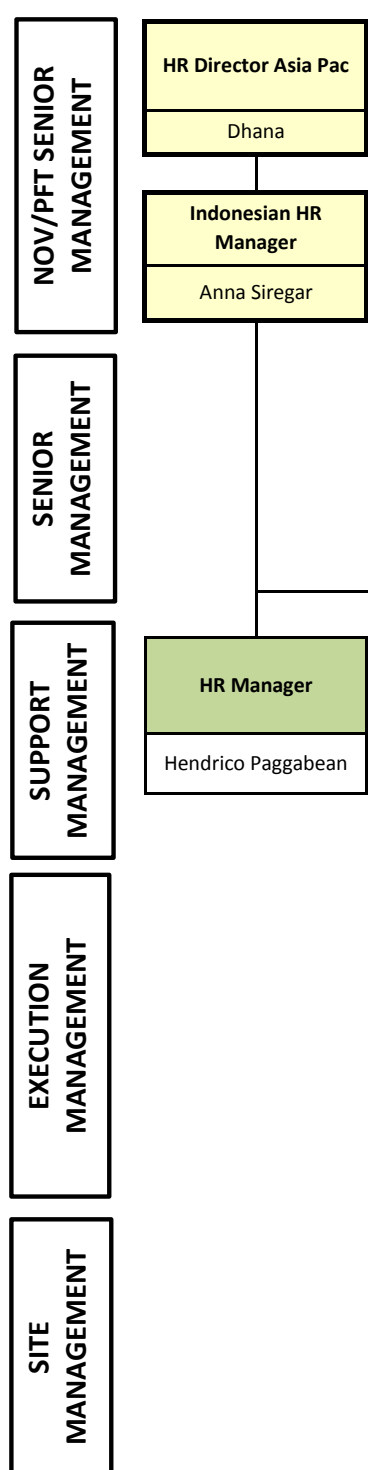

-
Organisation Chart
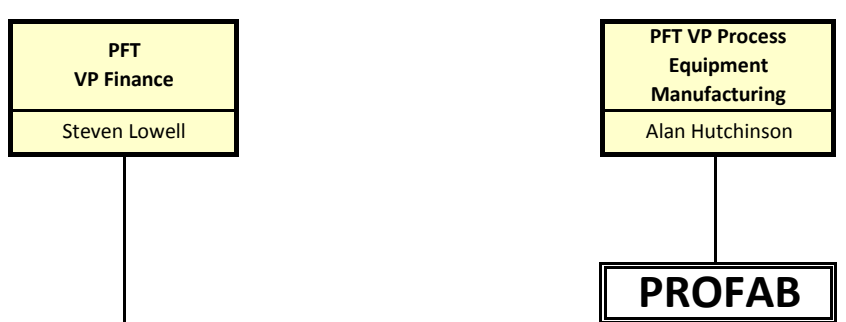

i
PROFAB
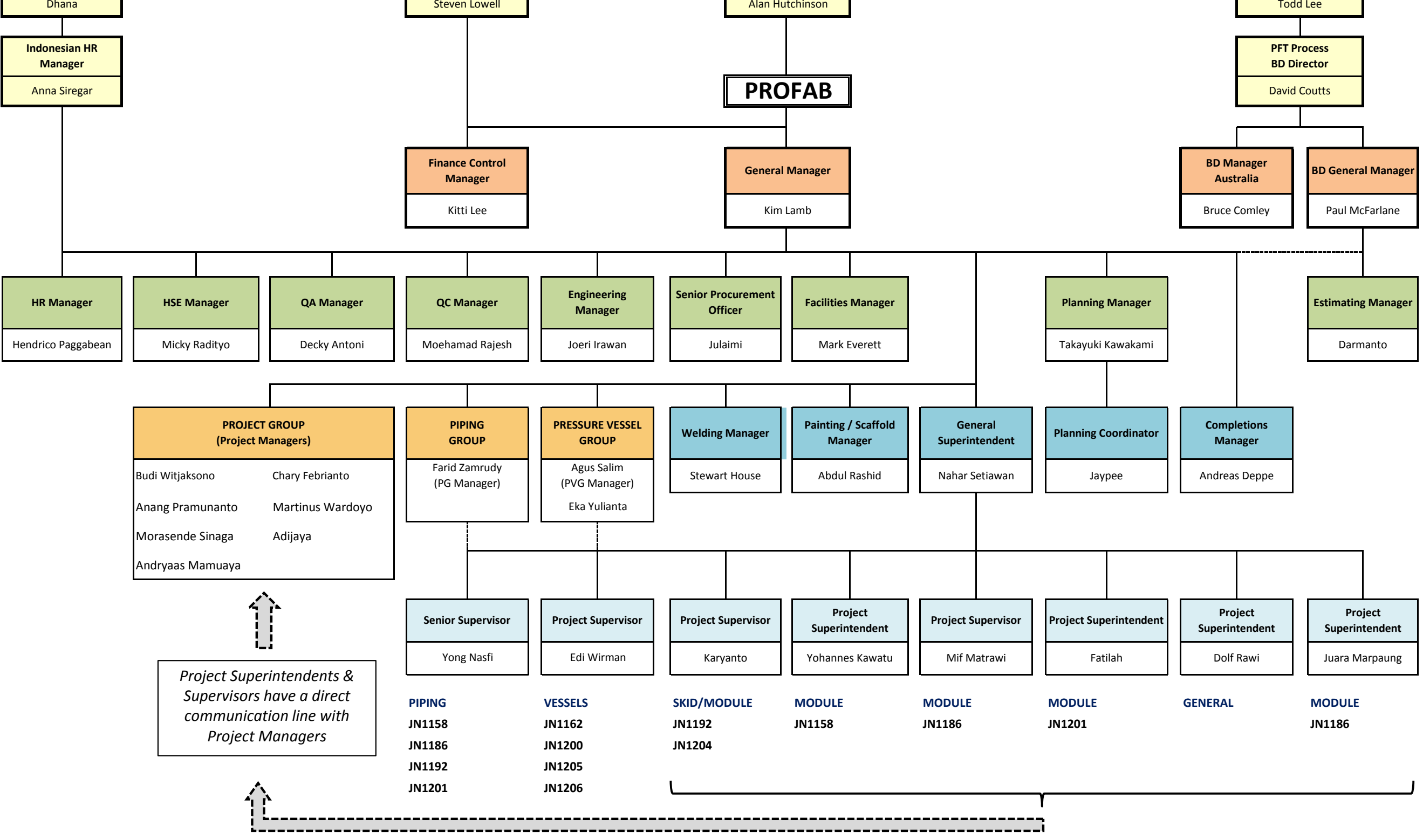

Updated: 15 June 2016

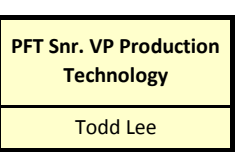

PFT Process

PFT Process
BD Director

David Coutts 
LAMPIRAN V 


\section{PZOFA3}

\section{PRODUCTION FLOW CHART (PRESSURE EQUIPMENT AND PIPING)}

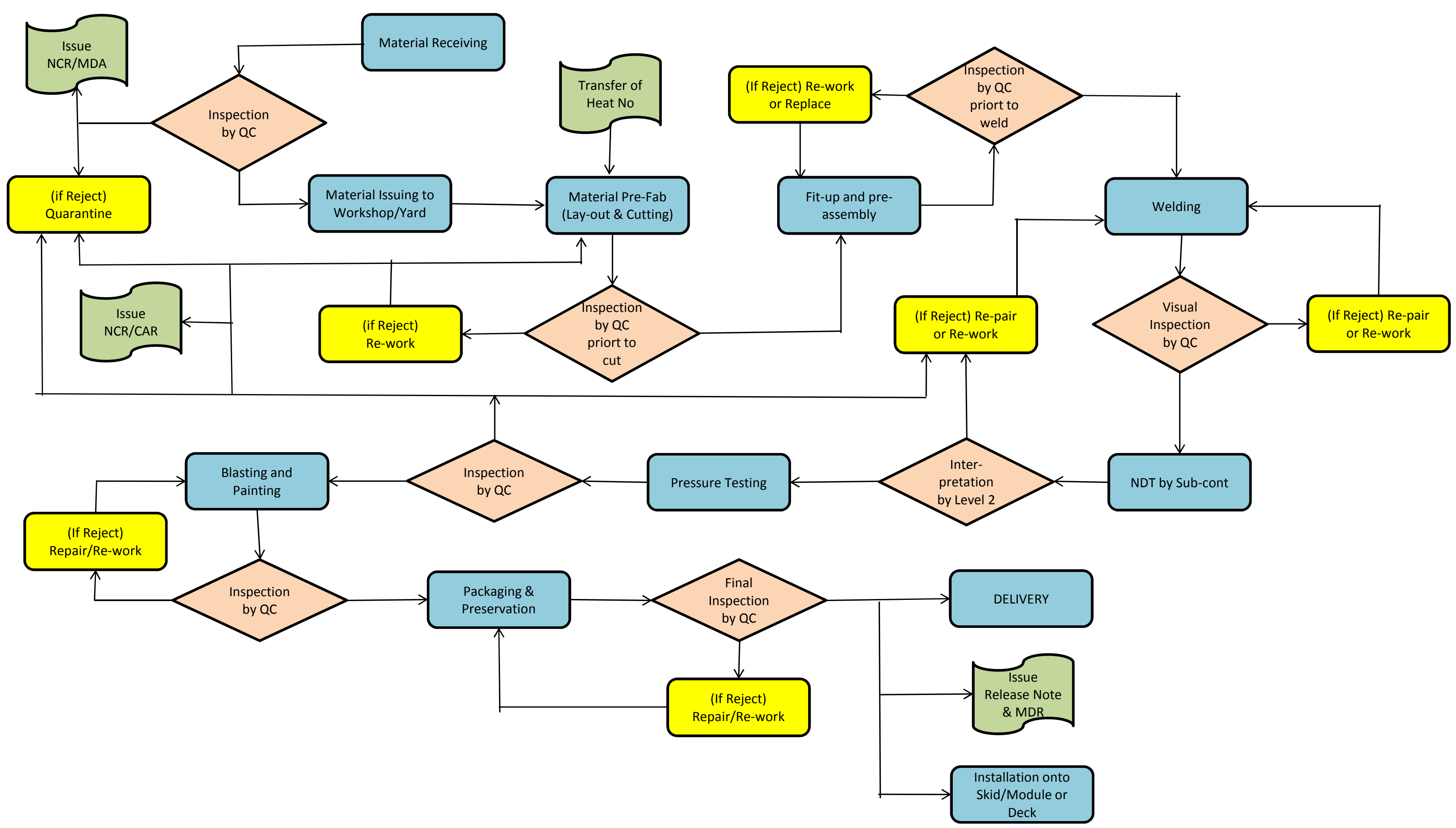




\section{LAMPIRAN VI}




\section{Project Portfolio}

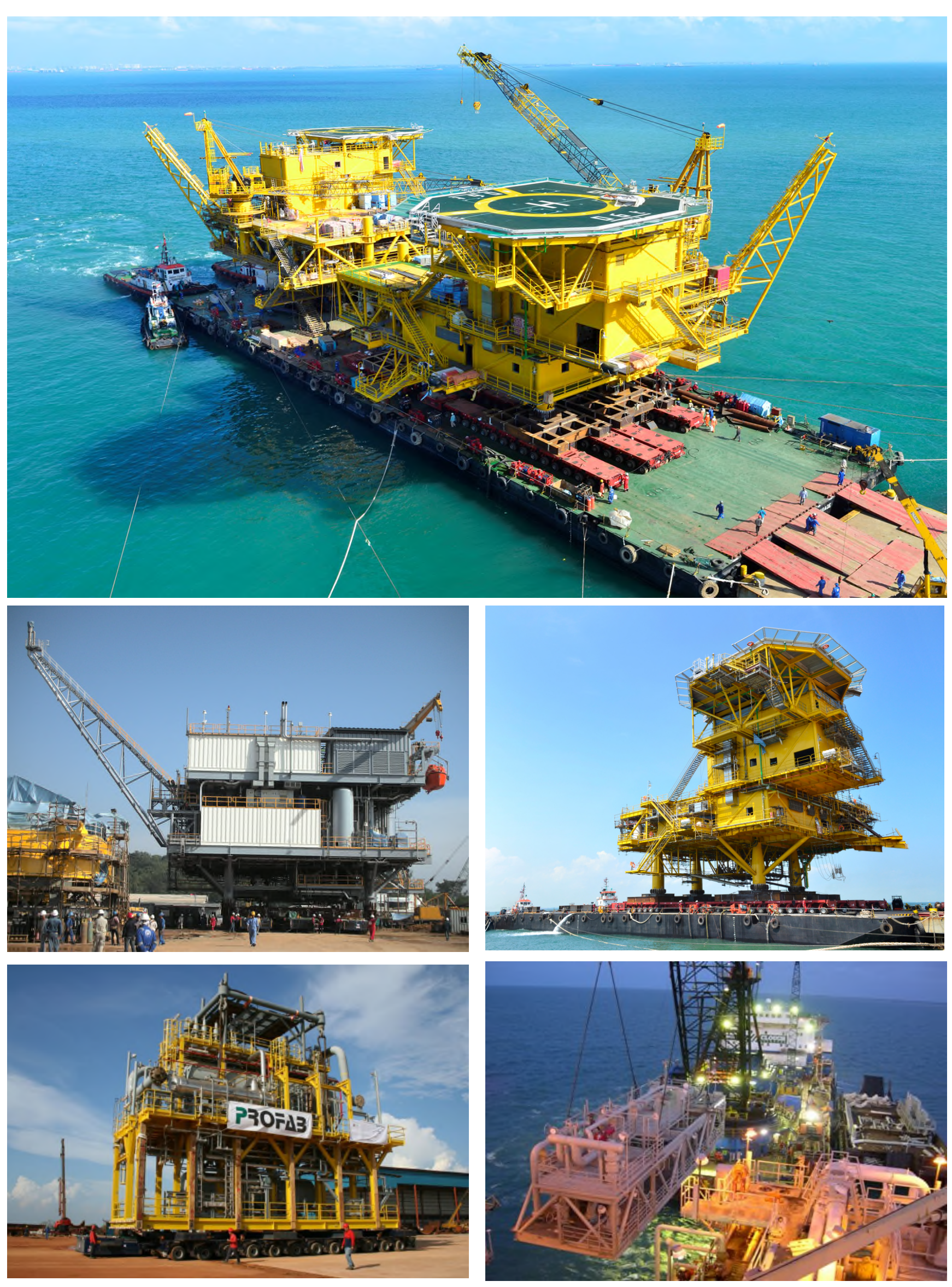



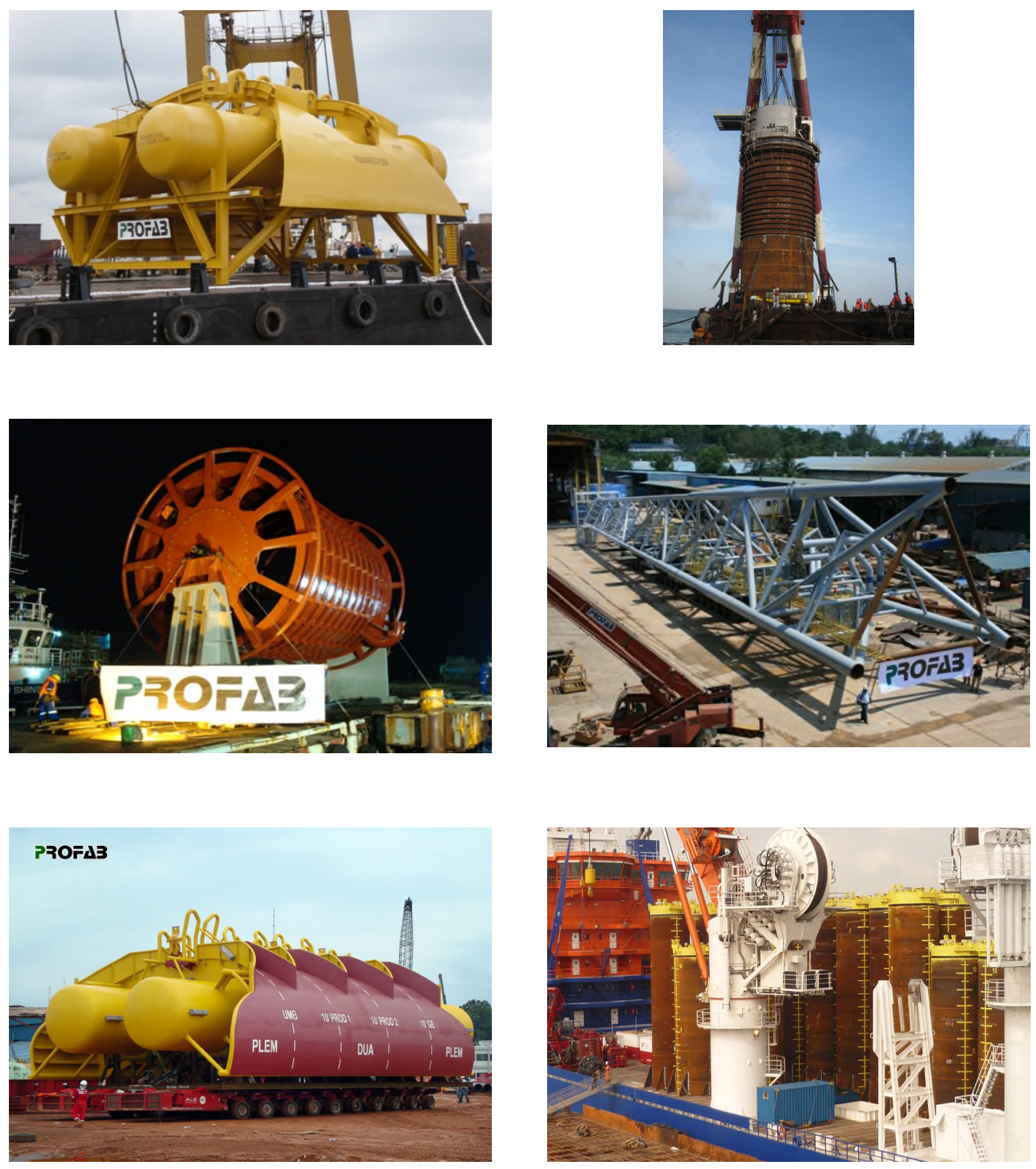

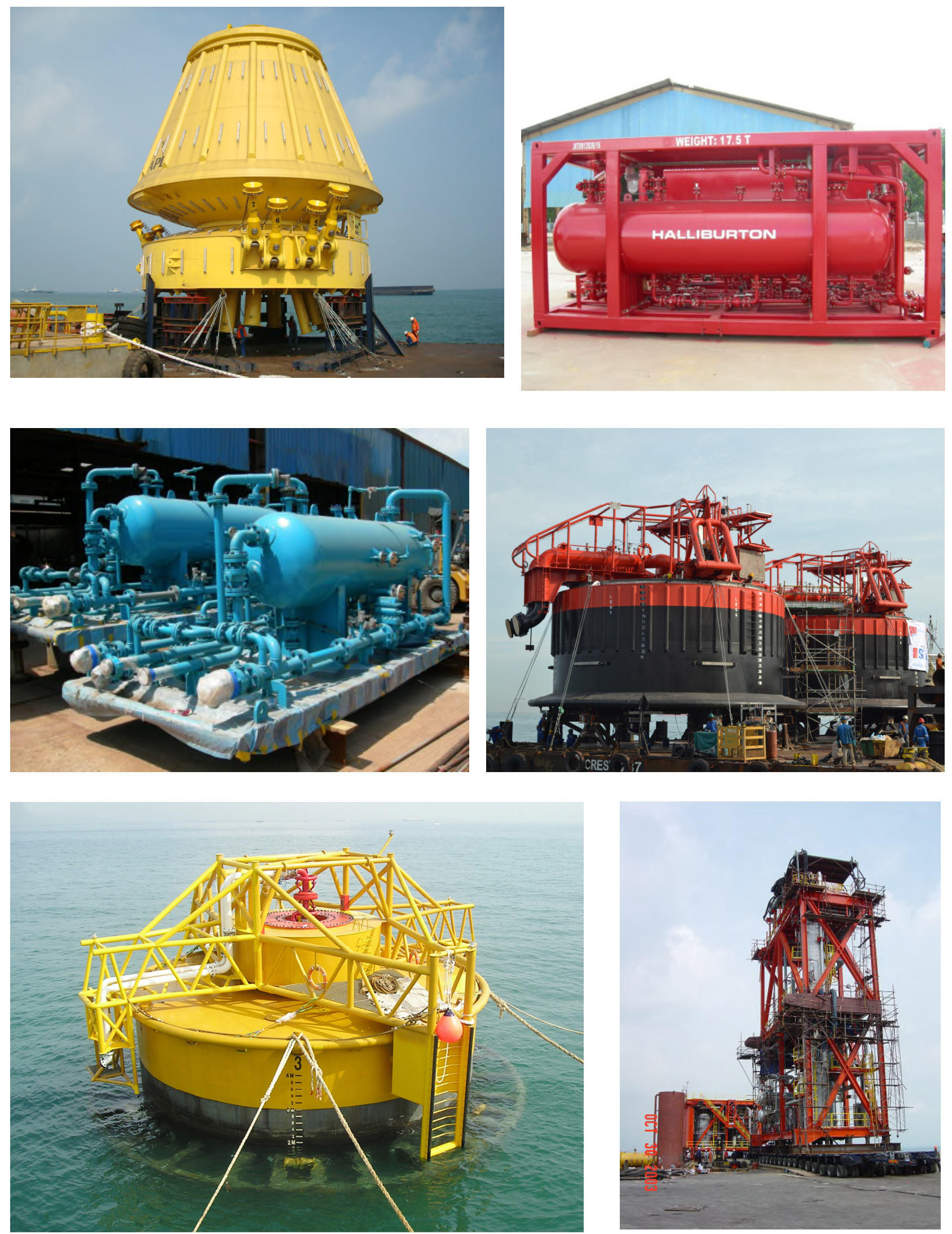


\section{Project Portfolio}

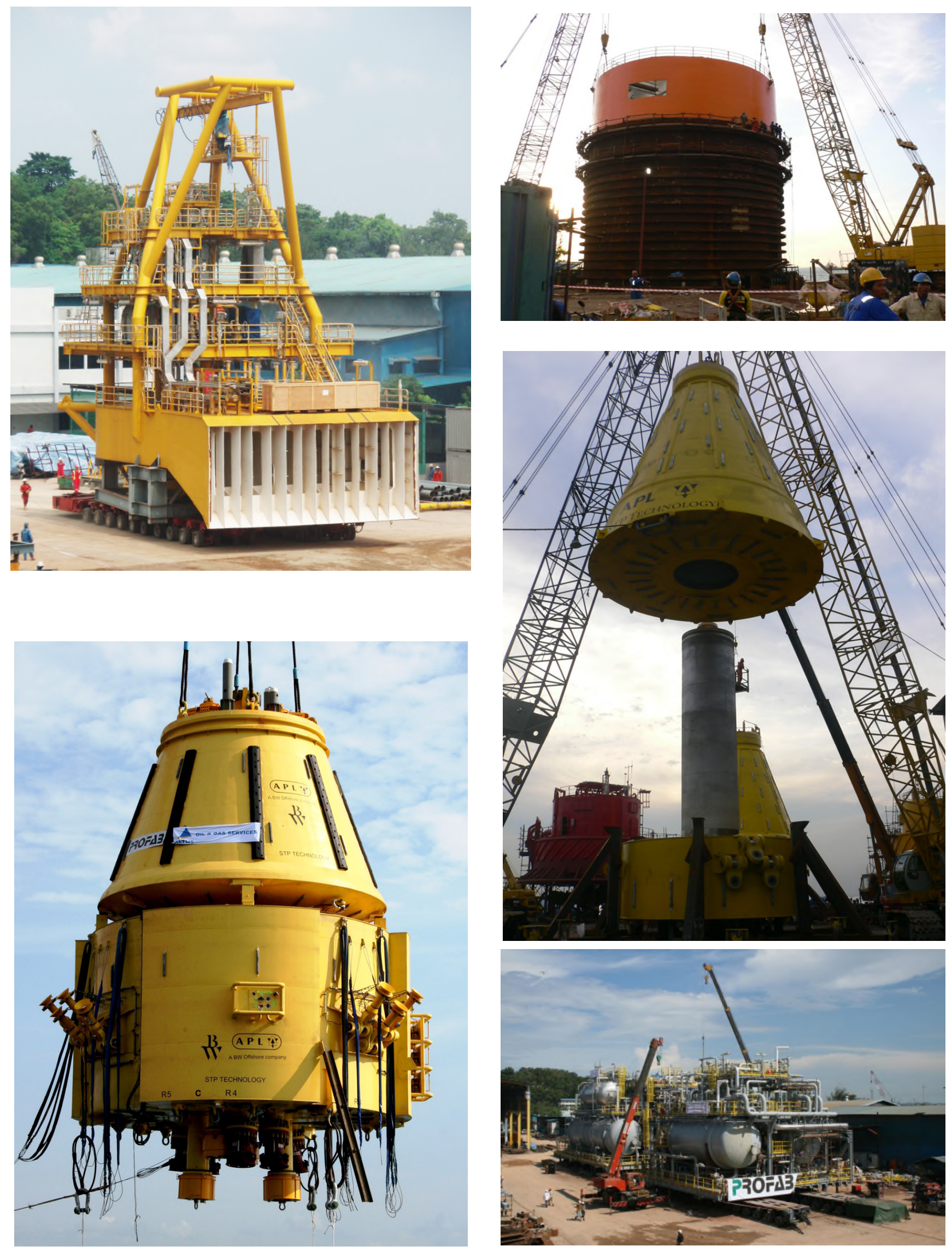




\section{Production Solutions}
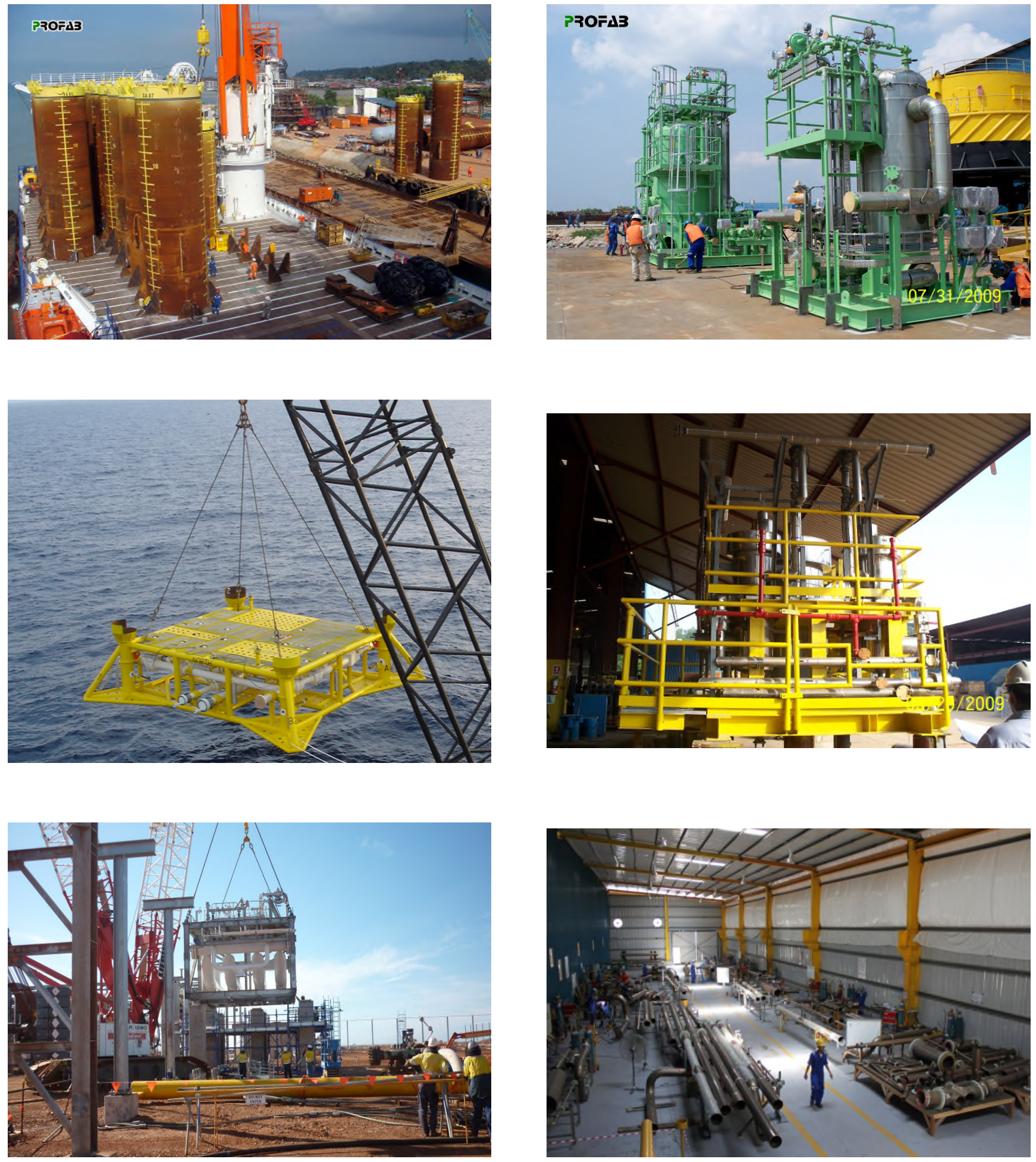


\section{Production Solutions}
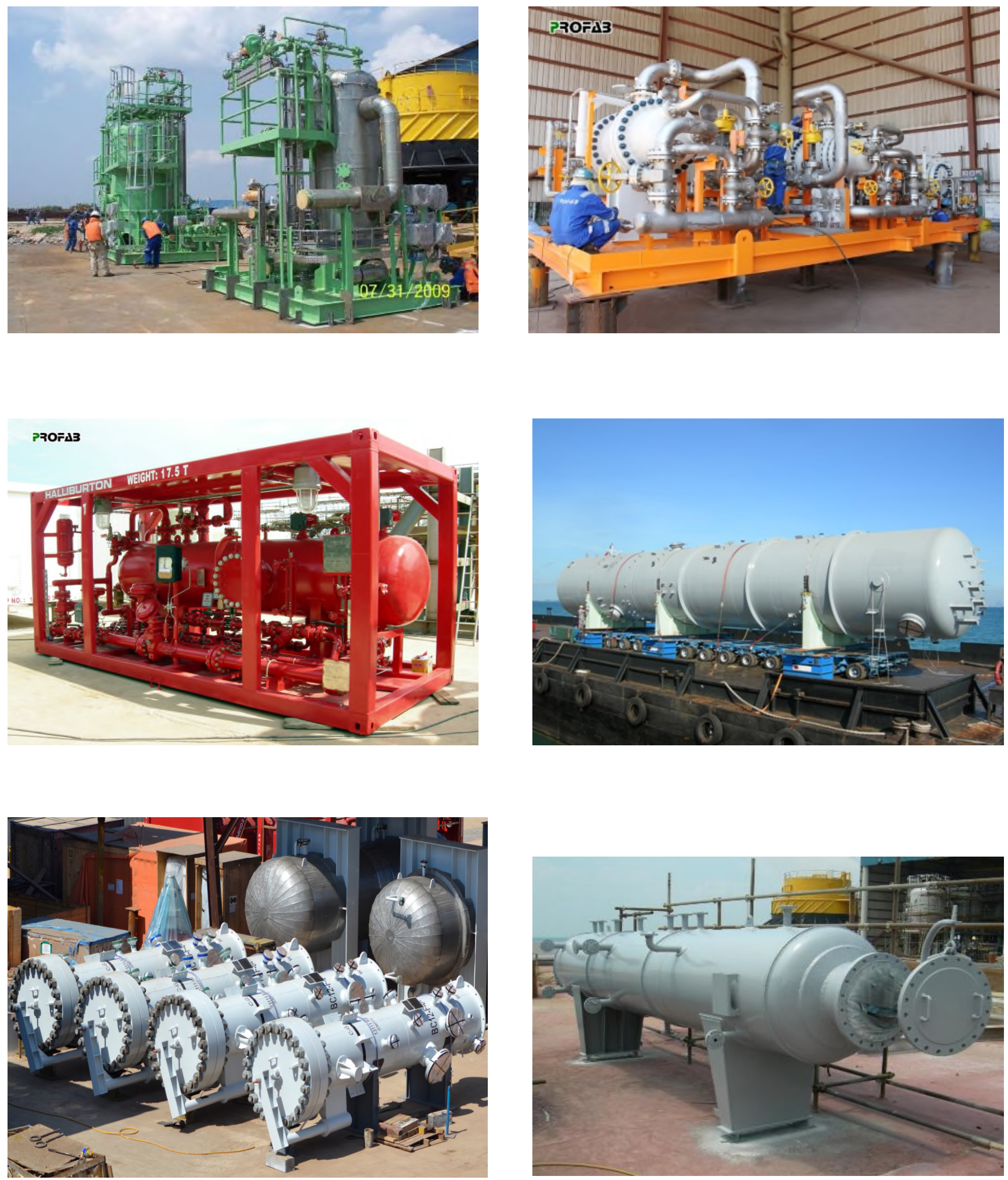
LAMPIRAN VII 


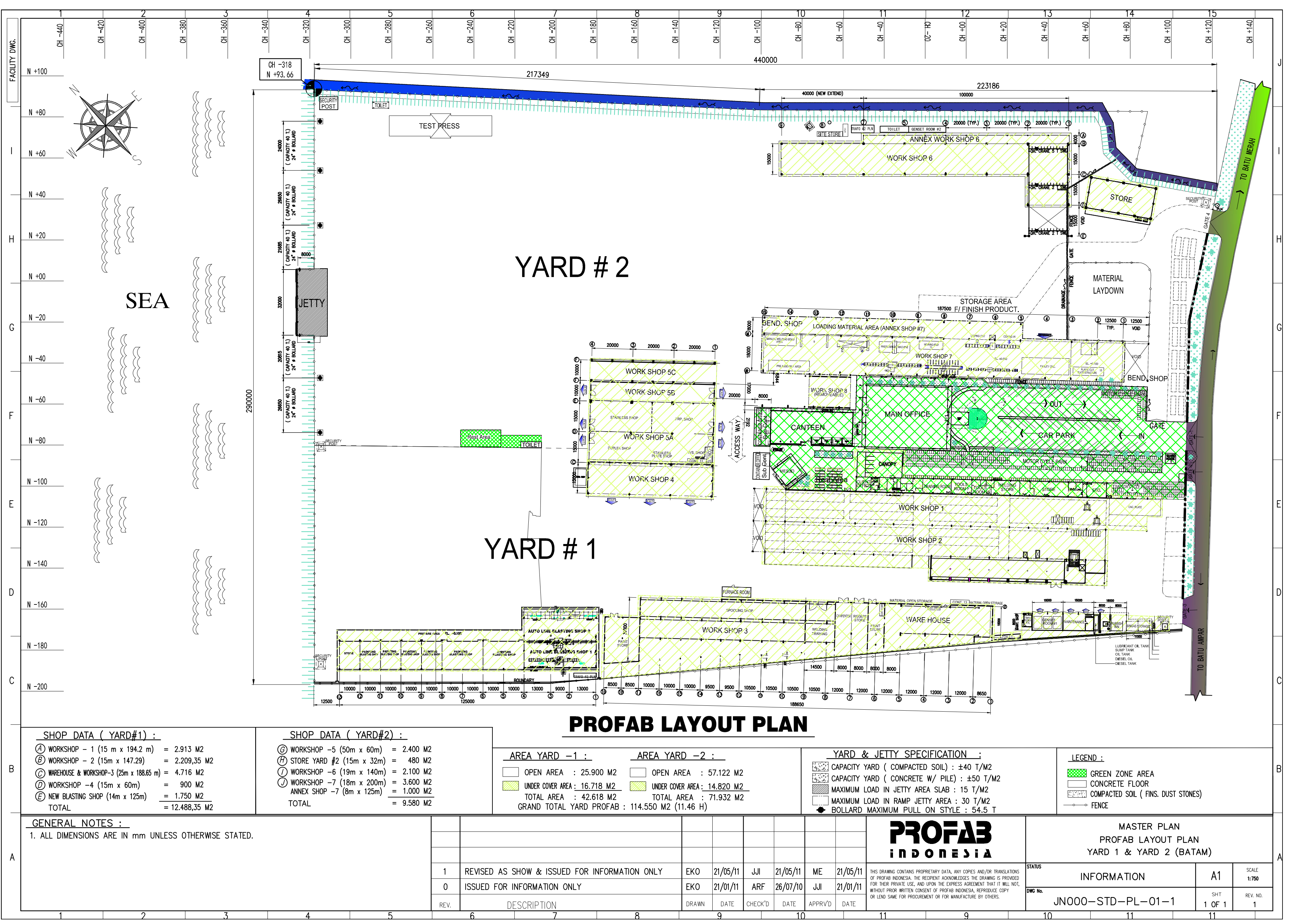


LAMPIRAN VIII 
PROJECT ON TIME DELIVERY LIST (2015)

\begin{tabular}{|c|c|c|c|c|c|}
\hline No & Job No & Client & Project & Product & Delivery \\
\hline 1 & 1165 & NATIONAL OILWELL VARCO & CATCHER FPSO & BUOY \& TURRET & On time \\
\hline 2 & 1166 & BERTLING PTE LTD & LOAD OUT CHILLER SKID & LOAD OUT CHILLER SKID & late \\
\hline 3 & 1167 & NATIONAL OILWELL VARCO & CATCHER FPSO & SWIVEL SUPPORT STRUCTURE & On time \\
\hline 4 & 1168 & NATIONAL OILWELL VARCO & BUOY \& TURRET FOR RUBICON & OFFLOADING \& REFURBISHMENT PHASE 1 & On time \\
\hline 5 & 1169 & NATIONAL OILWELL VARCO & - & SUPPLY AND FABRICATION OF HIGH PRESSURE TEST CELL & On time \\
\hline 6 & 1170 & PROCESS GROUP PTE LTD & GAS DEHYDRATION SKID & 1 UNIT SKID PACKAGE & On time \\
\hline 7 & 1171 & NATIONAL OILWELL VARCO & GINA KROG & SUPPLY AND FABRICATION OF ANCHOR PILES & late \\
\hline 8 & 1172 & NATIONAL OILWELL VARCO & CATCHER PROJECT & SUPPLY AND FABRICATION OF ANCHOR PILES & On time \\
\hline 9 & 1173 & OFFSHORE CONSTRUCTION SPECIALIST & R1867 CROWLEY & - & On time \\
\hline 10 & 1174 & ODS METERING SYSTEM & CATCHER PROJECT & SUPPLY AND FABRICATION OF METERING SKID & late \\
\hline 11 & 1175 & ODS METERING SYSTEM & BUMI ARMADA PROJECT & SUPPLY AND FABRICATION OF METERING SKID & On time \\
\hline 12 & 1176 & KAWASAKI HEAVY INDUSTRIES & ICHTHYS ONSHORE LNG FACILITIES PROJECT & $\begin{array}{l}\text { FABRICATION OF SUPPORT FRAME AND ROOF MAIN PLATFORM } \\
\text { MODULARIZATION FOR LPG TANKS }\end{array}$ & On time \\
\hline 13 & 1177 & TEEKAY PETROJARL PRODUCTION AL & KNARR FPSO PROJECT & PROVISION DOCUMENTATION FOR DPS PROJECT & On time \\
\hline 14 & 1178 & NATIONAL OILWELL VARCO & GINA KROGH & FABRICATION OF MATING CONE SEAL PLUG & On time \\
\hline 15 & 1179 & NATIONAL OILWELL VARCO & PUFIN FPSO PROJECT & SUPPLY AND FABRICATION OF CRADDLE SUPPORT & On time \\
\hline 16 & 1180 & PROCESS GROUP SINGAPORE & EXXONMOBILE-SAKHALIN ISLAND & SUPPLY AND FABRICATION OF CLAD VESSELS & late \\
\hline 17 & 1181 & PROCESS GROUP SINGAPORE & EXXONMOBILE-SAKHALIN ISLAND & SUPPLY AND FABRICATION OF 6 x CS VESSELS & late \\
\hline 18 & 1182 & NATIONAL OILWELL VARCO & 1908 GINA KROGH & SUPPLY AND FABRICATION OF DOWN PULL SHEAVE & On time \\
\hline 19 & 1183 & NATIONAL OILWELL VARCO & TAIYUAN TZ-400 PROJECT & SUPPLY AND FABRICATION OF SUPPORT SKID & On time \\
\hline 20 & 1184 & CLADTEK & CT251-BEND TEST & CUT AND ROLLING PLATE & On time \\
\hline 21 & 1185 & ALDERLY & INPEX-ICHTYS & SUPPLY AND FABRICATION OF CLOSED DRAIN LINE AND MISC. & On time \\
\hline 22 & 1186 & SIEMENS & YINSON & FABRICATION OF SEA WATER TREATMENT & On time \\
\hline
\end{tabular}


PROJECT ON TIME DELIVERY LIST (2015)

On Time Delivery Chart (2015)

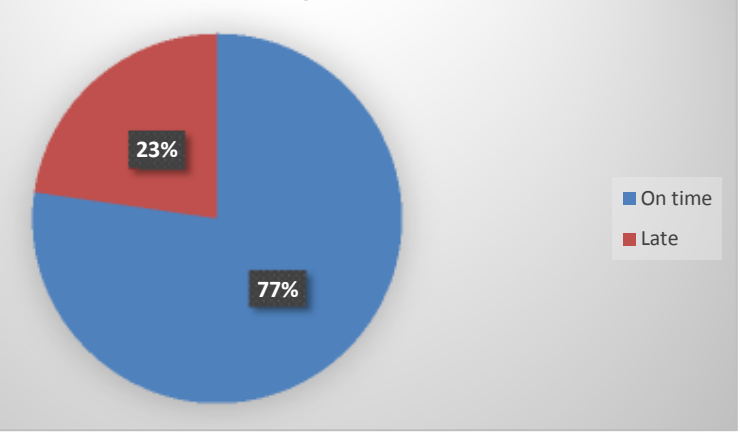


PROJECT ON TIME DELIVERY LIST (UP TO JUNE 2016)

\begin{tabular}{|c|c|c|c|c|c|}
\hline No & Job No & Client & Project & Product & Delivery \\
\hline 1 & 1187 & BUMI ARMADA & HUSKY - MADURA BD FIELD PROJECT & SUPPLY AND FABRICATION OF MOORING PILES & On time \\
\hline 2 & 1188 & $\begin{array}{l}\text { REFRIGERANT ENGINEERING INTERNATIONAL } \\
\text { PTY LTD }\end{array}$ & QCLNG-UPSTREAM PHASE II- TRANCHE 1B & SUPPLY AND FABRICATION OF PRESSURE VESSEL & On time \\
\hline 3 & 1190 & DSME Co. Ltd. Korea & WHEATSTONE PROJECT & SUPPLY GASKET & On time \\
\hline 4 & 1182 & NATIONAL OILWELL VARCO & 1908 GINA KROGH & SUPPLY AND FABRICATION OF DOWN PULL SHEAVE & On time \\
\hline 5 & 1183 & NATIONAL OILWELL VARCO & TAIYUAN TZ-400 PROJECT & SUPPLY AND FABRICATION OF SUPPORT SKID & On time \\
\hline 7 & 1185 & ALDERLY & INPEX-ICHTYS & SUPPLY AND FABRICATION OF CLOSED DRAIN LINE AND MISC. & On time \\
\hline 8 & 1186 & SIEMENS & YINSON & FABRICATION OF SEA WATER TREATMENT & On time \\
\hline 9 & 1187 & BUMI ARMADA & HUSKY - MADURA BD FIELD PROJECT & SUPPLY AND FABRICATION OF MOORING PILES & On time \\
\hline 10 & 1188 & $\begin{array}{l}\text { REFRIGERANT ENGINEERING INTERNATIONAL } \\
\text { PTY LTD }\end{array}$ & QCLNG-UPSTREAM PHASE II- TRANCHE $1 \mathrm{~B}$ & SUPPLY AND FABRICATION OF PRESSURE VESSEL & On time \\
\hline 11 & 1190 & DSME Co. Ltd. Korea & WHEATSTONE PROJECT & SUPPLY GASKET & On time \\
\hline
\end{tabular}

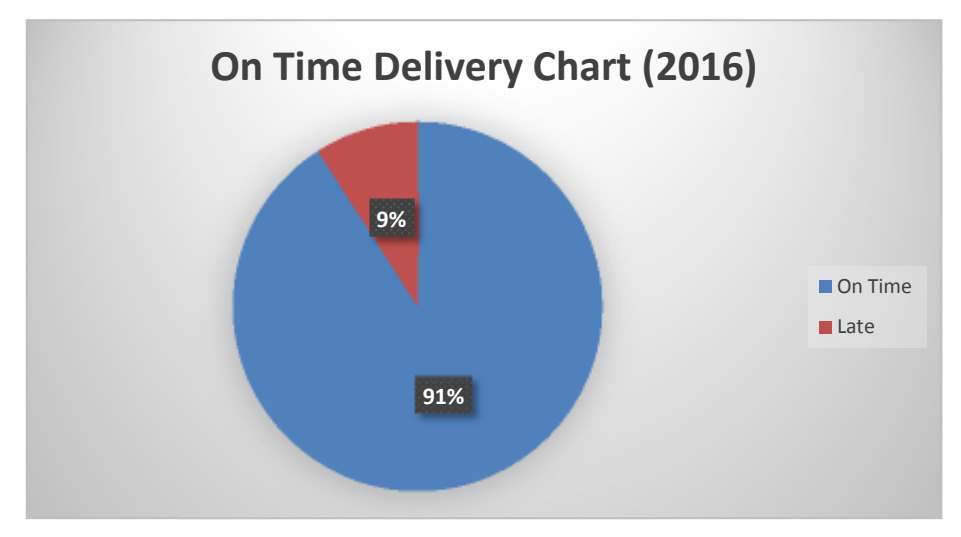




\section{LAMPIRAN IX}


Konversi DPMO ke Nilai Sigma Berdasarkan Konsep Motorola

\begin{tabular}{|c|c|c|c|c|c|c|c|}
\hline $\begin{array}{l}\text { Nilai } \\
\text { Sigma }\end{array}$ & DPMO & $\begin{array}{l}\text { Nilai } \\
\text { Sigma }\end{array}$ & DPMO & $\begin{array}{l}\text { Nilai } \\
\text { Sigma }\end{array}$ & DPMO & $\begin{array}{l}\text { Nilai } \\
\text { Sigma }\end{array}$ & DPMO \\
\hline 0,00 & 933.193 & 0,51 & 838.913 & 1,02 & 684.386 & 1,53 & 488.033 \\
\hline 0,01 & 931.888 & 0,52 & 836.457 & 1,03 & 680.822 & 1,54 & 484.047 \\
\hline 0,02 & 930.563 & 0,53 & 833.977 & 1,04 & 677.242 & 1,55 & 480.061 \\
\hline 0,03 & 929.219 & 0,54 & 831.472 & 1,05 & 673.645 & 1,56 & 476.078 \\
\hline 0,04 & 927.855 & 0,55 & 828.944 & 1,06 & 670.031 & 1,57 & 472.097 \\
\hline 0,05 & 926.471 & 0,56 & 826.391 & 1,07 & 666.402 & 1,58 & 468.119 \\
\hline 0,06 & 925.066 & 0,57 & 823.814 & 1,08 & 662.757 & 1,59 & 464.144 \\
\hline 0,07 & 923.641 & 0,58 & 821.214 & 1,09 & 659.097 & 1,60 & 460.172 \\
\hline 0,08 & 922.196 & 0,59 & 818.589 & 1,10 & 655.422 & 1,61 & 456.205 \\
\hline 0,09 & 920.730 & 0,60 & 815.940 & 1,11 & 651.732 & 1,62 & 452.242 \\
\hline 0,10 & 919.243 & 0,61 & 813.267 & 1,12 & 648.027 & 1,63 & 448.283 \\
\hline 0,11 & 917.736 & 0,62 & 810.570 & 1,13 & 644.309 & 1,64 & 444.330 \\
\hline 0,12 & 916.207 & 0,63 & 807.850 & 1,14 & 640.576 & 1,65 & 440.382 \\
\hline 0,13 & 914.656 & 0,64 & 805.106 & 1,15 & 636.831 & 1,66 & 436.441 \\
\hline 0,14 & 913.085 & 0,65 & 802.338 & 1,16 & 633.072 & 1,67 & 432.505 \\
\hline 0,15 & 911.492 & 0,66 & 799.546 & 1,17 & 629.300 & 1,68 & 428.576 \\
\hline 0,16 & 909.877 & 0,67 & 796.731 & 1,18 & 625.516 & 1,69 & 424.655 \\
\hline 0,17 & 908.241 & 0,68 & 793.892 & 1,19 & 621.719 & 1,70 & 420.740 \\
\hline 0,18 & 906.582 & 0,69 & 791.030 & 1,20 & 617.911 & 1,71 & 416.834 \\
\hline 0,19 & 904.902 & 0,70 & 788.145 & 1,21 & 614.092 & 1,72 & 412.936 \\
\hline 0,20 & 903.199 & 0,71 & 785.236 & 1,22 & 610.261 & 1,73 & 409.046 \\
\hline 0,21 & 901.475 & 0,72 & 782.305 & 1,23 & 606.420 & 1,74 & 405.165 \\
\hline 0,22 & 899.727 & 0,73 & 779.350 & 1,24 & 602.568 & 1,75 & 401.294 \\
\hline 0,23 & 897.958 & 0,74 & 776.373 & 1,25 & 598.706 & 1,76 & 397.432 \\
\hline 0,24 & 896.165 & 0,75 & 773.373 & 1,26 & 594.835 & 1,77 & 393.580 \\
\hline 0,25 & 894.350 & 0,76 & 770.350 & 1,27 & 590.954 & 1,78 & 389.739 \\
\hline 0,26 & 892.512 & 0,77 & 767.305 & 1,28 & 587.064 & 1,79 & 385.908 \\
\hline 0,27 & 890.651 & 0,78 & 764.238 & 1,29 & 583.166 & 1,80 & 382.089 \\
\hline 0,28 & 888.767 & 0,79 & 761.148 & 1,30 & 579.260 & 1,81 & 378.281 \\
\hline 0,29 & 886.860 & 0,80 & 758.036 & 1,31 & 575.345 & 1,82 & 374.484 \\
\hline 0,30 & 884.930 & 0,81 & 754.903 & 1,32 & 571.424 & 1,83 & 370.700 \\
\hline 0,31 & 882.977 & 0,82 & 751.748 & 1,33 & 567.495 & 1,84 & 366.928 \\
\hline 0,32 & 881.000 & 0,83 & 748.571 & 1,34 & 563.559 & 1,85 & 363.169 \\
\hline 0,33 & 878.999 & 0,84 & 745.373 & 1,35 & 559.618 & 1,86 & 359.424 \\
\hline 0,34 & 876.976 & 0,85 & 742.154 & 1,36 & 555.670 & 1,87 & 355.691 \\
\hline 0,35 & 874.928 & 0,86 & 738.914 & 1,37 & 551.717 & 1,88 & 351.973 \\
\hline 0,36 & 872.857 & 0,87 & 735.653 & 1,38 & 547.758 & 1,89 & 348.268 \\
\hline 0,37 & 870.762 & 0,88 & 732.371 & 1,39 & 543.795 & 1,90 & 344.578 \\
\hline 0,38 & 868.643 & 0,89 & 729.069 & 1,40 & 539.828 & 1,91 & 340.903 \\
\hline 0,39 & 866.500 & 0,90 & 725.747 & 1,41 & 535.856 & 1,92 & 337.243 \\
\hline 0,40 & 864.334 & 0,91 & 722.405 & 1,42 & 531.881 & 1,93 & 333.598 \\
\hline 0,41 & 862.143 & 0,92 & 719.043 & 1,43 & 527.903 & 1,94 & 329.969 \\
\hline 0,42 & 859.929 & 0,93 & 715.661 & 1,44 & 523.922 & 1,95 & 326.355 \\
\hline 0,43 & 857.690 & 0,94 & 712.260 & 1,45 & 519.939 & 1,96 & 322.758 \\
\hline
\end{tabular}


Konversi DPMO ke Nilai Sigma Berdasarkan Konsep Motorola

\begin{tabular}{|c|c|c|c|c|c|c|c|}
\hline $\begin{array}{c}\text { Nilai } \\
\text { Sigma }\end{array}$ & DPMO & $\begin{array}{c}\text { Nilai } \\
\text { Sigma }\end{array}$ & DPMO & $\begin{array}{c}\text { Nilai } \\
\text { Sigma }\end{array}$ & DPMO & $\begin{array}{c}\text { Nilai } \\
\text { Sigma }\end{array}$ & DPMO \\
\hline 0,44 & 855.428 & 0,95 & 708.840 & 1,46 & 515.953 & 1,97 & 319.178 \\
0,45 & 853.141 & 0,96 & 705.402 & 1,47 & 511.967 & 1,98 & 315.614 \\
0,46 & 850.830 & 0,97 & 701.944 & 1,48 & 507.978 & 1,99 & 312.067 \\
0,47 & 848.495 & 0,98 & 698.468 & 1,49 & 503.989 & 2,00 & 308.538 \\
0,48 & 846.136 & 0,99 & 694.974 & 1,50 & 500.000 & 2,01 & 305.026 \\
0,49 & 843.752 & 1,00 & 691.462 & 1,51 & 496.011 & 2,02 & 301.532 \\
0,50 & 841.345 & 1,01 & 687.933 & 1,52 & 492.022 & 2,03 & 298.056 \\
\hline
\end{tabular}


Konversi DPMO ke Nilai Sigma Berdasarkan Konsep Motorola

\begin{tabular}{|c|c|c|c|c|c|c|c|}
\hline $\begin{array}{l}\text { Nilai } \\
\text { Sigma }\end{array}$ & DPMO & $\begin{array}{l}\text { Nilai } \\
\text { Sigma }\end{array}$ & DPMO & $\begin{array}{c}\text { Nilai } \\
\text { Sigma }\end{array}$ & DPMO & $\begin{array}{c}\text { Nilai } \\
\text { Sigma }\end{array}$ & DPMO \\
\hline 2,04 & 294.598 & 2,55 & 146.859 & 3,06 & 59.380 & 3,57 & 19.226 \\
\hline 2,05 & 291.160 & 2,56 & 144.572 & 3,07 & 58.208 & 3,58 & 18.763 \\
\hline 2,06 & 287.740 & 2,57 & 142.310 & 3,08 & 57.053 & 3,59 & 18.309 \\
\hline 2,07 & 284.339 & 2,58 & 140.071 & 3,09 & 55.917 & 3,60 & 17.864 \\
\hline 2,08 & 280.957 & 2,59 & 137.857 & 3,10 & 54.799 & 3,61 & 17.429 \\
\hline 2,09 & 277.595 & 2,60 & 135.666 & 3,11 & 53.699 & 3,62 & 17.003 \\
\hline 2,10 & 274.253 & 2,61 & 133.500 & 3,12 & 52.616 & 3,63 & 16.586 \\
\hline 2,11 & 270.931 & 2,62 & 131.357 & 3,13 & 51.551 & 3,64 & 16.177 \\
\hline 2,12 & 267.629 & 2,63 & 129.238 & 3,14 & 50.503 & 3,65 & 15.778 \\
\hline 2,13 & 264.347 & 2,64 & 127.143 & 3,15 & 49.471 & 3,66 & 15.386 \\
\hline 2,14 & 261.086 & 2,65 & 125.072 & 3,16 & 48.457 & 3,67 & 15.003 \\
\hline 2,15 & 257.846 & 2,66 & 123.024 & 3,17 & 47.460 & 3,68 & 14.629 \\
\hline 2,16 & 254.627 & 2,67 & 121.001 & 3,18 & 46.479 & 3,69 & 16.262 \\
\hline 2,17 & 251.429 & 2,68 & 119.000 & 3,19 & 45.514 & 3,70 & 13.903 \\
\hline 2,18 & 248.252 & 2,69 & 117.023 & 3,20 & 44.565 & 3,71 & 13.553 \\
\hline 2,19 & 245.097 & 2,70 & 115.070 & 3,21 & 43.633 & 3,72 & 13.209 \\
\hline 2,20 & 241.964 & 2,71 & 113.140 & 3,22 & 42.716 & 3,73 & 12.874 \\
\hline 2,21 & 238.852 & 2,72 & 111.233 & 3,23 & 41.815 & 3,74 & 12.545 \\
\hline 2,22 & 235.762 & 2,73 & 109.349 & 3,24 & 40.929 & 3,75 & 12.224 \\
\hline 2,23 & 232.695 & 2,74 & 107.488 & 3,25 & 40.059 & 3,76 & 11.911 \\
\hline 2,24 & 229.650 & 2,75 & 105.650 & 3,26 & 39.204 & 3,77 & 11.604 \\
\hline 2,25 & 226.627 & 2,76 & 103.835 & 3,27 & 38.364 & 3,78 & 11.304 \\
\hline 2,26 & 223.627 & 2,77 & 102.042 & 3,28 & 37.538 & 3,79 & 11.011 \\
\hline 2,27 & 220.650 & 2,78 & 100.273 & 3,29 & 36.727 & 3,80 & 10.724 \\
\hline 2,28 & 217.695 & 2,79 & 98.525 & 3,30 & 35.930 & 3,81 & 10.444 \\
\hline 2,29 & 214.764 & 2,80 & 96.801 & 3,31 & 35.148 & 3,82 & 10.170 \\
\hline 2,30 & 211.855 & 2,81 & 95.098 & 3,32 & 34.379 & 3,83 & 9.903 \\
\hline 2,31 & 208.970 & 2,82 & 93.418 & 3,33 & 33.625 & 3,84 & 9.642 \\
\hline 2,32 & 206.108 & 2,83 & 91.759 & 3,34 & 32.884 & 3,85 & 9.387 \\
\hline 2,33 & 203.269 & 2,84 & 90.123 & 3,35 & 32.157 & 3,86 & 9.137 \\
\hline 2,34 & 200.454 & 2,85 & 88.508 & 3,36 & 31.443 & 3,87 & 8.894 \\
\hline 2,35 & 197.662 & 2,86 & 86.915 & 3,37 & 30.742 & 3,88 & 8.656 \\
\hline 2,36 & 194.894 & 2,87 & 85.344 & 3,38 & 30.054 & 3,89 & 8.424 \\
\hline 2,37 & 192.150 & 2,88 & 83.793 & 3,39 & 29.379 & 3,90 & 8.198 \\
\hline 2,38 & 189.430 & 2,89 & 82.264 & 3,40 & 28.716 & 3,91 & 7.976 \\
\hline 2,39 & 186.733 & 2,90 & 80.757 & 3,41 & 28.067 & 3,92 & 7.760 \\
\hline 2,40 & 184.060 & 2,91 & 79.270 & 3,42 & 27.429 & 3,93 & 7.549 \\
\hline 2,41 & 181.411 & 2,92 & 77.804 & 3,43 & 26.803 & 3,94 & 7.344 \\
\hline 2,42 & 178.786 & 2,93 & 76.359 & 3,44 & 26.190 & 3,95 & 7.143 \\
\hline 2,43 & 176.186 & 2,94 & 74.934 & 3,45 & 25.588 & 3,96 & 6.947 \\
\hline 2,44 & 173.609 & 2,95 & 73.529 & 3,46 & 24.998 & 3,97 & 6.756 \\
\hline 2,45 & 171.056 & 2,96 & 72.145 & 3,47 & 24.419 & 3,98 & 6.569 \\
\hline 2,46 & 168.528 & 2,97 & 70.781 & 3,48 & 23.852 & 3,99 & 6.387 \\
\hline 2,47 & 166.023 & 2,98 & 69.437 & 3,49 & 23.295 & 4,00 & 6.210 \\
\hline
\end{tabular}


Konversi DPMO ke Nilai Sigma Berdasarkan Konsep Motorola

\begin{tabular}{|c|c|c|c|c|c|c|c|}
\hline $\begin{array}{c}\text { Nilai } \\
\text { Sigma }\end{array}$ & DPMO & $\begin{array}{c}\text { Nilai } \\
\text { Sigma }\end{array}$ & DPMO & $\begin{array}{c}\text { Nilai } \\
\text { Sigma }\end{array}$ & DPMO & $\begin{array}{c}\text { Nilai } \\
\text { Sigma }\end{array}$ & DPMO \\
\hline 2,48 & 163.543 & 2,99 & 68.112 & 3,50 & 22.750 & 4,01 & 6.037 \\
2,49 & 161.087 & 3,00 & 66.807 & 3,51 & 22.215 & 4,02 & 5.868 \\
2,50 & 158.655 & 3,01 & 65.522 & 3,52 & 21.692 & 4,03 & 5.703 \\
2,51 & 156.248 & 3,02 & 64.256 & 3,53 & 21.178 & 4,04 & 5.543 \\
2,52 & 153.864 & 3,03 & 63.008 & 3,54 & 20.675 & 4,05 & 5.386 \\
2,53 & 151.505 & 3,04 & 61.780 & 3,55 & 20.182 & 4,06 & 5.234 \\
2,54 & 149.170 & 3,05 & 60.571 & 3,56 & 19.699 & 4,07 & 5.085 \\
\hline
\end{tabular}


Konversi DPMO ke Nilai Sigma Berdasarkan Konsep Motorola

\begin{tabular}{|c|c|c|c|c|c|c|c|}
\hline $\begin{array}{l}\text { Nilai } \\
\text { Sigma }\end{array}$ & DPMO & $\begin{array}{l}\text { Nilai } \\
\text { Sigma }\end{array}$ & DPMO & $\begin{array}{l}\text { Nilai } \\
\text { Sigma }\end{array}$ & DPMO & $\begin{array}{l}\text { Nilai } \\
\text { Sigma }\end{array}$ & DPMO \\
\hline 4,08 & 4.940 & 4,59 & 1.001 & 5,10 & 159 & 5,61 & 20 \\
\hline 4,09 & 4.799 & 4,60 & 968 & 5,11 & 153 & 5,62 & 19 \\
\hline 4,10 & 4.661 & 4,61 & 936 & 5,12 & 147 & 5,63 & 18 \\
\hline 4,11 & 4.527 & 4,62 & 904 & 5,13 & 142 & 5,64 & 17 \\
\hline 4,12 & 4.397 & 4,63 & 874 & 5,14 & 136 & 5,65 & 17 \\
\hline 4,13 & 4.269 & 4,64 & 845 & 5,15 & 131 & 5,66 & 16 \\
\hline 4,14 & 4.145 & 4,65 & 816 & 5,16 & 126 & 5,67 & 15 \\
\hline 4,15 & 4.025 & 4,66 & 789 & 5,17 & 121 & 5,68 & 15 \\
\hline 4,16 & 3.907 & 4,67 & 762 & 5,18 & 117 & 5,69 & 14 \\
\hline 4,17 & 3.793 & 4,68 & 736 & 5,19 & 112 & 5,70 & 13 \\
\hline 4,18 & 3.681 & 4,69 & 711 & 5,20 & 108 & 5,71 & 13 \\
\hline 4,19 & 3.573 & 4,70 & 687 & 5,21 & 104 & 5,72 & 12 \\
\hline 4,20 & 3.467 & 4,71 & 664 & 5,22 & 100 & 5,73 & 12 \\
\hline 4,21 & 3.364 & 4,72 & 641 & 5,23 & 96 & 5,74 & 11 \\
\hline 4,22 & 3.264 & 4,73 & 619 & 5,24 & 92 & 5,75 & 11 \\
\hline 4,23 & 3.167 & 4,74 & 598 & 5,25 & 88 & 5,76 & 10 \\
\hline 4,24 & 3.072 & 4,75 & 577 & 5,26 & 85 & 5,77 & 10 \\
\hline 4,25 & 2.980 & 4,76 & 557 & 5,27 & 82 & 5,78 & 9 \\
\hline 4,26 & 2.890 & 4,77 & 538 & 5,28 & 78 & 5,79 & 9 \\
\hline 4,27 & 2.803 & 4,78 & 519 & 5,29 & 75 & 5,80 & 9 \\
\hline 4,28 & 2.718 & 4,79 & 501 & 5,30 & 72 & 5,81 & 8 \\
\hline 4,29 & 2.635 & 4,80 & 483 & 5,31 & 70 & 5,82 & 8 \\
\hline 4,30 & 2.555 & 4,81 & 467 & 5,32 & 67 & 5,83 & 7 \\
\hline 4,31 & 2.477 & 4,82 & 450 & 5,33 & 64 & 5,84 & 7 \\
\hline 4,32 & 2.401 & 4,83 & 434 & 5,34 & 62 & 5,85 & 7 \\
\hline 4,33 & 2.327 & 4,84 & 419 & 5,35 & 59 & 5,86 & 7 \\
\hline 4,34 & 2.256 & 4,85 & 404 & 5,36 & 57 & 5,87 & 6 \\
\hline 4,35 & 2.186 & 4,86 & 390 & 5,37 & 54 & 5,88 & 6 \\
\hline 4,36 & 2.118 & 4,87 & 376 & 5,38 & 52 & 5,89 & 6 \\
\hline 4,37 & 2.052 & 4,88 & 362 & 5,39 & 50 & 5,90 & 5 \\
\hline 4,38 & 1.988 & 4,89 & 350 & 5,40 & 48 & 5,91 & 5 \\
\hline 4,39 & 1.926 & 4,90 & 337 & 5,41 & 46 & 5,92 & 5 \\
\hline 4,40 & 1.866 & 4,91 & 325 & 5,42 & 44 & 5,93 & 5 \\
\hline 4,41 & 1.807 & 4,92 & 313 & 5,43 & 42 & 5,94 & 5 \\
\hline 4,42 & 1.750 & 4,93 & 302 & 5,44 & 41 & 5,95 & 4 \\
\hline 4,43 & 1.695 & 4,94 & 291 & 5,45 & 39 & 5,96 & 4 \\
\hline 4,44 & 1.641 & 4,95 & 280 & 5,46 & 37 & 5,97 & 4 \\
\hline 4,45 & 1.589 & 4,96 & 270 & 5,47 & 36 & 5,98 & 4 \\
\hline 4,46 & 1.538 & 4,97 & 260 & 5,48 & 34 & 5,99 & 4 \\
\hline 4,47 & 1.489 & 4,98 & 251 & 5,49 & 33 & 6,00 & 3 \\
\hline 4,48 & 1.441 & 4,99 & 242 & 5,50 & 32 & & \\
\hline 4,49 & 1.395 & 5,00 & 233 & 5,51 & 30 & & \\
\hline 4,50 & 1.350 & 5,01 & 224 & 5,52 & 29 & & \\
\hline 4,51 & 1.306 & 5,02 & 216 & 5,53 & 28 & & \\
\hline
\end{tabular}


Konversi DPMO ke Nilai Sigma Berdasarkan Konsep Motorola

\begin{tabular}{|c|c|c|c|c|c|c|c|}
\hline $\begin{array}{c}\text { Nilai } \\
\text { Sigma }\end{array}$ & DPMO & $\begin{array}{c}\text { Nilai } \\
\text { Sigma }\end{array}$ & DPMO & $\begin{array}{c}\text { Nilai } \\
\text { Sigma }\end{array}$ & DPMO & $\begin{array}{c}\text { Nilai } \\
\text { Sigma }\end{array}$ & DPMO \\
\hline 4,52 & 1.264 & 5,03 & 208 & 5,54 & 27 & & \\
4,53 & 1.223 & 5,04 & 200 & 5,55 & 26 & & \\
4,54 & 1.183 & 5,05 & 193 & 5,56 & 25 & & \\
4,55 & 1.144 & 5,06 & 185 & 5,57 & 24 & & \\
4,56 & 1.107 & 5,07 & 179 & 5,58 & 23 & & \\
4,57 & 1.070 & 5,08 & 172 & 5,59 & 22 & & \\
4,58 & 1.035 & 5,09 & 165 & 5,60 & 21 & & \\
\hline
\end{tabular}

Sumber: nilai-nilai dibangkitkan menggunakan program oleh: Vincent Gaspersz (2002) 